\author{
UNIVERSIDADE DE SÃO PAULO \\ FACULDADE DE CIÊNCIAS FARMACÊUTICAS \\ Programa de Pós-Graduação em Fármaco e Medicamentos \\ Área de Produção e Controle Farmacêuticos
}

\title{
Identificação de ácidos graxos presentes no óleo de Castanha do Brasil em emulsões cosméticas
}

\author{
CIBELE ROSANA RIBEIRO DE CASTRO LIMA
}

Dissertação apresentada para obtenção do grau de

Mestre

Orientadora:

Profạ. Titular Érika Rosa Maria Kedor-Hackmann

SÃO PAULO 


\author{
UNIVERSIDADE DE SÃO PAULO \\ FACULDADE DE CIÊNCIAS FARMACÊUTICAS \\ Programa de Pós-Graduação em Fármaco e Medicamentos \\ Área de Produção e Controle Farmacêuticos
}

\title{
Identificação de ácidos graxos presentes no óleo de Castanha do Brasil em emulsões cosméticas
}

\author{
CIBELE ROSANA RIBEIRO DE CASTRO LIMA
}

Dissertação apresentada para obtenção do grau de

Mestre

Orientadora:

Profạ. Titular Érika Rosa Maria Kedor-Hackmann

SÃO PAULO 
Cibele Rosana Ribeiro de Castro Lima

Identificação de ácidos graxos presentes no óleo de Castanha do Brasil em emulsões cosméticas

Comissão julgadora

DISSERTAÇÃO PARA OBTENÇÃO DO GRAU DE MESTRE

Prof ${ }^{a}$. Titular Érika Rosa Maria Kedor-Hackmann

Orientadora e presidente

$1^{\circ}$ Examinador

$2^{\circ}$ Examinador

São Paulo, de 
A Prof ${ }^{a}$ Dr ${ }^{a}$ Érika Rosa Maria Kedor-Hackmann, Pela orientação, disponibilidade, confiança, carinho e amizade. 


\section{Agradecimentos}

Ao Programa de Pós-Graduação em Ciências Farmacêuticas, pela grande oportunidade.

A empresa Belila Brasil, mais especialmente à Ana Cláudia Soares da Rocha, pelo apoio, incentivo, amizade e colaboração concedidos para que eu pudesse realizar este trabalho. Muito obrigada!!

A empresa Inovan do Brasil, pela gentileza de ceder amostras.

Aos queridos Professores Dr. Jivaldo do Rosário Matos e Dra Lucildes Pita Mercuri, pela ajuda, amizade e por ceder o laboratório para tantos experimentos.

À Prof ${ }^{a}$ Dra Maria Inês Rocha Miritello Santoro, pela ajuda, colaboração e amizade.

À Prof ${ }^{a}$ Dra María Segunda Aurora Prado, pelo apoio e amizade.

Ao Prof Dr. Jorge Mancini, por ceder o laboratório para a realização das análises de cromatografia em fase gasosa.

A' Rosângela Torres, pela ajuda e disponibilidade.

À querida Iria, pela amizade e ajuda e alegria.

Ao amigo, Pedro López, por todo o apoio, atenção e colaboração que me deu, acima de tudo, agradeço pela amizade e paciência.

À amiga Vanessa Franco Tavares, pela paciência, disponibilidade e grande ajuda para que este trabalho pudesse ser realizado. Amiga, muito obrigada de coração!!!!

À amiga Carolina, sempre pronta para ajudar e me ouvir! Obrigada pelas palavras de ânimo e conforto! Você mora no meu coração!!!

À amiga Mariana pela amizade desde o início dessa longa jornada. Amiga, você é especial!!

As amigas Alessandra, Aline, Carolina, Daniela, Mariana, Túlia e Vanessa pela grande ajuda, apoio, amizade e momentos de descontração. Muito obrigada!!! 
A' amiga Joyce pela amizade, apoio, pelos trabalhos em conjunto e pelas amostras concedidas.

A todos os amigos do laboratório de Controle físico-químico de qualidade de medicamentos e cosméticos pela contribuição, amizade e ajuda.

A todos aqueles que, direta ou indiretamente, foram prestativos, voluntários, compreensivos, mas acima de tudo, companheiros. 


\section{RESUMO}

LIMA, C.R.R.C. Identificação de ácidos graxos presentes no óleo de Castanha do Brasil em emulsões cosméticas. 2010. Dissertação (Mestrado) - Faculdade de Ciências Farmacêuticas, Universidade de São Paulo, São Paulo, 2010.

As buscas de novas substâncias ativas com finalidades cosméticas e dermatológicas e as elucidações científicas dos reais benefícios a elas atribuídos têm sido uma exigência do mercado consumidor. Atualmente vários produtos cosméticos contendo óleos naturais da Amazônia têm sido desenvolvidos e estão disponíveis no mercado, causando uma grande revolução na indústria de cosméticos. Esses óleos apresentam grande concentração de ácidos graxos, que são compostos capazes de melhorar a barreira transepidérmica, apresentando-se como substâncias funcionais na hidratação da pele. O presente trabalho teve como principal objetivo o desenvolvimento de uma metodologia analítica por eletroforese capilar para a identificação de ácidos graxos presentes no óleo de Castanha do Brasil em emulsões cosméticas. Primeiramente, este óleo foi caracterizado isoladamente quanto aos ácidos graxos nele presentes pelos métodos de cromatografia em fase gasosa (CG) e cromatografia em fase líquida de alta eficiência (CLAE). Foi desenvolvida uma formulação para a incorporação deste óleo e realizou-se um estudo de estabilidade física desta formulação. As características físicas e organolépticas do estudo em questão foram obtidas. Os ácidos graxos encontrados no óleo de Castanha do Brasil foram os ácidos linoléico, oléico, palmítico, esteárico e outros em menor proporção. Para a determinação da estabilidade térmica do óleo de Castanha do Brasil e das formulações cosméticas foi utilizado a termogravimetria/termogravimetria derivada. As formulações submetidas ao estudo de estabilidade acelerada se mantiveram estáveis, sem alterações de suas características físicas e organolépticas. Foi desenvolvido um método por eletroforese capilar, aplicando a técnica de Cromatografia Eletrocinética em Microemulsão, para a determinação dos ácidos graxos presentes no óleo de Castanha do Brasil nas formulações cosméticas desenvolvidas. Este método apresentou-se como ferramenta viável no controle de qualidade de matérias-primas em cosméticos.

Palavras-chave: Óleo de Castanha do Brasil. Ácidos graxos. Identificação. 


\begin{abstract}
LIMA, C.R.R.C. Identification of fatty acids containing in the Brazil nut oil in cosmetics emulsions. 2010. Dissertação (Mestrado) - Faculdade de Ciências Farmacêuticas, Universidade de São Paulo, São Paulo, 2010.
\end{abstract}

The search for new active ingredients with skin and cosmetic purposes and the scientific elucidation of the actual benefits assigned to them have been demanding consumer market. Currently many cosmetic products containing Amazon natural oils have been developed and are available on the market, causing a major revolution in the cosmetics industry. These oils have high concentrations of fatty acids, which are compounds that can enhance the transepidermal barrier, presenting as functional substances in skin hydration. This work had as main aim the developed of an analytical method by capillary electrophoresis for the determination of fatty acids contain in Brazil nut oil in cosmetics emulsions.First, the Brazil nut oil was characterized for the fatty acids contain by Gas Chromatography (GC) and High Performance Liquid Chromatography (HPLC). To determinate the thermal stability of Brazil nut oil and the cosmetics formulations was used thermogrametry/derivative thermogravimetry. It was developed a formulation for the incorporation of Brazil nut oil and performed a study of physical stability of this formulation. The physical and organoleptic characteristics of the study were obtained. The fatty acids found in oil were linoleic, oleic, palmitic, stearic acids and another in smaller amount. A thermoanalytical method for the stability evaluation of fatty acids present in Brazil nut oil as raw material and in cosmetic formulations was also developed. Formulations subjected to accelerated stability study remained stable, with no changes in their physical and organoleptic characteristics. It was developed a capillary electrophoresis method, applying the technique in Microemulsion Electrokinetic Chromatography for the determination of fatty acids in Brazil nut oil in cosmetic formulations developed. This method showed as a viable tool in quality control of raw materials in cosmetics.

Key-words: Brazil nut oil. Fatty acids. Identification. 


\section{SUMÁRIO}

1. INTRODUÇÃO

2. REVISÃO DA LITERATURA....................................................................

2.1. Estrutura da pele e de seus anexos.............................................. 3

2.2. Composição química da pele......................................................... 4

2.3. Aspectos fisiológicos da pele.......................................................... 4

2.4. O envelhecimento cutâneo......................................................... 5

2.4.1. A hidratação na proteção ao envelhecimento cutâneo....... 7

2.5. Cosméticos................................................................................. 9

2.5.1. Emulsões............................................................ 9

2.5.2. Matérias-primas utilizadas em emulsões cosméticas......... 10

2.5.3. Formulações gel-creme.................................................. 12

2.5.4. Estabilidade de emulsões.............................................. 12

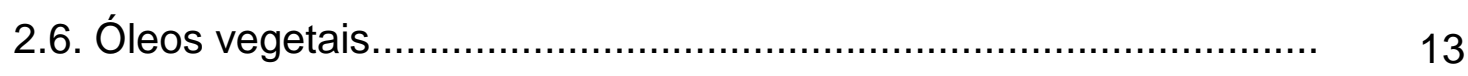

2.6.1. Generalidades............................................................. 13

2.6.2. Óleos vegetais e aplicação cosmética................................ 14

2.6.3. Castanha do Brasil ...................................................... 16

2.6.3.1. Óleo de Castanha do Brasil.................................. 17

2.6.3.2. Extração do óleo de Castanha do Brasil.............. 19

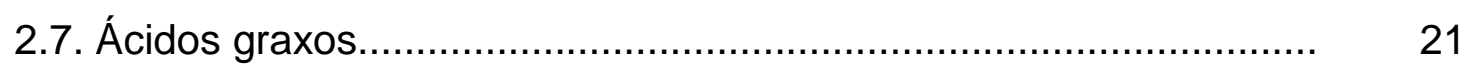

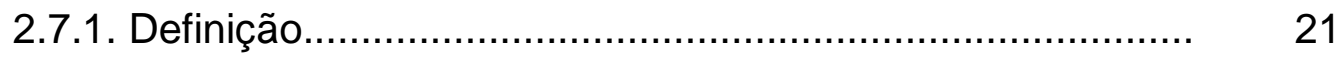

2.7.2. Estrutura dos ácidos graxos........................................... 22

2.7.3. Ácidos graxos presentes no óleo de Castanha do Brasil... 23

2.7.4. Reação de hidrólise de ésteres promovida por base 26

2.7.5. Técnicas empregadas na caracterização dos ácidos graxos.

2.7.5.1. Análise Térmica............................................... 27

2.7.5.2. Estudo da Estabilidade de produtos cosméticos... $\quad 30$

2.7.5.2.1. Teste de centrifugação.......................... 31

2.7.5.2.2. Estudo da Estabilidade acelerada......... 31

2.7.5.3. Cromatografia em fase gasosa (CG)...................... 32

2.7.5.3.1. Análise de ácidos graxos por Cromatografia 
em fase gasosa.

2.7.5.4. Cromatografia em fase líquida de alta eficiência (CLAE)

2.7.5.4.1. Análise de ácidos graxos por Cromatografia em fase gasosa. 35

2.7.5.5. Eletroforese capilar (EC). 36

2.7.5.5.1. Princípios da eletroforese capilar. 38

2.7.5.5.2. Fluxo eletrosmótico. 38

2.7.5.5.3. Técnicas de eletroforese capilar. 40

2.7.5.5.4. Análise de ácidos graxos por Eletroforese capilar.

3. OBJETIVOS. 44

4. MATERIAL E MÉTODOS.

4.1. MATERIAL

4.1.1. Matérias-primas empregadas no desenvolvimento das formulações. 45

4.1.1.1. Umectante. 45

4.1.1.2. Emulsionante polimérico. 45

4.1.1.3. Tensoativo não iônico hidrossolúvel. 45

4.1.1.4. Quelante 46

4.1.1.5. Conservante 46

4.1.1.6. Veículo. 47

4.1.1.7. Emolientes 47

4.1.1.8. Antioxidante. 49

4.1.2. Amostras. 50

4.1.3. Solventes, soluções e reagentes. 50

4.1.4. Substâncias empregadas como substâncias químicas de referência de grau cromatográfico. 51

4.1.5. Consumíveis. 51

4.1.6. Equipamentos. 51

4.2. MÉTODOS 52

4.2.1. Caracterização da matéria-prima. 
4.2.1.1. Cromatografia em fase gasosa (CG) .............................. 53

4.2.1.1.1. Preparo da solução de ácidos graxos................. 53

4.2.1.1.2. Condições empregadas no ensaio....................... 53

4.2.1.2. Cromatografia em fase líquida de alta eficiência (CLAE)

4.2.1.2.1. Preparo da solução de ácidos graxos padrões

4.2.1.2.2. Extração dos ácidos graxos no óleo de Castanha do Brasil para análise em cromatografia em fase líquida de alta eficiência

4.2.1.2.3. Saponificação de ácidos graxos para análise em cromatografia em fase líquida de alta eficiência.

4.2.1.2.4. Derivatização com bromometil-metóxi-coumarina (BrMMC) para a formação de um complexo fluorescente

4.2.1.2.5. Condições empregadas no ensaio........................ 55

4.2.1.3. Eletroforese capilar (EC) ..................................... 56

4.2.1.3.1. Desenvolvimento analítico.................................... 56

4.2.1.3.1.1. Preparo do eletrólito...................................... 57

4.2.1.3.1.2. Soluções dos ácidos graxos......................... 57

4.2.1.3.1.3. Definição dos parâmetros eletroforéticos..... 58

4.2.1.3.1.4. Condições do equipamento.......................... 58

4.2.1.3.1.5. Parâmetros experimentais otimizados............ 58

4.3. Preparação da formulação cosmética desenvolvida........................... 59

4.4. Preparação das amostras das formulações cosméticas para análise em Eletroforese capilar..................................................................... 59

4.4.1. Extração da fase oleosa das amostras das formulações desenvolvidas.

4.4.2. Saponificação da fase oleosa extraída das formulações desenvolvidas. 59

4.4.3. Saponificação das matérias-primas...................................... 60

4.5. Saponificação do óleo de Castanha do Brasil..................................... 60

4.6. Estudo de estabilidade das formulações cosméticas........................... 61 
4.6.1. Teste de centrifugação....................................................... 61

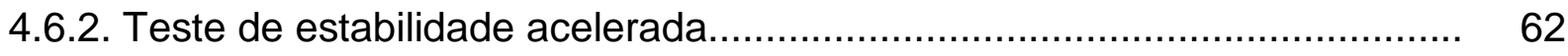

4.6.3. Avaliação das formulações cosméticas............................... 62

4.6.4. Determinação do tipo de emulsão....................................... 63

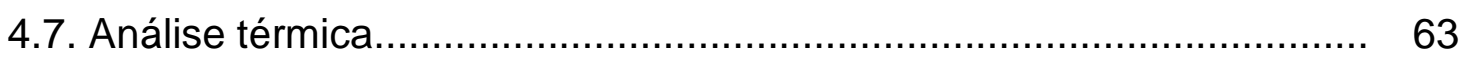

4.7.1. Termogravimetria/Termogravimetria derivada (TG/DTG) ... 63

4.7.2. Calorimetria Exploratória Diferencial (DSC)......................... 63

4.7.3. Estudo cinético do óleo de Castanha do Brasil por

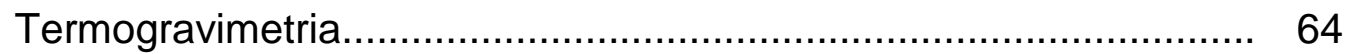

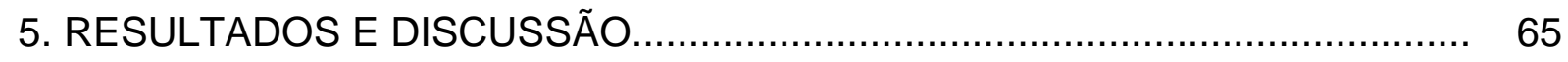

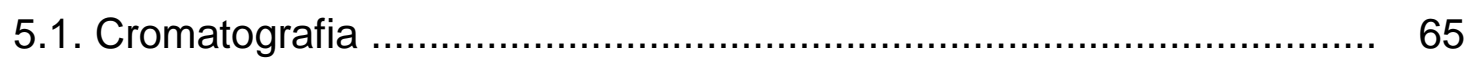

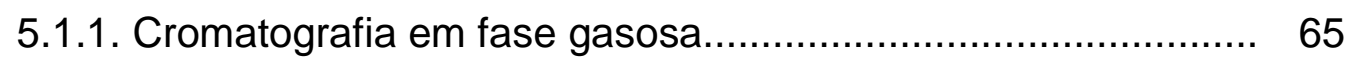

5.1.2. Cromatografia em fase líquida de alta eficiência (CLAE)...... 68

5.2. Eletroforese capilar (EC) ...................................................... 70

5.2.1. Escolha do tipo de eletroforese.......................................... 70

5.2.2. Seleção do capilar.............................................................. 71

5.2.3. Seleção do $\mathrm{pH}$ do eletrólito................................................. 71

5.2.4. Seleção do cromóforo...................................................... 72

5.2.5. Influência de solventes orgânicos....................................... 72

5.2.6. Tempo injeção da amostra................................................... 73

5.2.7. Determinação da voltagem................................................ 75

5.2.8. Pré-tratamento da amostra................................................ 76

5.2.9. Pré-condicionamento do capilar......................................... 76

5.2.10. Utilização do eletrólito - Reposição................................... 77

5.2.11. Estudo de interferentes no placebo da formulação

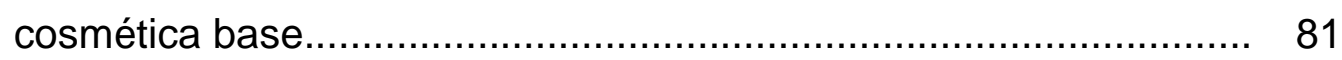

5.2.12. Considerações a respeito de parâmetros do processo de validação do método desenvolvido por eletroforese capilar........... 82

5.3. Estudo de estabilidade das formulações cosméticas.......................... 87

5.3.1. Teste de estabilidade preliminar......................................... 87

5.3.2. Determinação do tipo de emulsão......................................... 88

5.3.3. Teste de estabilidade acelerada........................................... 88 
5.4. Análise térmica .................................................................... 92

5.4.1. Óleo de Castanha do Brasil................................................ 92

5.4.2. Formulações cosméticas.................................................... 93

5.4.3. Estudo cinético do óleo de Castanha do Brasil por termogravimetria pelo método isotérmico..................................... 94

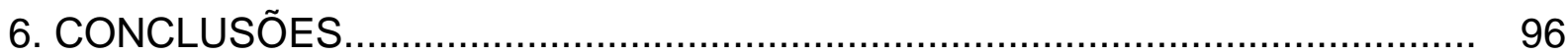

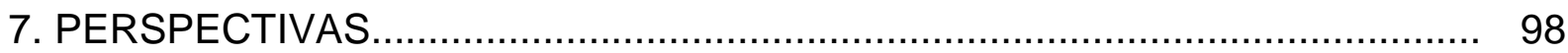

8. REFERÊNCIAS BIBLIOGRÁFICAS........................................... 99

ANEXOS 


\section{LISTA DE FIGURAS}

Figura 1: Camadas da pele e estrutura da epiderme.

(Fonte:www.bioderma.fr/conceils/informations.asp).

Figura 2: (a) Ouriço da castanha do Brasil sem as sementes (www.brazilianbeauty.org.br) (b) Corte transversal do ouriço da Castanha do Brasil com as sementes (foto tirada em out/2007)......

Figura 3: Estrutura do ácido oléico (w9) (ROSE et al., 1999)............................... 24

Figura 4: Estrutura do ácido linoléico (w6) (ROSE et al., 1999)............................. 25

Figura 5: Esquema da reação de hidrólise dos glicerídeos (Fonte: Morrison \& Boyd)

Figura 6: Representação fotográfica da termobalança modelo TGA 50 (SHIMADZU, 2004) e esquema da estrutura de colocação do porta-amostra.........

Figura 7: Esquema da reação de derivatização com BrMMC na presença do éter de coroa.

Figura 8: Configuração Básica do sistema de Eletroforese Capilar.

Figura 9: Esquema mostrando a formação e o sentido do fluxo eletro-osmótico (fonte: QUEIROZ; JARDIM, 2005).

Figura 10: llustração fotográfica do sistema utilizado para as reações de saponificação das amostras.

Figura 11: Cromatograma da mistura padrão de ésteres metílicos de ácidos graxos. Condições cromatográficas: Coluna de sílica fundida Supelcowax 10 de $30 \mathrm{~m}$ e $0,25 \mathrm{~mm}$ de d.i.; Temperatura programada da coluna: aquecimento a 1 ${ }^{\circ} \mathrm{C} /$ min de $1700^{\circ} \mathrm{C}$ até $22^{\circ} \mathrm{C}$, permanecendo nesta tempe ratura por 10 minutos; Temperatura do vaporizador: $250^{\circ} \mathrm{C}$; Temperatura do d etetor: $270{ }^{\circ} \mathrm{C}$; Gás de arraste: Hélio; Detector de ionização de chama; Velocidade linear do gás de arraste: $1 \mathrm{~mL} / \mathrm{min}$; Razão de divisão da amostra: 1:50; equipamento cromatógrafo á gás CG 17 A Shimadzu/Class CG 10.

Figura 12: Cromatograma dos ésteres metílicos de ácidos graxos do óleo de Castanha do Brasil. Condições cromatográficas: Coluna de sílica fundida Supelcowax 10 de $30 \mathrm{~m}$ e 0,25 mm de d.i.; Temperatura programada da coluna: aquecimento a $1^{\circ} \mathrm{C} / \mathrm{min}$ de $170^{\circ} \mathrm{C}$ até $2^{2} 5^{\circ} \mathrm{C}$, permanec endo nesta temperatura por 10 minutos; Temperatura do vaporizador: $250^{\circ} \mathrm{C}$; Temperatura do detetor: 270 `C; Gás de arraste: Hélio; Detector de ionizaçã o de chama; Velocidade linear do gás de arraste: $1 \mathrm{~mL} / \mathrm{min}$; Razão de divisão da amostra: 1:50; equipamento cromatógrafo á gás CG 17 A Shimadzu/Class CG 10 
Figura 13: Cromatograma da mistura padrão de ácidos graxos. Condições cromatográficas: coluna de fase reversa Shim-pack CLC-C $84,6 \mathrm{~mm}$ i.d. x $25 \mathrm{~cm}$ com partículas de $5 \mu \mathrm{m}$, precedidas de pré-coluna (Shim-pack G-ODS 8,0 mm i.d.x 1,5 cm); fase móvel ACN:Água (73:23); vazão $0,5 \mathrm{~mL} / \mathrm{min}$; volume de injeção $40 \mu \mathrm{L}$; detector de fluorescência; temperatura ambiente $\pm 25^{\circ} \mathrm{C}$;

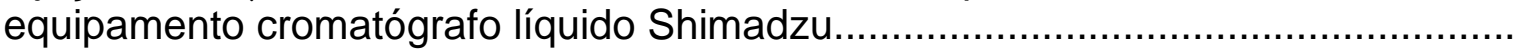

Figura 14: Cromatograma dos ácidos graxos do óleo de Castanha do Brasil. Condições cromatográficas: coluna de fase reversa Shim-pack CLC-C ${ }_{8} 4,6 \mathrm{~mm}$ i.d. $\times 25 \mathrm{~cm}$ com partículas de $5 \mu \mathrm{m}$, precedidas de pré-coluna (Shim-pack GODS $8,0 \mathrm{~mm}$ i.d.x 1,5 cm); fase móvel $A C N$ :Água (73:23); vazão $0,5 \mathrm{~mL} / \mathrm{min}$; volume de injeção $40 \mu \mathrm{L}$; detector de fluorescência; temperatura ambiente \pm ${ }^{2} 5^{\circ} \mathrm{C}$; equipamento cromatógrafo líquido Shimadzu............................................

Figura 15: Eletroferograma da separação de uma mistura padrão de ácidos graxos dissolvidos em metanol $\left(0,25 \mathrm{mmol} \mathrm{L}^{-1}\right)$ : (1) esteárico, (2) oléico, (3) palmítico e (4) linoléico, utilizando como eletrólito $12,5 \mathrm{mmol} / \mathrm{L}$ de tetraborato de sódio $\mathrm{pH}$ 7,0; 35\% (v/v) ACN; $12,5 \mathrm{mmol} / \mathrm{L}$ Brij 35; 7,5 mmol/L SDBS. Capilar de $62 \mathrm{~cm}(50,2 \mathrm{~cm}$ até $o$ detector) e $75 \mu \mathrm{m}$ de d.i. (a) Voltagem aplicada: $+25 \mathrm{kV}$. Injeção hidrodinâmica 0,5 psi por $6 \mathrm{~s}, 25^{\circ} \mathrm{C}$. (b) Voltagem aplicada: +20 kV. Injeção hidrodinâmica 0,5 psi por $6 \mathrm{~s}, 25^{\circ} \mathrm{C}$

Figura 16. Eletroferograma da separação de uma mistura padrão de ácidos graxos dissolvidos em metanol: (1) esteárico, (2) oléico, (3) palmítico e (4) linoléico, utilizando como eletrólito $12,5 \mathrm{mmol} \mathrm{L}^{-1}$ de tetraborato de sódio $\mathrm{pH} 7,0$; $35 \%$ (v/v) ACN; $12,5 \mathrm{mmol} \mathrm{L}^{-1}$ Brij 35; 7,5 mmol L-1 SDBS. Capilar de $62 \mathrm{~cm}(50$ $\mathrm{cm}$ até o detector) e $75 \mu \mathrm{m}$ de d.i. (a) Voltagem aplicada: $+25 \mathrm{kV}$. Injeção hidrodinâmica 0,5 psi por $3 \mathrm{~s}, 25^{\circ} \mathrm{C}$. (b) Voltagem aplicada: $+25 \mathrm{kV}$. Injeção hidrodinâmica 0,3 psi por $3 \mathrm{~s}, 25^{\circ} \mathrm{C}$. Concentração de cada ácido graxo: $250,0 \mu \mathrm{g}$ $\mathrm{mL}^{-1}$.

Figura 17: Eletroferograma da separação de uma mistura padrão de ácidos graxos dissolvidos em metanol $\left(0,25 \mathrm{mmol} \mathrm{L}^{-1}\right)$ : (1) esteárico, (2) oléico, (3) palmítico e (4) linoléico, utilizando como eletrólito $12,5 \mathrm{mmol} / \mathrm{L}$ de tetraborato de sódio $\mathrm{pH}$ 7,0; 35\% (v/v) ACN; $12,5 \mathrm{mmol} / \mathrm{L}$ Brij 35; 7,5 mmol/L SDBS. Capilar de $62 \mathrm{~cm}(50,2 \mathrm{~cm}$ até o detector) e $75 \mu \mathrm{m}$ de d.i. (a) Voltagem aplicada: $+20 \mathrm{kV}$. Injeção hidrodinâmica 0,5 psi por $6 \mathrm{~s}, 25^{\circ} \mathrm{C}$. (b) Voltagem aplicada: $+20 \mathrm{kV}$. Injeção hidrodinâmica 0,5 psi por $3 \mathrm{~s}, 25^{\circ} \mathrm{C}$

Figura 18: Eletroferograma da separação de uma mistura padrão de ácidos graxos dissolvidos em metanol $\left(0,25 \mathrm{mmol} \mathrm{L}^{-1}\right)$ : (1) esteárico, (2) margárico (padrão interno), (3) oléico e (4) palmítico, (5) linoléico e (6) linolênico, utilizando como eletrólito 12,5 mmol/L de tetraborato de sódio $\mathrm{pH} \mathrm{7,0;35 \%} \mathrm{(v/v)} \mathrm{ACN;} 12,5$ $\mathrm{mmol} / \mathrm{L}$ Brij 35; 7,5 mmol/L SDBS. Capilar de $62 \mathrm{~cm}$ (50,2 cm até o detector) e 75 $\mu \mathrm{m}$ de d.i. Voltagem aplicada: +20 kV. Injeção hidrodinâmica 0,3 psi por 3s, $25^{\circ} \mathrm{C}$.

Figura 19: Eletroferograma dos ácidos graxos encontrados no óleo de Castanha do Brasil extra-virgem (1) esteárico, (2) margárico (padrão interno), (3) oléico e 
(4) palmítico e (5) linoléico, utilizando como eletrólito $12,5 \mathrm{mmol} / \mathrm{L}$ de tetraborato de sódio $\mathrm{pH} 7,0 ; 35 \%(\mathrm{v} / \mathrm{v})$ acetonitrila; $12,5 \mathrm{mmol} / \mathrm{L}$ Brij $35 ; 7,5 \mathrm{mmol} / \mathrm{L}$ SDBS. Capilar de $62 \mathrm{~cm}$ (50,2 cm até o detector) e $75 \mu \mathrm{m}$ de d.i. Voltagem aplicada: +20 kV. Injeção hidrodinâmica 0,3 psi por 3s, 25ํ․

Figura 20: Eletroferograma da separação dos ácidos graxos (1) esteárico, (2) oléico e (3) palmítico e (4) linoléico identificados na fase oleosa extraída da formulação cosmética contendo o óleo de Castanha do Brasil desenvolvida utilizando como eletrólito $12,5 \mathrm{mmol} / \mathrm{L}$ de tetraborato de sódio $\mathrm{pH} \mathrm{7,0;35 \%} \mathrm{(v/v)}$ ACN; $12,5 \mathrm{mmol} / \mathrm{L}$ Brij $35 ; 7,5 \mathrm{mmol} / \mathrm{L}$ SDBS. Capilar de $62 \mathrm{~cm}(50,2 \mathrm{~cm}$ até o detector) e $75 \mu \mathrm{m}$ de d.i. Potencial aplicado: $+20 \mathrm{kV}$. Injeção hidrodinâmica 0,3 psi por $3 \mathrm{~s}, 25^{\circ} \mathrm{C}$.

Figura 21: Eletroferograma da fase oleosa extraída da formulação placebo desenvolvida utilizando como eletrólito $12,5 \mathrm{mmol} / \mathrm{L}$ de tetraborato de sódio $\mathrm{pH}$ 7,0; 35\% (v/v) ACN; 12,5 mmol/L Brij 35; 7,5 mmol/L SDBS. Capilar de $62 \mathrm{~cm}$ $(50,2 \mathrm{~cm}$ até 0 detector) e $75 \mu \mathrm{m}$ de d.i. Voltagem aplicada: $+20 \mathrm{kV}$. Injeção hidrodinâmica 0,3 psi por $3 s, 25^{\circ} \mathrm{C}$.

Figura 22: Eletroferograma do Procetyl AWS, Sepigel 305, Phenova e triglicerídeos do ácido cáprico/ caprílico; utilizando como eletrólito $12,5 \mathrm{mmol} / \mathrm{L}$ de tetraborato de sódio $\mathrm{pH} \mathrm{7,0;35 \%} \mathrm{(v/v)} \mathrm{ACN;} 12,5 \mathrm{mmol} / \mathrm{L}$ Brij 35; 7,5 mmol/L SDBS. Capilar de $62 \mathrm{~cm}(50,2 \mathrm{~cm}$ até o detector) e $75 \mu \mathrm{m}$ de d.i. Potencial aplicado: +20 kV. Injeção hidrodinâmica 0,3 psi por $3 s, 25^{\circ} \mathrm{C}$

Figura 23: Eletroferogramas: (a) amostra comercial (creme hidratante); (b) mistura dos padrões dos ácidos graxos $\left(250,0 \mu \mathrm{g} \mathrm{mL}^{-1}\right)$ : (1) esteárico, (2) oléico e (3) palmítico e (4) linoléico, da utilizando como eletrólito $12,5 \mathrm{mmol} / \mathrm{L}$ de tetraborato de sódio $\mathrm{pH} 7,0 ; 35 \%$ (v/v) ACN; $12,5 \mathrm{mmol} / \mathrm{L}$ Brij 35; 7,5 mmol/L SDBS. Capilar de $62 \mathrm{~cm}(50,2 \mathrm{~cm}$ até 0 detector) e $75 \mu \mathrm{m}$ de d.i. Voltagem aplicada: $+20 \mathrm{kV}$. Injeção hidrodinâmica 0,3 psi por $3 \mathrm{~s}, 25^{\circ} \mathrm{C}$

Figura 24: Eletroferograma de dez injeções consecutivas da separação de uma mistura padrão de ácidos graxos dissolvidos em metanol $\left(0,25 \mathrm{mmol} \mathrm{L}^{-1}\right)$ : (1) esteárico, (2) margárico (padrão interno), (3) oléico e (4) palmítico, (5) linoléico e (6) linolênico, utilizando como eletrólito $12,5 \mathrm{mmol} / \mathrm{L}$ de tetraborato de sódio $\mathrm{pH}$ 7,0; 35\% (v/v) ACN; $12,5 \mathrm{mmol} / \mathrm{L}$ Brij 35; $7,5 \mathrm{mmol} / \mathrm{L}$ SDBS. Capilar de $62 \mathrm{~cm}$ (50,2 $\mathrm{cm}$ até o detector) e $75 \mu \mathrm{m}$ de d.i. Voltagem aplicada: $+20 \mathrm{kV}$. Injeção hidrodinâmica 0,3 psi por $3 s, 25^{\circ} \mathrm{C}$.

Figura 25: Eletroferograma de três injeções consecutivas de uma mistura padrão dos ácidos graxos na concentração de $0,25 \mathrm{mmol} \mathrm{L}^{-1}$ cada: (1) esteárico, (2) margárico, (3) oléico, (4) palmítico (5) linoléico e (6) linolênico, utilizando como eletrólito $12,5 \mathrm{mmol} / \mathrm{L}$ de tetraborato de sódio $\mathrm{pH} 7,0 ; 35 \%(\mathrm{v} / \mathrm{v}) \mathrm{ACN} ; 12,5$ $\mathrm{mmol} / \mathrm{L}$ Brij 35; 7,5 mmol/L SDBS. Capilar de $62 \mathrm{~cm}$ (50,2 cm até o detector) e 75 $\mu \mathrm{m}$ de d.i. Voltagem aplicada: $+20 \mathrm{kV}$. Injeção hidrodinâmica 0,3 psi por $3 \mathrm{~s}, 25^{\circ} \mathrm{C}$ de temperatura. 
Figura 26: Formulações após o teste de estabilidade preliminar (centrifugação a 3000 rpm durante 30 minutos).

Figura 27: Formulações no teste de estabilidade acelerada: Ciclos de congelamento $5^{\circ} \mathrm{C} /$ descongelamento $45^{\circ} \mathrm{C}$, geladeira à $5^{\circ} \mathrm{C}$, temperatura ambiente, estufa à $45^{\circ} \mathrm{C}$ e radiação solar).

Figura 28: Variação percentual do valor de pH do gel-creme placebo.

Figura 29: Variação percentual do valor de $\mathrm{pH}$ do gel-creme contendo o óleo de Castanha do Brasil.

Figura 30: Variação percentual do valor de viscosidade aparente do gel-creme Placebo.

Figura 31: Variação percentual do valor de viscosidade aparente do gel-creme placebo

Figura 32: Curvas TG/DTG e DSC do óleo de Castanha do Brasil obtidas a $10^{\circ} \mathrm{C}$ $\mathrm{min}^{-1}$, sob atmosfera dinâmica de ar sintético (TG/DTG) e $\mathrm{N}_{2}$ (DSC).

Figura 33: Curvas a) TG e b) DTG do creme gel e do creme gel associado ao óleo de Castanha do Brasil obtidas a $10^{\circ} \mathrm{C} \cdot \mathrm{min}^{-1}$, sob atmosfera dinâmica de ar sintético

Figura 34: Sobreposição das curvas TG do óleo de Castanha do Brasil a diferentes isotermas de temperaturas em atmosfera de ar

Figura 35: Gráfico InK $\left(\mathrm{min}^{-1}\right)$ VS. 1/T $\left(\mathrm{K}^{-1}\right)$ e equação da reta. 


\section{LISTA DE TABELAS}

Tabela 1: Características físico-químicas do óleo de Castanha do Brasil..........

Tabela 2: Composição da fração insaponificável do óleo de Castanha do Brasil segundo Gomes et al. (1997).....

Tabela 3: Ponto de fusão de alguns isômeros de ácidos graxos segundo Gunstone \& Norris, 1983

Tabela 4: Composição de ácidos graxos do óleo da Castanha do Brasil estudados por diferentes autores, analisados pelos métodos de cromatografia em fase gasosa.

Tabela 5: Concentração de ácidos graxos presentes na Castanha do Brasil obtida pelo método de Eletroforese Capilar obtida por Moraes (2004)

Tabela 6: Matérias-primas utilizadas na obtenção da formulação

Tabela 7: Tempo de retenção e composição dos ácidos graxos do óleo de Castanha do Brasil identificados como ésteres metílicos dos ácidos graxos obtidos do cromatograma da figura 13

Tabela 8: Áreas dos picos e composição em ácidos graxos do óleo de Castanha do Brasil identificados pelo método de cromatografia em fase líquida de alta eficiência.

Tabela 9: Resultados das médias, desvio padrão e C.V. para as áreas individuais dos ácidos graxos de dez injeções consecutivas utilizando o padrão interno (C17).

Tabela 10: Resultados das médias, desvio padrão e C.V. para os tempos individuais dos ácidos graxos de dez injeções consecutivas utilizando padrão interno (ácido margárico - C17:0)

Tabela 11: Avaliação das características organolépticas (aspecto, cor e odor), valores de $\mathrm{pH}$, viscosidade aparente do creme-gel placebo submetido ao teste de estabilidade acelerada.

Tabela 12: Avaliação das características organolépticas (aspecto, cor e odor), valores de $\mathrm{pH}$, viscosidade aparente do creme-gel contendo óleo de Castanha do Brasil submetido ao teste de estabilidade acelerada. 


\section{LISTA DE ABREVIATURAS E SÍMBOLOS}

ACN - acetonitrila

A/O - água em óleo

AG - Ácido graxo

AHAs - alfa hidroxiácidos

ANVISA - Agência Nacional de Vigilância Sanitária

$\mathrm{BHT}$ - butilhidroxitolueno

CG - cromatografia gasosa

CLAE - Cromatografia Líquida de Alta Eficiência

cm - centímetro

CZE - eletroforese capilar de zona

DHA - araquidônico

EPA - docosaexaenóico

FEO - Fluxo eletrosmótico

FDA - Food Drug Administration

FSCE - eletroforese capilar em solução livre

GRAS - Generally Recognized As Safe

mg - miligrama

$\mu g$ - micrograma

$\mathrm{mL}$ - mililitro

P.A. - para análise

rpm - rotações por minuto

UR - umidade relativa

UV - ultravioleta

O/A - óleo em água

FAME - Fatty acid metyl ester

MUFA - monoinsaturated fatty acid

MEKC - cromatografia capilar eletrocinética micelar

PUFA - polyunsaturated fatty acid

SAFA - satured fatty acid

UR - umidade relativa 


\section{INTRODUÇÃO}

A pele é o maior órgão do corpo humano e um dos mais complexos, sendo sua principal função atuar como barreira protetora do organismo contra agressões do meio externo. Além de possuir também importante papel na auto-estima, nas relações sociais e na qualidade de vida do ser humano. Possuindo uma aparência jovial, saudável e bonita, nos sentimos mais confiantes e seguros para enfrentar a vida cotidiana e também sermos mais bem aceitos por toda a sociedade (GARCIA, 1998; ROBERT, 1994).

A Ciência tem evoluído de maneira a prevenir o envelhecimento precoce e, até mesmo, retardar o envelhecimento fisiológico, tanto pela utilização de produtos cosméticos com funções de umectação e regeneração celular, bem como pelo emprego da terapia ortomolecular e técnicas avançadas utilizando-se de tecnologias específicas como, por exemplo, o laser (STEINER, 1995).

Nos últimos anos tem se observado uma tendência cada vez maior de uso de matérias-primas de origem natural em produtos farmacêuticos e cosméticos. Isto tem causado uma corrida aos óleos extraídos de plantas nativas da Amazônia, causando uma expansão rápida e significativa do mercado nacional e internacional destes produtos (FERREIRA et al., 2005).

Considerando a natureza complexa dessas matrizes, metodologias bem desenvolvidas para o controle de qualidade durante o processamento industrial dos extratos e seu armazenamento, bem como para acompanhar adulterações em materiais brutos e produtos finais são altamente desejáveis e a normalização de procedimentos de controle de qualidade tem sido recentemente o foco da legislação (TOMÁS-BARBERÁN, 1995).

Cromatografia em fase líquida (CLAE) e / ou cromatografia em fase gasosa (GC-FID, CGEM) são as técnicas que foram escolhidas para esse estudo. Eletroforese capilar tem sido considerada uma alternativa adequada para a análise de avaliação de diferentes classes de compostos que ocorrem naturalmente em extratos de plantas medicinais e óleos essenciais (TOMÁS-BARBERÁN, 1995). A espectroscopia de ressonância magnética nuclear é utilizada como uma técnica padrão e aplicada em estudo de lipídeos (SACCHI et al., 1997).

O óleo de Castanha do Brasil (Bertholletia Escelsa) é um produto rico em ácidos graxos (CAMPOS, 2007), que são substâncias que apresentam baixo custo e 
amplamente utilizados como agentes cicatrizantes pela cultura popular de diversos países (HATANAKA, 2007). O curativo úmido oleoso serve como barreira protetora contra microrganismos, evita a desidratação tecidual, mantém a temperatura corpórea e diminui os traumatismos durante a substituição dos curativos. Estudos envolvendo a função dos ácidos graxos sobre células do sistema imune mostram o importante caráter imunomodulador destas substâncias (HATANAKA, 2007). Dentre os ácidos graxos constituintes deste óleo, destaca-se o ácido linoléico que faz parte da composição complexa dos lipídeos da epiderme, contribuindo na função barreira da pele e ajudando a controlar a perda de água trans-epidérmica.

A presente investigação tem as seguintes metas: (a) identificar os ácidos graxos do óleo de Castanha do Brasil empregando as técnicas de cromatografia em fase gasosa (CG) e cromatografia em fase líquida (CLAE); (b) desenvolver uma formulação cosmética para incorporação do óleo de Castanha do Brasil; (c) realizar um estudo de estabilidade física da formulação desenvolvida; (d) avaliar a estabilidade térmica dessa formulação; (e) avaliar a estabilidade térmica do óleo de Castanha do Brasil; (f) desenvolver um método analítico utilizando a eletroforese capilar com o objetivo de separar e identificar esses ácidos na formulação cosmética. 


\section{REVISÃO DA LITERATURA}

\subsection{Estrutura da pele e de seus anexos}

A pele é o maior órgão que reveste e delimita nosso corpo, representando $15 \%$ do peso corporal (GARCIA, 1996). Existem dois tecidos interligados: a epiderme, na parte superior, e a derme, que está intimamente ligada ao tecido conjuntivo laxo e adiposo adjacente (tecido subcutâneo), constituindo a hipoderme. Esta divisão estrutural é mais de natureza anatômica, pois existe na pele uma interdependência funcional e estrutural entre estes tecidos, que serve de suporte a toda a sua complexidade (CUNHA et al., 2004).

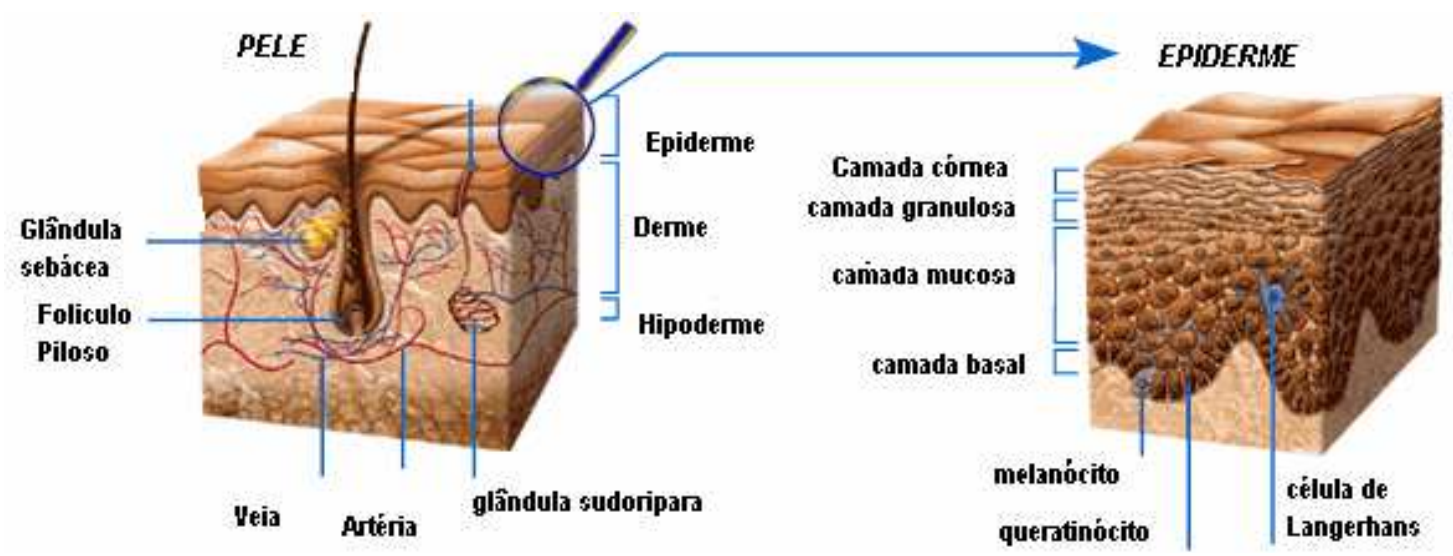

Figura 1: Camadas da pele e estrutura da epiderme. (Fonte: www.bioderma.fr/conceils/informations.asp)

A epiderme é a camada externa, sem vascularização, e pode ser formada por até cinco camadas de dentro para fora, estrato germinativo, espinhoso, granuloso, lúcido e córneo (Figura 1). Trata-se de uma emulsão do tipo água em óleo formada por fração lipossolúvel (ceramidas, colesterol, ceras, esqualeno, ácidos graxos e triglicéridos) e por uma fração hidrossolúvel (água, cloretos de sódio, potássio, cálcio, magnésio e substâncias orgânicas, tais como uréia, aminoácidos, amoníaco, vitaminas, glucose) (CUNHA et al., 2004).

As principais funções exercidas pela película hidrolipídica são:

- proteção da hipoderme, como umectante em relação a desidratações e contra excesso de umidificação (CUNHA et al., 2004); 
- estabilização do pH, devido ao poder tampão exercido, sobretudo pelos aminoácidos e sais, o que permite a presença de uma flora saprófita que defende a pele contra microorganismos patogênicos (CUNHA et al., 2004);

- lubrificação e proteção da camada formada por células mortas (camada córnea), de células anucleadas e queratinizadas com o que forma, assim, uma barreira contra as agressões externas (CUNHA et al., 2004).

A derme é considerada como componente estável da pele, ao contrário da epiderme, que está em renovação permanente, cujas células basais mantêm a capacidade embrionária de multiplicação. É a característica mais importante deste órgão e, explica a funcionalidade biológica da pele.

As duas camadas inferiores, derme e hipoderme, formam a denominada pele viva que é atravessada, em todos os sentidos, por nervos, vasos sanguíneos, glândulas sudoríparas e unidades pilossebáceas, que são constituídas por pêlos e por glândulas sebáceas.

\subsection{Composição química da pele}

O elemento mais importante da composição química da pele é a água, com um valor cerca de $70 \%$, que se distribui diferentemente nas diversas camadas da pele, sendo a hipoderme a mais hidratada.

As substâncias de natureza protéica representam 27,5\% dos constituintes químicos da pele, com aminoácidos, proteínas e outros constituintes azotados.

Os lipídeos simples (ácidos graxos, colesterol, esqualeno), os lipídeos complexos e os lipídeos de reserva (triglicéridos) são constituintes muito importantes.

Os sais minerais estão sempre presentes e destacam-se o sódio, potássio, magnésio, zinco, ferro, manganês, fósforo, enxofre e iodo (CUNHA et al., 2004).

\subsection{Aspectos fisiológicos da pele}

Várias são as funções desempenhadas pela pele, fundamentalmente protege o organismo não só contra agressões traumáticas como de alterações da temperatura ambiental, estabelece uma barreira entre o corpo e o meio ambiente, impedindo a penetração de microrganismos e constitui um invólucro que protege também das variações hídricas, permitindo, paralelamente, trocas gasosas e 
eliminação de produtos tóxicos (CUNHA et al. 2004; JUNQUEIRA et al., 1990; MINISTÉRIO DA SAÚDE, 2002). Além dessas funções, a pele contém e suporta a pressão dos tecidos e líquidos do organismo, tem propriedades plásticas muito importantes, capazes de acompanhar os movimentos normais do corpo. Este caráter elástico, ao mesmo tempo resistente, é atribuído à disposição das fibras de elastina e das fibras de colágeno, que sobre tensão, tendem a orientar-se paralelamente ao eixo da força aplicada.

Ao envelhecer, a pele torna-se mais fina e perde a elasticidade por alteração das fibras e da sua própria organização, dando-se a atrofia do panículo adiposo com aparecimento de rugas numa primeira fase. Em uma idade avançada, o próprio aspecto da face se modifica, e esta se torna achatada na zona das bochechas, por perda da camada adiposa e aparecimento na pele de uma cor macilenta (STEINER, 2001).

\subsection{O envelhecimento cutâneo}

A pele possui dois tipos de envelhecimento: o intrínseco e o extrínseco. O intrínseco é decorrente do desgaste natural do organismo, causado pelo passar dos anos: a pele aparenta mais fina, com pouca elasticidade, mais flácida e apresentando finas rugas, porém sem manchas ou alterações da sua superfície. Já o envelhecimento extrínseco é causado por agressões do meio ambiente, por exemplo, poluentes ambientais, álcool, tabaco e o sol. Nesse tipo de envelhecimento destacamos o fotoenvelhecimento que é causado pela radiação solar. Os raios ultravioletas (UVA, UVB e UVC) provocam danos estruturais à pele, alterando a pigmentação cutânea, provocando enrugamento, causando o envelhecimento precoce e também formando radicais livres reativos (EVANS, 2000). A radiação UV propicia a formação dos radicais livres produzidos e, com isso, eleva o número de lesões oxidativas não reparadas, que alteram o metabolismo e são responsáveis pelo envelhecimento precoce, elevando o risco de aparecimento de câncer cutâneo (DRAELOS, 1999; VELASCO et al. 2004).

O envelhecimento cutâneo tem adquirido grande importância nas últimas décadas, despertando muito interesse na classe científica, que procura entendê-lo melhor, transformando-o em objeto de trabalho (OLIVEIRA, 2004). 
O processo de envelhecimento é acompanhado pelo ressecamento do extrato córneo, portanto a manutenção e o fortalecimento da hidratação desta barreira são de fundamental importância no tratamento antienvelhecimento. Mantendo a pele hidratada, conserva-se sua firmeza, elasticidade e o aspecto jovial. Atualmente, temos no mercado formulações leves, com toque agradável, adequadas à aplicação diária, como emulsões estabilizadas por polímeros e com perfil lipídico equilibrado (GARCIA, 1996; LIBARDI, 1999).

A prevenção e a proteção são os objetivos principais na terapia tópica no combate ao envelhecimento. A formulação, a estabilização e os sistemas de liberação tópica de componentes ativos são fatores de fundamental importância para a Cosmetologia, visando desenvolver formulações com boa penetrabilidade e melhor atuação filmógena protetora (GARCIA, 1996).

Nesse contexto, temos que pele hidratada é aquela com quantidade adequada de água em todas as suas camadas. Nesta situação ela será saudável, macia, elástica e flexível.

A epiderme está sempre se renovando e sua última camada, que faz contato com o meio exterior é chamada de camada córnea. Isto ocorre porque as células perderam o núcleo, porém, mantiveram a estrutura com grande quantidade da proteína denominada queratina (STEINER, 2001).

A camada córnea é a principal responsável por manter a quantidade de água em todos os níveis da pele. Se ela estiver funcionando de forma inadequada, a perda de água pode ser grande, levando à desidratação cutânea (STEINER, 2001).

A epiderme também é responsável pela regeneração da pele. A cada 28 dias uma célula caminha desde a junção dermoepidérmica até o extrato córneo, desprendendo-se então como uma célula morta. Quando a pele encontra-se desidratada, esta reconstituição e troca ficam alteradas, dificultando a regeneração cutânea natural. Por isso, a hidratação é tão importante para a cútis (STEINER, 2001).

Para o bom funcionamento do mecanismo de hidratação deve haver uma capacidade controlada de reter água pelo extrato córneo, de modo que a taxa de evaporação da água permaneça sempre a mesma. Isto irá depender da composição e integridade da camada córnea assim como o nível de agressão do meio exterior.

Quando houver alterações na superfície da camada córnea (queimadura, escoriações, rompimento) ou perda excessiva de lipídeos ou de hidratantes naturais, 
a pele torna-se seca, áspera, sem elasticidade ou flexibilidade. O sol, os poluentes, a umidade relativa do ar também são fatores que interferem na hidratação da pele. Além disso, certas doenças como atopia e ictiose (doenças que mudam a camada córnea) e também fotoenvelhecimento interferem na capacidade hidratante da pele.

Os constituintes naturais do extrato córneo são formados por aminoácidos, carboxilato pirrolidone (PCANA), uréia, sais minerais, água e lactatos. As gorduras de superfície (sebo) como colesterol, ácidos graxos e ceramidas também são importantes para evitar a perda de água (STEINER, 2001).

\subsubsection{A hidratação na proteção ao envelhecimento cutâneo}

A proposta de hidratação ativa é cada vez mais sedutora, porque além da manutenção aquosa há o estímulo para sua regeneração (GARCIA, 1996).

A aplicação tópica de produtos vem crescendo mercadologicamente, e também dentro da Ciência Cosmética, visando combater vários problemas de pele, como evitar o ressecamento através do uso de hidratantes e emolientes; garantir uma fotoproteção eficaz e diminuir os processos oxidativos e/ou produtos resultantes. Porém, cosméticos hidratantes não alteram a estrutura da derme, portanto não são sempre considerados de combate ao envelhecimento, apesar de provocarem alterações indiretas nesse nível, que dependem da concentração de água do tecido e da vascularização. O estímulo à formação de fibras de sustentação e elasticidade e/ou à redução na interferência nos processos energéticos celulares se devem a substâncias ativas isoladas ou a uma associação destas composta por vitaminas, oligoelementos, aminoácidos, ácidos graxos e proteínas, entre outras (GARCIA, 1996).

A adição de compostos que alteram a permeabilidade da pele, os denominados promotores de absorção ou "enhancers", podem aumentar a difusão de substâncias de difícil penetração.

Dentre as substâncias que podem alterar a permeabilidade da pele, aumentando a difusão de substâncias de difícil penetração estão os ácidos graxos como o ácido oléico, linoléico, láurico, cáprico e outros.

Os ácidos graxos também aumentam a absorção de substâncias lipofílicas. O aumento da absorção é dependente do veículo utilizado e da estrutura do ácido 
graxo (representada pelo número de carbonos e ligações duplas que constituem a cadeia apolar). Os ácidos graxos com cadeias formadas por 10 ou 12 átomos de carbonos são os mais efetivos como "enhancers". O ácido oléico, com 18 carbonos e uma insaturação (18:1) mostrou ser o mais efetivo enquanto o ácido esteárico, com 18 carbonos e saturado (18:0) geralmente não apresenta as propriedades dos promotores. Outros ácidos graxos insaturados de cadeia longa como 0 ácido miristoléico (14:1), palmitoléico (16:1), linoléico (18:2), linolênico (18:3) também apresentam propriedades promotoras (OLIVEIRA et al., 1996).

Encontram-se no mercado formulações cosméticas com diversos compostos para a hidratação da pele, dentre eles temos:

a) Extratos vegetais e marinhos: os hidratantes atuais exploram a potencialidade protetora, filmógena e umectante de princípios ativos naturais como, figo da Índia, extratos vegetais protéicos não hidrolisados como de soja, trigo, arroz, e marinhos, como microalgas e os derivados de colágeno de peixe (GARCIA, 1996).

b) Óleos: como, amêndoas doces, uva mosquete, camélia, gérmen de trigo, em concentrações que variam de 0,5 a 5\%, geralmente contendo triglicerídeos, vários ácidos graxos (linoléico, palmítico) e lecitina. Possuem função protetora aos raios UV, bioestimulante, antioxidante, além de hidratante.

c) Fitoesteróis: extrato vegetal extraído do gérmen de trigo, da soja e da alfazema, possuem estrutura semelhante aos esteróis, encontrados na porção insaponificável de óleos e gorduras e formam um filme hidrofóbico não oclusivo sobre a pele. Muitas vezes se elabora um creme hidratante associando-se fitoesteróis, vitamina $E$ e outras substâncias da pele (GARCIA, 1996; RUBIM, 1997).

d) Vitamina E: Componente muito promissor e o mais lipofílico, protegendo os lipídeos insaturados de reações de oxidação, estando presente no plasma e membranas celulares de alguns tecidos do corpo. É fácil entender o uso repetitivo dessa vitamina, em formulações de cremes O/A (óleo-em-água), na concentração de $5 \%$, sob a forma de linoleato e acetato, pois exerce um efeito benéfico sobre a capacidade da pele de reter água, provocando uma umectação interna e reduzindo rugas e finas marcas de expressão ao redor dos olhos (IDSON, 1994; TAMBURIC et al., 1999). 


\subsection{Cosméticos}

Definição

De acordo com a Resolução RDC ${ }^{0} 211$, de 14 de julho de 2005 da Agência Nacional de Vigilância Sanitária (ANVISA); cosméticos, produtos de higiene pessoal e perfumes são preparações constituídas por substâncias naturais ou sintéticas, de uso externo nas diversas partes do corpo humano, pele, sistema capilar, unhas, lábios, órgãos genitais externos, dentes e membranas mucosas da cavidade oral, com o objetivo exclusivo ou principal de limpá-los, perfumá-los, alterar sua aparência e ou corrigir odores corporais e ou protegê-los ou mantê-los em bom estado (BRASIL, 2005).

Os componentes de um produto cosmético devem estar descritos nos compêndios técnicos da International Cosmetics Ingredients (INCl) garantindo, assim, uma maior segurança. Não devem apresentar nenhum risco à saúde humana nas condições de uso preconizadas ou razoavelmente previsíveis (RIBEIRO, 2006).

\subsubsection{Emulsões}

Dentre inúmeros veículos utilizados para formulações com ativos cosmetológicos, a emulsão faz parte de um grupo de veículos que apresentam boa aceitação por parte dos consumidores.

Uma emulsão é um sistema de dois (ou mais) ingredientes imiscíveis (normalmente, líquidos), no qual um dos ingredientes - a fase dispersa/interna - é suspensa ou dispersa através de outro ingrediente (a fase contínua/externa) na forma de gotículas separadas (KLEIN, 2005).

Considerando as fases contínuas e descontínuas de uma emulsão simples, classificamos como tipo óleo-em-água $(\mathrm{O} / \mathrm{A})$, aquela em que o óleo constitui a fase dispersa, interna ou descontínua e a água, a fase dispersante, externa ou contínua; caso ocorra a água como fase dispersa, serão obtidas emulsões do tipo $(A / O)$. As emulsões do tipo O/A são quantitativamente mais utilizadas devido ao seu aspecto menos oleoso e mais agradável para aplicação tópica (SILVA \& SOARES, 1996).

São misturas relativamente estáveis de água e componentes oleosos ou graxos, na presença de um emulsionante. As propriedades do sistema água/ óleo 
são drasticamente modificadas após a adição do emulsionante, sendo importante o entendimento dos fatores físico-químicos relacionados às atividades superficial e interfacial responsáveis pela estabilidade da emulsão. A natureza e características da emulsão são grandemente determinadas pela natureza do emulsionante ou combinação de emulsionantes utilizados pelo formulador (SANCTIS, 2004).

Geralmente, os produtos hidratantes são encontrados na forma de emulsões (cremes e loções), sendo que a fase lipídica promove a oclusão e a fase aquosa possui ingredientes higroscópicos que propiciam a umectação da epiderme. Dentre os mecanismos de ação desses produtos podemos citar:

- Oclusão: Promovido por componentes lipídicos como vaselina, óleos, lanolina, ésteres de ácidos graxos dentre outros (LIBARDI, 1999).

- Umectação: Ocorre com a aplicação de substâncias higroscópicas que retém água na superfície da pele, como sorbitol, glicerina e propilenoglicol (LIBARDI, 1999).

- Hidratação ativa: Oferecida por componentes ativos intracelulares com capacidade higroscópica ou através da ação na estrutura celular, como os alfahidroxiácidos e seus derivados, fitoesteróis, uréia, lactato de amônio, vitamina $E$ (LIBARDI, 1999).

\subsubsection{Matérias-primas utilizadas em emulsões cosméticas}

A água (veículo) é o ingrediente mais utilizado. Como nem todos os ingredientes cosméticos são miscíveis em água ocorre uma necessidade prática de estabilizar e suspender as misturas heterogêneas de água com outras matérias primas como líquidos parafínicos, óleos vegetais, ceras naturais e sintéticas e pigmentos inorgânicos através de um processo de emulsificação no qual uma das fases está dispersa na outra (SANCTIS, 2004).

Os excipientes utilizados na preparação das emulsões cosméticas são:

a) Emolientes: são substâncias oleaginosas, insolúveis em água que são aplicadas sobre a pele para promover maciez e suavidade. Atuam como uma barreira física, protegendo a pele dos irritantes hidrossolúveis, bactérias presentes em partículas de poeira e efeitos danosos do ar. Os emolientes de origem vegetal são os que apresentam menor comedogenicidade (MARTINS, 2003). Exemplos de emolientes 
são: álcool estearílico propoxilado, óleo mineral, óleos vegetais, silicones, ésteres graxos, etc (SANCTIS, 2004).

b) Emulsificantes: Quando adicionamos emulsificante a uma emulsão contendo água e óleo é formado na interface dos dois componentes um filme pelas moléculas do emulsificante orientadas de acordo com a sua polaridade. Este filme irá reduzir a tensão interfacial entre os líquidos. Desta forma os líquidos imiscíveis poderão ser dispersos um no outro, através da agitação e formação de micelas (PALMA et al, 2004). Exemplos: tensoativos não iônicos como monoestearato e monooleato de sorbitan, monoestearato e monooleato de sorbitan etoxilados, álcool estearílico etoxilado, álcool cetoestearílico (SANCTIS, 2004).

c) Umectantes: Podem desempenhar vários papéis nas emulsões. Podem se ligar à água (por uma ligação de hidrogênio) e, por isso, são considerados "hidratantes". Bons exemplos de umectantes são: glicerina, propileno glicol e hialuronato de sódio. Os umectantes podem funcionar como solubilizantes para preservantes parabenos e "ingredientes ativos". Também podem ajudar nas características de remoção das emulsões, alterando os efeitos de "espalhabilidade", uma técnica usada nas maquilagens líquidas para reduzir a formação de riscos. Os umectantes podem melhorar a estabilidade em congelamento, tanto nas emulsões $\mathrm{O} / \mathrm{A}$ como nas $\mathrm{A} / \mathrm{O}$ (KLEIN, 2005). Exemplos: polietilenoglicóis (ATPEG 400, ATPEG 600), glicerina, sorbitol, polissacarídeos, etc (SANCTIS, 2004).

d) Espessantes: conferem maior opacidade ao creme e aumentam a viscosidade da formulação (MARTINS, 2003). Exemplos: álcoois graxos, ésteres graxos, etc. (SANCTIS, 2004).

e) Conservantes: são substâncias que evitam a proliferação microbiana em produtos e conferem estabilidade ao produto, segurança ao consumidor, são efetivos contra formas vegetativas de bactérias e agem na estrutura da célula (MARTINS, 2003).

f) Antioxidantes: barram ou retardam a oxidação dos componentes das formulações tais como: fragrâncias, corantes, ativos, ceras e óleos vegetais (MARTINS, 2003). Exemplos: butilhidroxitolueno, vitamina E (SANCTIS, 2004). 
g) Sequestrantes: são substâncias que complexam íons metálicos inativando-os e impedindo sua ação danosa sobre os componentes da formulação. Eles podem estabilizar polímeros doadores de viscosidade e mantêm a transparência de sistemas que podem turvar com a presença de metais (MARTINS, 2003). Exemplos: etilenodiamino diacetato de sódio, citrato de sódio (SANCTIS, 2004).

\subsubsection{Formulações gel-creme}

As formulações gel-creme adquiriram grande força e aceitação no mercado brasileiro a partir das farmácias de manipulação, que desenvolveram formulações do tipo "oil-free", com menor quantidade possível de óleos e com aspecto de creme. De um modo geral, elas são constituídas de uma base em gel, emulsificantes, substâncias oleosas ou silicones, adquirindo um aspecto leitoso ou cremoso.

O gel é um sistema solvente-polímero, que contém uma rede tridimensional de ligações bastante estáveis, quase não afetadas por movimento térmico. Podem ser subdivididos em dois grupos, dependendo das ligações entre as cadeias da rede. Os do tipo I são sistemas irreversíveis com uma rede tridimensional formada por ligações covalentes entre as macromoléculas. Os géis do tipo II, mais comumente usados em farmácia, são reversíveis pelo calor e mantidos por ligações intermoleculares do tipo ligação hidrogênio (FLORENCE e ATWOOD, 2003).

Devido à baixa concentração de substâncias oleosas, a formulação gel-creme apresenta sensação tátil de gel, com certa refrescância, especialmente para peles oleosas e mistas, podendo ser utilizada por todos os tipos de pele, dependendo, porém, dos demais componentes agregados (MARTINI, 2005).

\subsubsection{Estabilidade de emulsões}

A estabilidade de uma emulsão relaciona-se principalmente à viscosidade da fase interna. Partículas pequenas dispersas em um líquido (ou gás), estão em constante choque devido ao movimento browniano. Diversas instabilidades podem ocorrer no sistema devido a estas movimentações e interações entre as fases: 
inversão de fases, coalescência, formação de creme ou creaming e até a quebra total da emulsão (FLORENCE e ATWOOD, 2003).

\section{6. Óleos vegetais}

\subsubsection{Generalidades}

Nas terras brasileiras existem seis biomas, e, dentre eles, a maior floresta tropical do mundo: a Floresta Amazônica. A flora brasileira apresenta biodiversidade incomparável e algumas empresas nacionais e multinacionais vem se destacando pelo desenvolvimento de insumos naturais padronizados e de produtos cosméticos (BABY, 2005).

A vegetação amazônica é rica em plantas, cujos óleos e gorduras podem ser empregados na cosmetologia, tais como aqueles extraídos do licuri, oitica, murumuru, ucuuba, pequi, cupuaçu, bagaçu, andiroba, pariparoba, copaíba (OLIVEIRA, 2004) e Castanha do Brasil.

Óleos e gorduras têm um papel fundamental na alimentação humana. Além de fornecerem calorias, agem como veículo para as vitaminas lipossolúveis, como A, $\mathrm{D}, \mathrm{E}$ e K ; são fontes de ácidos graxos essenciais como o linoléico, linolênico e araquidônico entre outros (KARLESKIND, 1996; GURR \& HARWOOD, 1996).

Os óleos vegetais são produtos naturais constituídos por uma mistura de ésteres derivados do glicerol (triacilgliceróis ou triglicérideos), cujos ácidos graxos contêm cadeias de 8 a 24 átomos de carbono com diferentes graus de insaturação. Conforme a espécie de oleaginosa, variações na composição química do óleo vegetal são expressas por variações na relação molar entre os diferentes ácidos graxos presentes na estrutura. Portanto, a análise da composição de ácidos graxos constitui o primeiro procedimento para a avaliação preliminar da qualidade do óleo bruto e/ou de seus produtos de transformação e isto pode ser obtido através de vários métodos analíticos tais como a cromatografia em fase líquida, cromatografia em fase gasosa e a espectroscopia de ressonância magnética nuclear de hidrogênio (MORETTO \& FETT, 1998). 
Os componentes mais expressivos dos óleos e gorduras são os triacilglicerídeos e suas propriedades físicas dependem da estrutura e distribuição dos ácidos graxos presentes (CASTRO et al., 2004).

\subsection{2. Óleos vegetais e aplicação cosmética}

Em emulsões cosméticas, os óleos vegetais são constituintes da fase oleosa, e destacam-se por propriedades como baixa viscosidade e peso molecular, o que os tornam menos oclusivos que os óleos minerais; boa penetração na pele e capacidade de transporte de agentes terapêuticos, compatibilidade com a pele e possibilidade de fornecer nutrientes como tocoferóis, carotenóides e ácidos graxos essenciais (SILVA, 1997). Dissolvem numerosas substâncias insolúveis na água, como, por exemplo, essências, compostos fenólicos, terpenos, ácidos aromáticos entre outras. Extraídos das folhas, sementes, caroços, plantas leguminosas, ricas em nutrientes podem ser incorporados a outros ativos emolientes, fragrâncias, corantes, veículos para a aplicação de fármacos à pele e como componentes básicos de cosméticos decorativos. A razão para justificar o uso de ceras e gorduras derivadas de animais ou plantas em cosméticos é acreditar que são semelhantes ou mesmo idênticos àqueles encontrados na pele humana (GONÇALVES, 2000). Colaboram ainda, no momento, para o desenvolvimento dos estudos sobre aplicação dos óleos vegetais, a elevação do preço dos produtos petroquímicos e a tendência ao consumo de produtos naturais (SILVA, 1997).

Desta forma, os óleos vegetais vêm sendo usados como veículos adequados para incorporação de várias substâncias ativas ou insumos benéficos à pele, e como matéria-prima emoliente em emulsões cosméticas.

Os emolientes têm a função de preencher os espaços entre as camadas da pele descamativa com gotículas de óleo. O termo "emoliente" muitas vezes presente nas descrições de funções de produtos cosméticos deriva do latim "emoliere" que significa abrandar, caracterizado por sua suavidade e flexibilidade provocada por conteúdos hídrico adequados, facilitados pelo produto que dificulta a perda excessiva de água. O óleo por si só, constitui-se como matéria-prima fundamental nas formulações cosméticas como substância emoliente ou então como base na preparação de muitos derivados, álcoois, ésteres e outros. O óleo vegetal, quando aplicado na pele, devido a sua tensão superficial e imiscibilidade com água não 
forma película contínua, dispondo-se em gotículas nos espaços interfoliculares e entre os poros sudoríparos Conseqüentemente, a perspiração não é impedida e a pele também não se torna seca, porque o óleo incorporado na camada córnea impede a descamação tornando-a mais macia (MITLAG et al., 1992).

Pereira (2008) realizou um estudo de estabilidade acelerado em emulsões não iônicas contendo vários óleos vegetais, dentre deles o óleo de Castanha do Brasil e observou que as emulsões que tendiam a ser menos estáveis foram exatamente aquelas que possuíam valores mais baixos da relação graxa linoleica/oléica. Este comportamento sugere que a concentração de ácido linoleico no óleo que compõe a referida emulsão pode estar influenciando na fase oleosa da emulsão. Nos casos de estabilidade ao envelhecimento acelerado tal influência sempre está relacionada à boa formação dos glóbulos dispersos, que uma vez pequenos constituindo inúmeras micelas não se unirão fácil para coalescer. Pereira relatou em seu estudo que óleos vegetais com alto teor de ácidos graxos insaturados, especialmente o ácido linoléico, quando incorporado a emulsões não iônicas e aniônicas promove elevado grau de emoliência e espalhabilidade, além de características reológicas desejáveis à estabilidade e processamento industrial.

Uma vez que a velocidade de auto-oxidação depende do número de duplas ligações presentes na molécula, seria de esperar que os óleos vegetais exibissem maior susceptibilidade à deterioração que as gorduras animais. Porém, tendem a oxidar mais lentamente do que seria de esperar a partir da sua composição química, porque contem quantidades significativas de tocoferóis, os quais atuam como antioxidantes naturais (SIMS \& FIORITI, 1980).

É importante destacar que na área da Fitoterapia existe a necessidade de se realizar estudos adequados para o desenvolvimento de matéria-prima fitoterápica e dos produtos que incorporem insumos naturais. A determinação dos teores de substâncias ativas, a realização de testes microbiológicos, a avaliação de segurança e eficácia, e os estudos da estabilidade garantem o consumo de produtos confiáveis. Para tanto, a busca de conhecimento nas instituições de pesquisa favorece 0 desenvolvimento nas áreas da Cosmética e da Dermatologia (BABY, 2005).

Dentro deste contexto, o uso de extratos naturais padronizados e de atividades farmacológica/cosmética comprovadas está sendo amplamente estudado para a sua utilização em produtos cosméticos, acompanhando a tendência mundial 
de sua valorização em associação ao marketing que direciona o uso destes produtos com um posicionamento ecologicamente correto (BABY, 2005).

$O$ aumento da população do mundo em desenvolvimento e o crescente interesse das nações industrializadas têm ampliado enormemente a demanda por ativos de origem vegetal e os produtos derivados dela (BABY, 2005).

\subsubsection{Castanha do Brasil}

Aspectos botânicos

A Castanha do Brasil (Bertholletia excelsa) (Figura 2) é uma espécie da família de Lecythidaceae, gênero Bertholletia, nativa do sudeste da Amazônia, distribuindo-se na bacia amazônica nos países Bolívia, Brasil, Colômbia, Peru e Suriname. No Brasil, inclui os estados de Rondônia, Acre, Amazonas, Pará e norte dos estados de Goiás e Mato Grosso (LORENZZI, 1992; GENTRY, 1996).

A árvore amazônica da Castanha do Brasil é de grande porte, podendo atingir entre 30 e 50 metros de altura (FERREIRA, 2005) com idade estimada entre 800 e 1200 anos. O fruto da castanha se chama ouriço, pesa cerca de um quilo e pode conter de 15 a 24 sementes (CUNHA, 2004). Suas sementes são usadas na elaboração de produtos pós-barba, repositores faciais, produtos antiidade e previne o aparecimento de estrias (FERREIRA, 2005).

Também é conhecida como castanha-do-pará e castanha-da-amazônia. Trata-se de uma árvore "intimamente ligada à cultura das populações tradicionais da Amazônia". 


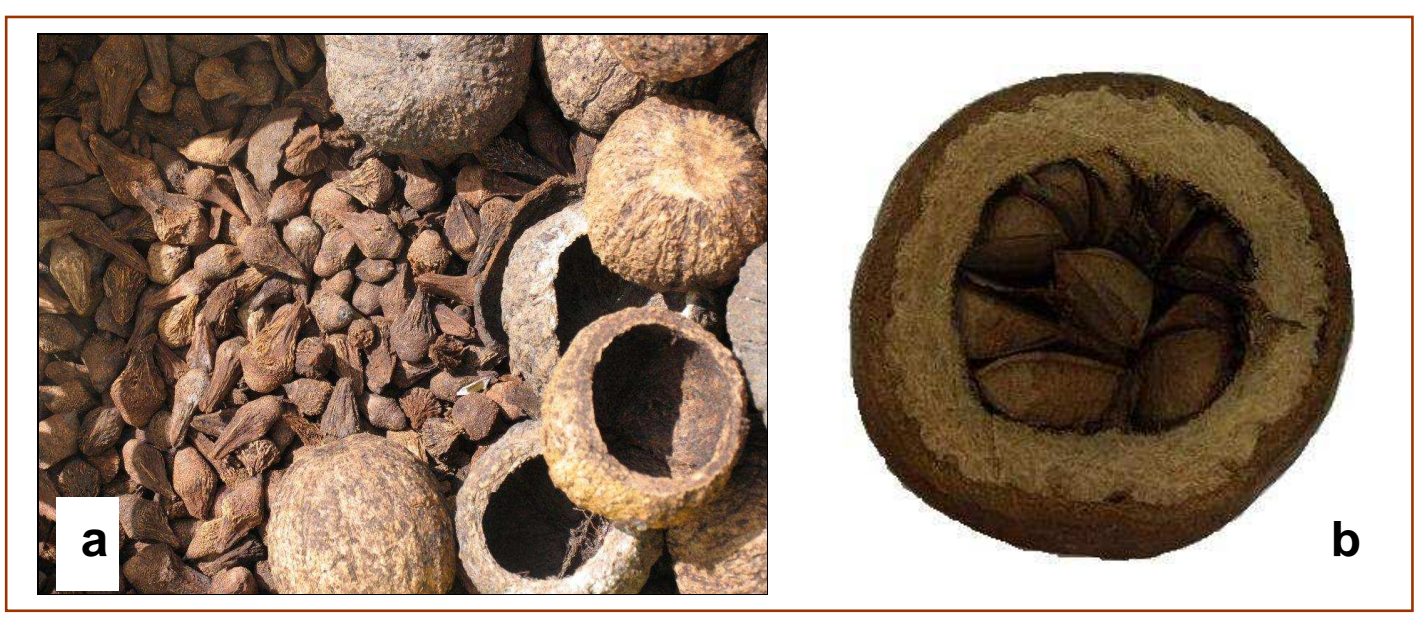

Figura 2: (a) Ouriço da castanha do Brasil sem as sementes (www.brazilianbeauty.org.br) (b) Corte transversal do ouriço da Castanha do Brasil com as sementes (foto tirada em out/2007)

É muito rica em gorduras e proteínas: verdadeira "carne vegetal", apresentando aproximadamente 17\% referente à fração peptídica e $69 \%$ à fração lipídica.

A aplicação mais importante e tradicional da Castanha do Brasil in natura é na fabricação de aperitivos na indústria alimentícia. O óleo começou a ser comercializado mais recentemente nas indústrias de suplemento alimentar, de higiene pessoal e cosméticos.

Segundo Carvalho, Ferreira e Homma (1994), após a decadência da borracha, a Castanha do Brasil passou a constituir o principal produto extrativo para exportação da Região Norte do Brasil, na categoria de produtos básicos.

A produção da castanha é totalmente extrativista e ocorre no período de chuvas, no inverno amazonense, que vai de dezembro a junho, com possíveis variações (CUNHA et al, 1997).

\subsubsection{1. Óleo de Castanha do Brasil}

O óleo da Castanha do Brasil é comestível e de altíssima qualidade, também muito utilizado como matéria-prima na fabricação de produtos farmacêuticos e cosméticos, como sabonetes finos, loções cremosas, óleos de banho, óleos para massagem, cremes para amaciar o cabelo, condicionador, produtos para barbear e pós-barba. O óleo age no tecido cutâneo, formando uma camada para impedir a evaporação da água na pele. Os ácidos insaturados são essencialmente nutritivos, 
têm grande participação fisiológica e bioquímica no processo de formação epitelial, com excelentes resultados na pele e nos cabelos. Estimula a síntese das proteínas no organismo.

O óleo de Castanha do Brasil possui em sua composição vitaminas lipossolúveis como a vitamina $A$ e a vitamina $E$ ( $\alpha$-tocoferol), que são indispensáveis na proteção da pele, pois evitam o envelhecimento e o aparecimento de rugas e flacidez. $\mathrm{O} \alpha$-tocoferol é potencialmente uma das vitaminas mais interessantes na luta contra o envelhecimento cutâneo sendo muito promissor e o mais lipofílico, protegendo os lipídeos insaturados de reações de oxidação, estando presente no plasma e membranas celulares de alguns tecidos do corpo (CAMPOS, 2007).

Contêm em sua fração insaponificável os fitoesteróis ( 1\%) que atuam a nível celular, regulando o equilíbrio hídrico e a atividade dos lipídeos da camada superficial da pele. Os fitoesteróis têm sido utilizados topicamente no tratamento de dermatites e ulcerações para estimular o processo de cicatrização. Além das vitaminas, diversos minerais e oligoelementos ( $\mathrm{Se}, \mathrm{Ca}$, Fem $\mathrm{Zn}, \mathrm{Na}, \mathrm{K}$ ) que são essenciais para a vitalidade da pele e do cabelo, estão presentes na Castanha do Brasil e em quantidades apreciáveis no óleo (CRODA, 2006).

As características físico-químicas do óleo de Castanha do Brasil estão descritas na Tabela 1.

Segundo Gomes, a fração insaponificável (1,1\%) apresenta altas concentrações de $\beta+\gamma$-tocoferol (177,72 ppm) e $\alpha$-tocoferol (74,88 ppm), compostos importantes para sua atividade antioxidante (Tabela 2) (Gomes et al. 1997).

Tabela 1: Características físico-químicas do óleo de Castanha do Brasil.

\begin{tabular}{l|c|c|}
\hline Índices & Unidades & Valores de Referência \\
\hline Peso Específico $\left(25^{\circ} \mathrm{C}\right)$ & $\mathrm{g} / \mathrm{c} \mathrm{m}^{3}$ & $0,910-0,912$ \\
\hline Índice de Refração $\left(25^{\circ} \mathrm{C}\right)$ & - & $1,464-1,468$ \\
\hline Índice de lodo & $\mathrm{G} \mathrm{I} / 100 \mathrm{~g}$ & $97-106$ \\
\hline Índice de Saponificação & $\mathrm{Mg} \mathrm{KOH} / \mathrm{g}$ & $192-202$ \\
\hline Matéria Insaponificável & $\%$ & $<1 \%$ \\
\hline \\
$\begin{array}{l}\text { VR: Physical and Chemical Characteristics of Oils, Fats, and Waxes - AOCS. } \\
\text { (www.oleodecastanhadobrasil.com.br) }\end{array}$
\end{tabular}




\subsubsection{Extração do óleo de Castanha do Brasil}

Em geral, os métodos de obtenção de óleo seguem princípios muito simples, podendo ser extraído das sementes utilizando uma prensa ou utilizando um solvente. O objetivo principal em utilizar qualquer destes métodos é o de obter, a máxima quantidade possível de óleo inalterado e livre de impurezas (STAUFFER, 1996).

A extração de óleo fixo (ou gorduras/ceras) de fonte natural sólida é mais convenientemente executada em um extrator Soxhlet. O sólido (devidamente moído) é colocado em um cartucho poroso na câmara do extrator e o solvente de extração adicionado ao balão. O solvente vaporizado e condensado na câmara do extrator dissolve o óleo (ou gordura) da amostra. Ao atingir o nível do sifão, a solução retornará ao balão e o processo repetido um número de vezes (extração contínua).

Em escala laboratorial já existem outros procedimentos possíveis para extrair o óleo de Castanha do Brasil, como a utilização do etanol e do $\mathrm{CO}_{2}$ em estado crítico (CAMPOS, 2007). 
Tabela 2: Composição da fração insaponificável do óleo de Castanha do Brasil segundo Gomes et al. (1997).

\begin{tabular}{|c|c|}
\hline Esteróis & $\%$ (relativa) \\
\hline Colesterol & 0,28 \\
\hline Campesterol & 1,74 \\
\hline Campestano & 0,21 \\
\hline Estigmasterol & 8,39 \\
\hline$\Delta$-campesterol & 0,21 \\
\hline Clerosterol & 1,53 \\
\hline$\beta-$ Sistoterol & 74,33 \\
\hline Sitosterol & 6,07 \\
\hline$\Delta$-avenasterol & 1,06 \\
\hline$\Delta$, 24-estigmastadienolo & 0,3 \\
\hline$\Delta$-estigmasterol & 4,51 \\
\hline$\Delta$-avenasterol & 1,37 \\
\hline Álcoois triterpénicos & $\%$ (relativa) \\
\hline$\beta$-amirina & 21,61 \\
\hline$\alpha$-amirina & 64,41 \\
\hline Cicloartenol & 7,41 \\
\hline 24-metilenocicloartenol & 4,62 \\
\hline Citrosradienol & 1,25 \\
\hline Tocoferóis & (ppm) \\
\hline$\delta$-tocoferol & 32,65 \\
\hline$\beta+\gamma$-tocoferol & 177,42 \\
\hline$\alpha$-tocoferol & 74,88 \\
\hline Material Insaponificável & $\%$ (relativa) \\
\hline Total no óleo de Castanha do Brasil & 1,10 \\
\hline
\end{tabular}




\section{7. Ácidos graxos}

\subsubsection{Definição}

Ácidos graxos são ácidos carboxílicos, geralmente monocarboxílicos, que podem ser representados pela forma $\mathrm{RCO}_{2} \mathrm{H}$. Na maioria das vezes, o grupamento $\mathrm{R}$ é uma cadeia carbônica longa, não ramificada, com número par de átomos de carbono, podendo ser saturada ou conter uma ou mais insaturações. O grupo carboxila constitui a região polar e a cadeia $R$, a região apolar da molécula (CURI, 2002). A cadeia de carbonos pode variar de 4 a 26 átomos (ROCHE, 1999).

A cadeia hidrocarbonada de um ácido graxo saturado existe, geralmente, sob uma forma estendida, uma vez que esta conformação linear, flexível, é o estado de menor energia. Em contraste, os ácidos graxos insaturados contém dobramentos rígidos em suas cadeias carbônicas, pois as duplas ligações não giram e uma angulação de 30 graus é produzida para cada uma das duplas ligações presentes (configuração cis). A conformação linear dos ácidos graxos saturados permite um melhor empacotamento dos mesmos, fazendo com que as moléculas fiquem mais próximas umas das outras e, com isso, aumentando a interação entre elas. No caso de ácidos graxos insaturados, a dupla ligação não permite um empacotamento tão eficiente das moléculas, fazendo com que as interações entre elas sejam menores. Como conseqüência, os ácidos graxos saturados possuem um ponto de fusão maior que os ácidos graxos insaturados (CURI, 2002).

A tabela 3 mostra a nomenclatura comum de alguns ácidos graxos.

Tabela 3: Ponto de fusão de alguns isômeros de ácidos graxos segundo Gunstone \& Norris, 1983.

\begin{tabular}{|llcc|}
\hline Nome Comum & Nome Sistemático & $\begin{array}{l}\text { Posição das } \\
\text { duplas ligações }\end{array}$ & $\begin{array}{l}\text { Ponto de Fusão } \\
(\mathrm{C})\end{array}$ \\
\hline Láurico (C12:0) & Dodecanóico & 0 & 44,2 \\
Palmítico (C16:0) & Hexadecanóico & 0 & 62,7 \\
Palmitoleico (C18:0) & Hexadecenóico & 0 & 69,6 \\
Esteárico (C18:0) & Octadecanóico & $9 \mathrm{c}-18: 1$ & 13,2 \\
Oléico (C18:1) & Octadecenóico & 9t-18:1 & 44,0 \\
Linoléico (C18:2) & Octadecadienóico & 9c, 12c-18:2 & 5,0 \\
Linolênico (C18:3) & Octadecatrienóico & 9c, 12t-18:3 & 28,5 \\
\hline
\end{tabular}




\subsubsection{Estrutura dos ácidos graxos}

As propriedades físicas dos ácidos graxos e dos compostos que os contém são largamente determinados pelo comprimento e pelo grau de insaturação da cadeia carbônica dos mesmos. A cadeia carbônica não polar é responsável pela insolubilidade dos ácidos graxos em água, embora o número de insaturações na cadeia possa favorecer o coeficiente de partição hidrofílico (CASTILHO, 1986).

Os ácidos graxos de importância comercial compreendem entre 4 a 24 carbonos, incluindo a série dos ômegas (MORETTO, 1989). Os bioquímicos propuseram uma modificação do sistema de nomenclatura para os ácidos graxos devido ao fato de que, durante a metabolização deste ao nível celular, ocorrem quebras das moléculas em unidades de carbono, iniciando pelo carbono mais distante do grupo carboxílico. Foi possível agrupar os diferentes ácidos graxos em famílias ou séries de ácidos graxos de acordo com a posição em que estes apresentam a primeira dupla ligação em suas estruturas. Além disso, vale a pena lembrar que a grande maioria dos ácidos graxos apresenta duplas ligações separadas por um carbono com ligação simples, chamado carbono metilênico.

Os ácidos graxos de ocorrência natural em óleos vegetais podem ser totalmente saturados (SAFA, do inglês, satured fatty acid), monoinsaturados (MUFA, do inglês, monoinsaturated fatty acid), ou poliinsaturados conhecidos também por PUFA (do inglês, polyunsaturated fatty acid), e que possuem no mínimo duas duplas ligações.

A presença de insaturações restringe a rotação da cadeia hidrocarbonada, fazendo com que ocorra isometria em torno da dupla ligação, que é denominada configuração cis ou trans (CURI, 2002).

Os PUFA são precursores primários de mediadores lipídicos importantes durante o processo inflamatório, como ácido araquidônico, prostaglandinas, tromboxanos e leucotrienos (Grimble \& Tappia, 1998; O.Shea et al., 2004; Calder, 2003).

À temperatura ambiente $\left(25^{\circ} \mathrm{C}\right)$, os ácidos graxos sat urados que contêm de 12 a 24 átomos de carbonos têm consistência cerosa, enquanto os ácidos graxos insaturados do mesmo comprimento de cadeia carbônica são líquidos oleosos, como os óleos vegetais, que são compostos em grande parte por ácidos graxos insaturados de cadeia longa. 
Os ácidos graxos podem ser encontrados na forma isolada, ou freqüentemente incorporados quimicamente a uma molécula de glicerol, funcionalizado como um éster constituindo, portanto, mono, di ou triglicerídeos também conhecidos por triacilgliceróis. Dentre os ácidos graxos que predominantemente compõem os óleos vegetais (CASTILHO, 1986) sejam na forma livre ou constituindo o grupo $R$ do triglicerídeo estão os seguintes: ácido palmitoleico (2); ácido oleico (3); ácido linoleico (4); ácido linolênico (5); ácido esteárico (6); ácido palmítico (7). A posição da insaturação na nomenclatura química é determinada em relação ao grupamento carboxila, e a configuração assumida é a cis. (CASTILHO, 1986).
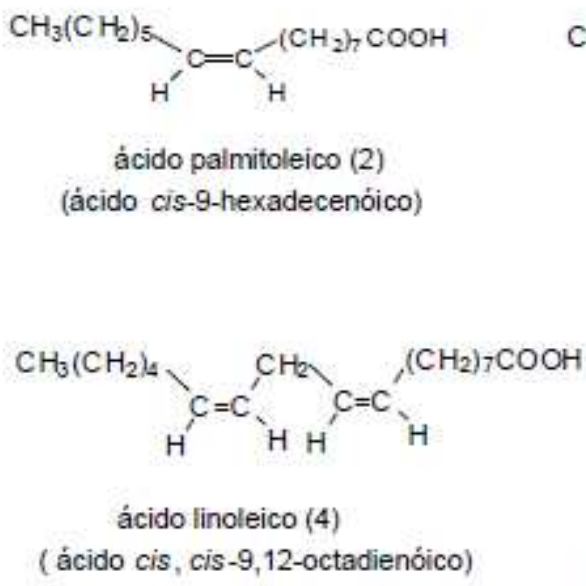

$\mathrm{CH}_{2}\left(\mathrm{CH}_{2}\right)_{16} \mathrm{COOH}$

ácido esteárico $(6)$ (ácido octade canóico)

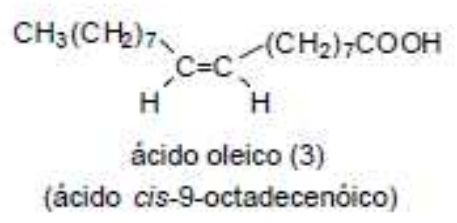

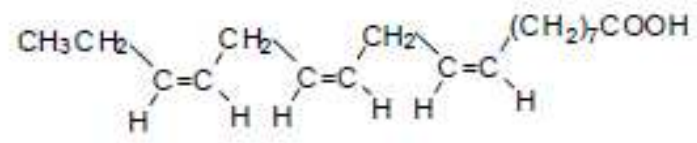

ácido linolênico (5)

(ácido cis, cis-9,12,15-octadecatrienóico)

\section{$\mathrm{CH}_{3}\left(\mathrm{CH}_{2}\right)_{14} \mathrm{COOH}$}

ácido palmítico (7)

(ácido hexadecanóico)

\subsection{3. Ácidos graxos presentes no óleo de Castanha do Brasil}

Os ácidos graxos mais abundantes no óleo de Castanha do Brasil são em ordem crescente de concentração: Ácido esteárico, palmítico, oléico, linoléico e outros ácidos presentes em pequenas proporções, como por exemplo, o linolênico e 0 araquidônico. Neste trabalho, optou-se por estudar apenas os quatro mais abundantes, uma vez que compõem a maior proporção no óleo de Castanha do Brasil.

Ácido esteárico (18:0): é o segundo mais abundante dos ácidos graxos saturados na natureza, e é encontrado nos lipídeos da maioria dos organismos vivos. Ocorre 
em alguns dos lipídios de importância comercial, em concentrações mais elevadas em ruminantes gorduras (sebo e gordura do leite) ou em óleos vegetais, como a manteiga de cacau, e na gordura hidrogenada industrialmente (The Lipid Library, 2009).

Ácido palmítico (16:0): o mais abundante dos ácidos graxos saturados na natureza, é encontrado em quantidades apreciáveis no lipídios de animais, plantas e organismos inferiores. É composto por 20 a 30\% dos lipídeos na maioria dos tecidos animais, e está presente em quantidades que variam de 10 a $40 \%$ nos óleos de sementes. Dentre as fontes comerciais, é mais abundante no óleo de palma (40\% ou mais) (The Lipid Library, 2009).

Ácido oléico (C18:1): é, de longe, o mais abundante dos ácidos graxos presentes no tecido vegetal e animal, tanto em lipídios estruturais ou em depósito de gorduras. Por exemplo, pode incluir 30 a $40 \%$ do total de ácidos graxos no tecido adiposo de animais, e de 20 a $80 \%$ dos óleos de sementes do comércio. Azeite contém até $78 \%$ de ácido oléico, e acredita-se ter especialmente valiosas propriedades nutricionais como parte da dieta mediterrânica. É o precursor biossintético de uma família de ácidos graxos com o terminal ( $n-9)$ e cadeia de 20 a 24 carbonos ou mais (The Lipid Library, 2009). O ácido oléico (Ômega-9) apresenta relevante potencial terapêutico na cura de ferimentos e na regeneração de peles lesadas (CARDOSO et al. 2004).

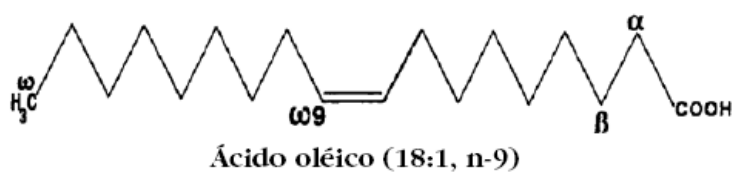

Figura 3: Estrutura do ácido oléico (w9) (ROSE et al., 1999).

Ácido linoléico (C18:2): é um elemento onipresente de lipídeos das plantas e de todos os óleos de sementes de importância comercial. Por exemplo, óleos de milho, girassol e soja, normalmente contêm mais de 50\% de linoleato, e óleo de cártamo contém até $75 \%$. Embora todo o linoleato de tecidos animais devem ser adquiridos a partir da dieta, é geralmente o mais abundante dos ácidos graxos nos mamíferos (e na maioria das classes de lipídeos) tipicamente em níveis de 15 a 25\%, embora possa elevar-se a $75 \%$ do total de ácidos graxos do coração cardiolipina. É também 
um componente significativo em óleo de peixe, embora os ácidos graxos da família do (n-3) tender a predominar neste caso (The Lipid Library, 2009). Este ácido é também conhecido como ômega-6. O ácido linoléico (Ômega-6) restaura a função barreira cutânea, reduzindo a perda de água transepidermal (TEWL), resultando no aumento da hidratação e da saúde da pele (PAEPE et al 2002). Em formulações cosméticas no combate ao envelhecimento cutâneo é empregado com sucesso em concentrações entre $2 \%$ e $3 \%$, sendo bem absorvido topicamente, provocando redução das rugas, prevenindo o ressecamento da pele, estimulando a síntese de elastina e mucopolissacarídeos na derme, normalizam a quantidade de lipídeos na epiderme e promovem a regeneração celular.

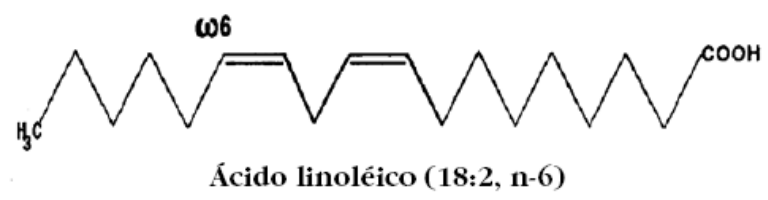

Figura 4: Estrutura do ácido linoléico (w6) (ROSE et al., 1999).

Um estudo publicado no periódico Journal of Lipid Research teve como objetivo avaliar os efeitos fotoprotetor e anti-aging da fração EPA (ácido eicosapentaenóico) do ácido linolênico (Ômega-3). O autor observou: o aumento da expressão do TGF-beta (fator de crescimento de transformação beta), resultando no aumento das fibras colágenas e elásticas, a inibição da expressão das MMP-1 e 9 UV-induzida (metaloproteinase de matriz tipos 1 e 9) em fibroblastos dérmicos humanos, sendo estas enzimas responsáveis pelo fotoenvelhecimento e a inibição da expressão da COX-2, resultando em um efeito antiinflamatório (KIM et al, 2006).

Os ácidos araquidônico e oléico exercem função importante na indução da expressão de diversos genes em linfócitos $B$, como aqueles envolvidos na defesa e reparo, fatores de transcrição, proteínas quinases envolvidas na sinalização celular e síntese de DNA (VERLENGIA et al., 2003).

Em estudo realizado por Cardoso et al. (2004), foi avaliada a influência da administração tópica dos ácidos linolênico, linoléico e oléico no processo de cicatrização de feridas em ratos. Os autores observaram que animais tratados topicamente com ácidos oléico e linoléico apresentaram redução significativa da área do ferimento a partir do $5^{\circ}$ dia de tratamento e inibição da produção de óxido nítrico local, nas primeiras 48 horas pós-cirúrgica. Neste estudo foi sugerido um 
potencial terapêutico importante dos ácidos linoléico e oléico no processo de cicatrização.

Hatanaka et al (2006) demonstraram que os ácidos oléico e linoléico podem ser utilizados em feridas como agentes pró-inflamatórios durante a fase inflamatória do processo de cicatrização, contribuindo para acelerar o processo de reparo. E o efeito pró-inflamatório destes ácidos graxos é acompanhado de sua rápida absorção e metabolização no tecido.

Em relação à utilização tópica de ácidos graxos, estes são empregados com êxito no tratamento de lesões abertas, com ou sem infecção, na espécie humana, principalmente em países da América Latina. Embora não haja estudo demonstrando claramente os efeitos celulares e sistêmicos, acredita-se que os ácidos graxos são aceleradores do processo cicatricial, atuando como agentes quimiotáticos para leucócitos, promovendo angiogênese, além de hidratação da ferida (DECLAIR, 1994; CANDIDO, 2001).

\subsubsection{Reação de hidrólise de ésteres promovida por base}

Os ésteres não apenas sofrem hidrólise ácida, mas também promovida por base. A hidrólise promovida por base é algumas vezes conhecida como reação de saponificação, à temperatura de $75-80^{\circ} \mathrm{C}$ em banho de aquecimento. $O$ refluxo de um éster em hidróxido de sódio aquoso, produzindo um álcool e o sal sódio do ácido:

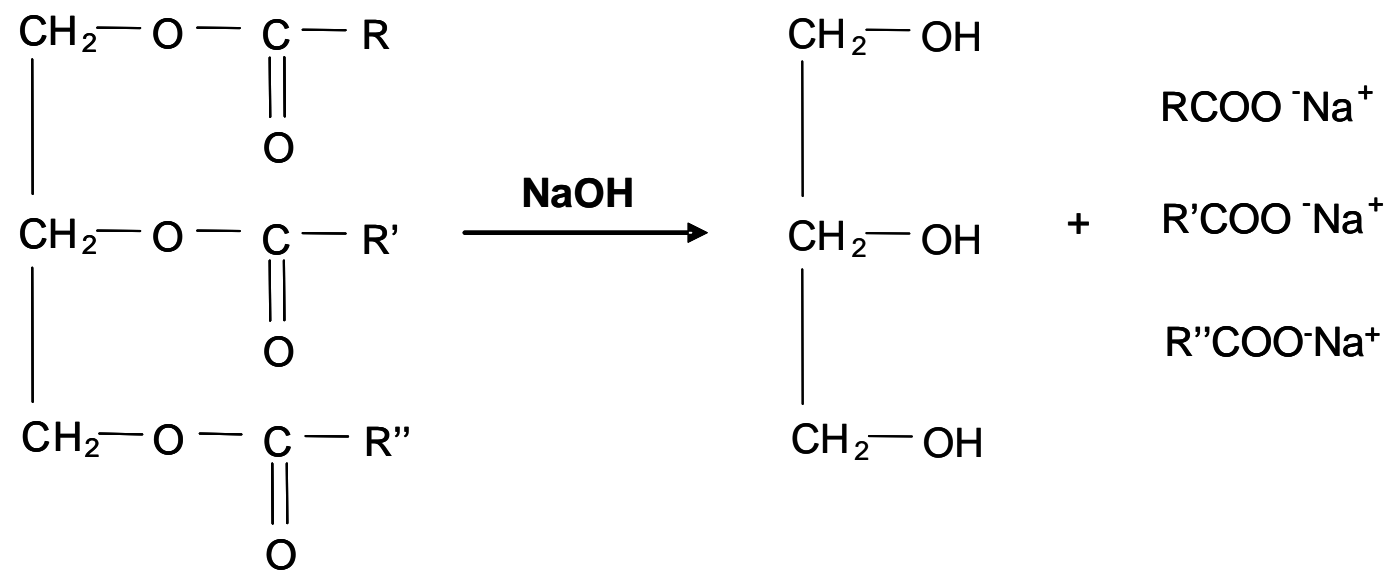

Figura 5: Esquema da reação de hidrólise dos glicerídeos (Fonte: Morrison \& Boyd) 
2.7.5. Técnicas empregadas na caracterização dos ácidos graxos

\subsubsection{Análise Térmica}

A análise térmica é definida como "grupo de técnicas por meio das quais uma propriedade física de uma substância e/ou de seus produtos de reação é medida em função da temperatura, enquanto essa substância é submetida a um programa controlado de temperatura (e sob uma atmosfera especifica). Para que uma técnica térmica seja considerada termoanalítica é necessário, segundo a definição, envolver a medição de uma propriedade física, expressa direta ou indiretamente em função da temperatura, e executada sob um programa controlado desta variável (SILVA et al, 2007).

A calorimetria exploratória diferencial (DSC) e a termogravimetria (TG) são as técnicas termoanalíticas mais difundidas e empregadas no desenvolvimento de diferentes estudos sendo aplicadas a uma grande variedade de materiais farmacêuticos (SILVA et al, 2007).

A TG fornece informações com relação às variações de massa em função do tempo e/ou temperatura sob determinadas condições atmosféricas. As análises são executadas por meio de uma termobalança (Figura 5) de elevada sensibilidade, reprodutividade e resposta rápida às variações de massa. Os parâmetros experimentais incluem: razão de aquecimento, atmosfera ( $\mathrm{N}_{2}$, ar ou outros), vazão de gás, quantidade de amostra, forma cristalina, composição do cadinho e calor de reação envolvido. As curvas obtidas fornecem informações relativas à composição e estabilidade térmica da amostra, dos produtos intermediários e do resíduo formado. A DTG é a derivada primeira da curva $T G$, os "degraus" correspondem às variações de massa, visualmente, mais accessíveis e com melhor resolução (RODRIGUES et al, 2005; VELASQUEZ et al, 2004).

A DSC é a técnica de análise térmica, na qual se mede a diferença de energia fornecida à substância e a um material de referência (termicamente estável), em função da temperatura, enquanto a substância e o material de referência são submetidos a uma programação controlada de temperatura. Existem duas configurações possíveis para aparelhos de DSC, ou seja, DSC com compensação de potência e DSC com fluxo de calor. Na primeira configuração a amostra e o material de referência são aquecidos em compartimentos separados em condições 
isotérmicas e submetidos à igual variação de potência de entrada no forno. Neste caso, os eventos são apresentados na curva DSC como picos, os ascendentes correspondem a processos endotérmicos e os descendentes a exotérmicos. No caso da DSC com fluxo de calor, a amostra e o material de referência são colocados em cápsulas idênticas, localizadas sobre o disco termoelétrico e aquecidas por uma única fonte de calor. As curvas DSC obtidas nesse sistema mostram picos ascendentes que caracterizam eventos exotérmicos, enquanto os descendentes eventos endotérmicos (WENDLANDT, 1986; MACHADO \& MATOS, 2004).

Durante um processo de aquecimento ou resfriamento, uma amostra pode sofrer alterações de temperatura devido a eventos endotérmicos ou exotérmicos. Nesse caso, registra-se o fluxo de calor diferencial necessário para manter a amostra e o material de referência à mesma temperatura. Essa diferença de temperatura entre a amostra e o material de referência é devida a fenômenos químicos (decomposição, combustão) ou físicos [mudança de estado (fusão, sublimação) e transições cristalinas] e corresponde às transições de primeira ordem, caracterizada pela formação de picos nas curvas DTA/DSC. É importante a associação de dados provenientes dos ensaios de TG/DTG e DSC, para melhor caracterização de materiais, visto que a TG/DTG indica eventos térmicos relacionados a variações de massa, enquanto a DSC detecta eventos associados ou não à perda de massa.

A análise térmica pode ser empregada para diferentes aplicações, como: identificação e análise da pureza de materiais; determinação de temperaturas e entalpias características de mudanças de estados físicos (fusão e vaporização); transformações de fases e reações e avaliação da cinética de decomposição térmica. A análise térmica não é apenas um método qualitativo, pois proporciona resultados quantitativos termodinâmicos e cinéticos quanto às propriedades dos materiais, podendo inclusive ser empregada para caracterizar material de síntese, com a vantagem do menor tempo de ensaio e a utilização de pequenas quantidades de amostras (CAMMENGA, EPPLE, 1995).

Alguns autores têm contribuído com trabalhos em que aplicam a análise térmica em estudos de matérias-primas de uso cosmético e à aplicação das várias técnicas termoanalíticas no desenvolvimento, produção e controle de produtos cosméticos. Inclusive, é possível caracterizar estruturas do fio de cabelo com 
objetivo de verificar o dano de tratamentos capilares e a eficácia de substâncias cosméticas aplicadas.

Os óleos fixos e essenciais, gorduras, ceras e ácidos graxos livres são matérias-primas amplamente utilizadas na área cosmética em função de suas características de emoliência e hidratação da pele; fabricação de perfumes ou mesmo como fonte para síntese de outros produtos. Diversos trabalhos citaram a análise térmica como método de caracterização, de avaliação do comportamento térmico e da estabilidade, podendo ser empregada no controle de qualidade de matérias-primas e produtos.

Permal e colaboradores avaliaram a variação das propriedades físicas de amostras de cremes, sendo verificadas variações do perfil das curvas TG e na reologia, entre amostras analisadas, provenientes de diferentes fabricantes, apesar do conteúdo similar de água (Permal et al.,1997).

Fujimori e colaboradores utilizaram a análise térmica na determinação quantitativa da água fixa interlamelar e da água dispersa em creme O/A, importante para definir as propriedades desta forma cosmética (Fujimori et al.,1993).

Com relação à estabilidade das emulsões, Silva e colaboradores propuseram a aplicação da análise térmica na avaliação de emulsões O/A, sendo abordada a liberação de água a partir da elaboração de curvas TG, uma vez que a temperatura de liberação da água é uma primeira característica representativa da força de ligação da água. Foi sugerida a técnica para o desenvolvimento de formas de liberação controlada de água e a investigação de transição de fase e estabilidade de formulações (Silva et al., 1994).

\section{Estudo Cinético de Decomposição}

A literatura relata inúmeros estudos cinéticos baseados em termogravimetria (TG) com o intuito de elucidar mecanismos de reação no estado sólido, tais como: decomposição térmica, oxidação, redução, cristalização e outros (HUANG et al, 2001).

Um dos métodos empregados no estudo cinético de fármacos é o que utiliza um platô de aquecimento constante, próximo da temperatura de decomposição da amostra, dito método isotérmico. No método isotérmico o cálculo da energia 
de ativação é baseado na equação de Arrhenius: $k(T)=A \times e$, onde $A$ representa 0 fator freqüência, $E$ a energia de ativação, $R$ a constante geral dos gases e $T$ a temperatura absoluta.

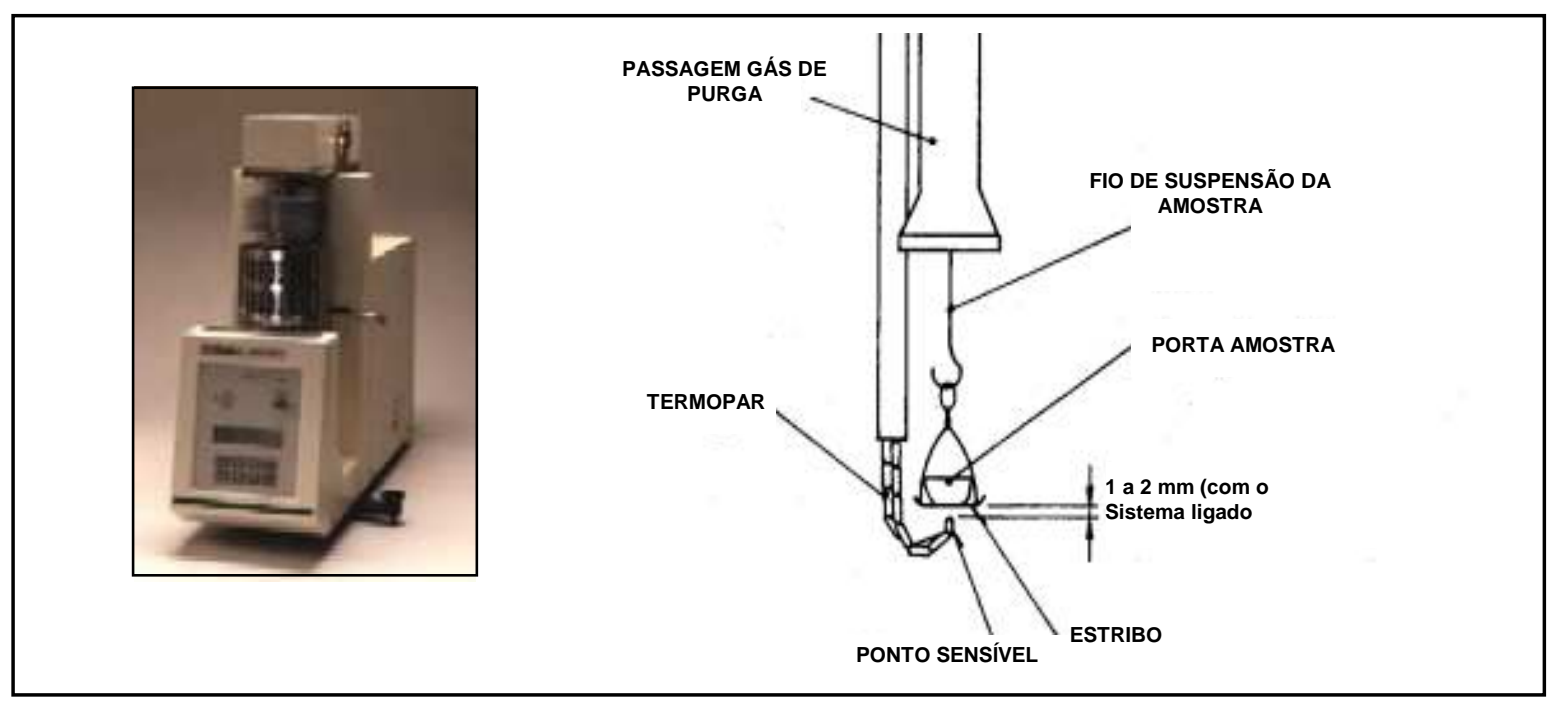

Figura 6: Representação fotográfica da termobalança modelo TGA 50 (SHIMADZU, 2004) e esquema da estrutura de colocação do porta-amostra.

\subsubsection{Estudo da Estabilidade de produtos cosméticos}

O estudo da estabilidade de produtos cosméticos fornece informações que indicam o grau de estabilidade relativa de um produto nas variadas condições a que possa estar sujeito desde sua fabricação até o término de sua validade. Essa estabilidade é relativa, pois varia com o tempo e em função de fatores que aceleram ou retardam alterações nos parâmetros do produto. Modificações dentro de limites determinados podem não configurar motivo para reprovar o produto. $O$ estudo da estabilidade de produtos cosméticos contribui para orientar o desenvolvimento da formulação e do material de acondicionamento adequado, fornecer subsídios para o aperfeiçoamento das formulações, estimar o prazo de validade e fornecer informações para a sua confirmação, auxiliar no monitoramento da estabilidade organoléptica, físico-química e microbiológica, produzindo informações sobre a confiabilidade e segurança.

Os parâmetros a serem avaliados devem ser definidos pelo formulador e dependem das características do produto em estudo e dos ingredientes utilizados na formulação. De modo geral, avaliam-se: 
- Parâmetros Organolépticos: aspecto, cor, odor e sabor, quando aplicável;

- Parâmetros Físico-Químicos: valor de pH, viscosidade, densidade, e em alguns casos, o monitoramento de ingredientes da formulação;

- Parâmetros Microbiológicos: contagem microbiana e teste de desafio do sistema conservante (Challenge Test).

\subsection{Teste de centrifugação}

Antes de iniciar os Estudos de Estabilidade, recomenda-se submeter o produto ao teste de centrifugação. Sugere-se centrifugar uma amostra a $3.000 \mathrm{rpm}$ durante 30 minutos. O produto deve permanecer estável e qualquer sinal de instabilidade indica a necessidade de reformulação. Se aprovado nesse teste, o produto pode ser submetido aos testes de estabilidade.

\subsection{Estudo da Estabilidade acelerada}

Tem como objetivo fornecer dados para prever a estabilidade do produto, tempo de vida útil e compatibilidade da formulação com o material de acondicionamento.

Geralmente tem duração de noventa dias e as formulações em teste são submetidas a condições menos extremas que no teste de Estabilidade Preliminar. Em alguns casos, a duração deste teste pode ser estendida por seis meses ou até um ano, dependendo do tipo de produto. As amostras podem ser submetidas a aquecimento em estufas, resfriamento em refrigeradores, exposição à radiação luminosa e ao ambiente.

Os valores geralmente adotados para temperaturas elevadas são:

Estufa: $\mathrm{T}=37 \pm 2,0^{\circ} \mathrm{C} ; \mathrm{T}=40 \pm 2,0^{\circ} \mathrm{C} ; \mathrm{T}=45 \pm 2,0^{\circ} \mathrm{C}$ ou $\mathrm{T}=50 \pm 2,0^{\circ} \mathrm{C}$

Os valores geralmente adotados para baixas temperaturas são:

Geladeira: $T=5 \pm 20^{\circ} \mathrm{C}$, ou Freezer: $T=-5 \pm 20^{\circ} \mathrm{C}$, o u $\mathrm{T}=-10 \pm 20^{\circ} \mathrm{C}$

Exposição à Radiação Luminosa

A radiação luminosa pode alterar significativamente a cor e o odor do produto e levar à degradação de componentes da formulação. Para a realização deste 
estudo a fonte de iluminação pode ser a luz solar, captada através de vitrines especiais para este fim, ou lâmpadas que apresentem espectro de emissão semelhante à do sol, como as lâmpadas de xenônio. Também são utilizadas fontes de luz ultravioleta.

A periodicidade da avaliação das amostras pode variar conforme experiência técnica, especificações do produto, características especiais de algum componente da formulação ou sistema conservante utilizado, porém o mais usual neste estudo acelerado é que sejam avaliadas inicialmente no tempo zero, 24 horas e aos $7^{\circ}, 15^{\circ}$, $30^{\circ}, 60^{\circ}$ e $90^{\circ}$ dias. Se o estudo se prolongar por $\mathrm{m}$ ais tempo, recomendam-se avaliações mensais até seu término.

Os parâmetros a serem avaliados devem ser definidos pelo formulador, dependem das características da formulação em estudo e dos componentes utilizados nesta formulação. De modo geral, avaliam-se:

- Características organolépticas: aspecto, cor, odor e sabor, quando aplicável;

- Características físico-químicas: valor de $\mathrm{pH}$, viscosidade e densidade, entre outros;

- Características microbiológicas: estudo do sistema conservante do produto por meio do teste de desafio efetuado antes e ou após o período de estudo acelerado.

\subsubsection{Cromatografia em fase gasosa (CG)}

Cromatografia gasosa é uma forma de partição cromatográfica, em que os compostos a serem separados são volatilizados e, através do gás inerte (fase móvel), passam pela coluna onde um líquido de alto ponto de ebulição (fase estacionária) é depositado em um suporte sólido. O uso de temperaturas convenientes no local de injeção possibilita a vaporização da amostra.

As substâncias são separadas de acordo com os seus coeficientes de partição, que são dependentes das suas volatilidades e solubilidades relativas na fase líquida. Os ácidos graxos emergem da coluna em tempos diferentes que são detectados por meios que convertem a concentração do componente na fase gasosa em um sinal elétrico, que por sua vez é amplificado e registrado. 
A escolha da fase é o parâmetro mais importante na separação cromatográfica. Esta deve ter características físico-químicas semelhantes às da amostra.

Em colunas não polares os ésteres metílicos de ácidos graxos são eluídos em ordem crescente de seus pontos de ebulição e os compostos insaturados eluem antes de seus correspondentes saturados do mesmo comprimento de cadeia. As fases estacionárias não-polares mais comumente usadas na cromatografia gasosa de alimentação são: metilsilicona, metilsilicona com $1 \%$ vinil e $5 \%$ fenil; dimetilpolisiloxana (100\%), 95\% dimetil, 5\% difenilpolisiloxana.

\subsection{Análise de ácidos graxos por Cromatografia em fase gasosa}

A cromatografia gasosa tem sido amplamente utilizada na análise dos ácidos graxos em óleos e gorduras (CURI, 2002). Este método permite a separação dos ácidos graxos de cadeia curta sem a necessidade de passos de derivatização. No entanto, o mesmo não é o que acontece com os ácidos graxos de cadeia longa, onde por apresentarem baixa volatilidade requerem etapa de derivatização, onde os grupos carboxílicos são convertidos em grupos mais voláteis como o trimetilsililésteres ou metil-ésteres (HERNANDEZ et al., 1988; SHIN, et al, 1853).

O detector de ionização por chama (Flame Ionization Detection-FID) é muito utilizado na detecção de compostos orgânicos. As substâncias sofrem pirólise na chama hidrogênio-oxigênio e produzem íons no processo. Os gases transportadores são nitrogênio, o hélio, ou hidrogênio. O hidrogênio é o mais utilizado devido sua rapidez nas análises e uma melhor separação das substâncias.

Exemplos de detecção com detector de ionização de chama em análises de CG são inúmeras. Este detector é o mais útil na análise dos derivados de ácidos graxos COCITO \& DELFINI (1994), WOLFF \& FABIEN 1989.

$\mathrm{Na}$ análise por CG, é importante que as substâncias ou misturas de substâncias sejam voláteis ou volatilizadas. É difícil analisar ácidos graxos diretamente por CG por causa da alta polaridade, baixa volatilidade, e porque formam pontes de hidrogênio. O ponto de ebulição à pressão atmosférica e o alto peso molecular dos ácidos graxos tem valor próximo à temperatura de decomposição da substância, ou até mesmo superiores. Portanto, a derivatização de 
ácidos graxos para análises em CG é efetuada de modo a aumentar a volatilidade das substâncias para melhorar a separação (SAKODYNSKY, 1979).

Bressani e Gutierrez estudaram a composição de ácidos graxos presentes no óleo da Castanha do Brasil e em ambos estudos o óleo foi obtido por prensagem (Tabela 4), não se observando grandes diferenças nestes teores. Na composição do óleo de Castanha do Brasil destacam-se os altos teores dos ácidos palmítico (12$15 \%)$, esteárico $(8,7-10,4 \%)$, oléico $(27,2-41,2 \%)$ e linoléico $(34,0-49,9 \%)$ (Tabela 4$)$ (Bressani, 1961; Gutierrez et al.,1997).

Venkatachalam et al em 2006 determinaram ácidos graxos presentes no óleo de Castanha do Brasil (Tabela 4).

Ryan et al também estudaram, em 2006, o teor de ácidos graxos e tocoferóis presentes no óleo extraído das Castanhas do Brasil, noz, pinho, pistache e caju. Eles encontraram valores semelhantes àqueles encontrados por Venkatachalam et al. A técnica de análise empregada para quantificar o teor de ácidos graxos em ambos os estudos foi a cromatografia gasosa. Observa-se que em todos os casos o teor de ácido linoléico é maior (seguindo o ácido oléico exceto para o estudo de Silva et al., 1997) (Tabela 4).

Tabela 4: Composição de ácidos graxos do óleo da Castanha do Brasil estudados por diferentes autores, analisados pelos métodos de cromatografia em fase gasosa.

\begin{tabular}{|c|c|c|c|c|c|c|c|}
\hline $\begin{array}{c}\text { AG } \\
(\%)\end{array}$ & $\begin{array}{c}\text { Elias \& } \\
\text { Bressani } \\
(\mathbf{1 9 6 1 )}\end{array}$ & $\begin{array}{c}\text { Melo \& } \\
\text { Mancini } \\
\mathbf{( 1 9 9 1 )}\end{array}$ & $\begin{array}{c}\text { Gutierrez } \\
\text { et al. } \\
\mathbf{( 1 9 9 7 )}\end{array}$ & $\begin{array}{c}\text { Silva } \\
\text { et al. } \\
(\mathbf{1 9 9 7})\end{array}$ & $\begin{array}{c}\text { Solis } \\
\text { et al. } \\
\mathbf{( 2 0 0 1 )}\end{array}$ & $\begin{array}{c}\text { Venkatachalam } \\
\text { et al. (2006) }\end{array}$ & $\begin{array}{c}\text { Ryan } \\
\text { et al. } \\
\mathbf{( 2 0 0 6 )}\end{array}$ \\
\hline $16: 0$ & 13,9 & 14,5 & 13,9 & 15,20 & 15,20 & 15,11 & 13,50 \\
\hline $18: 0$ & 10,3 & 8,3 & 8,1 & 8,80 & 11,60 & 9,51 & 11,77 \\
\hline $18: 1$ & 30,5 & 27,2 & 29 & 40,90 & 34,50 & 28,75 & 29,09 \\
\hline $18: 2$ & 44,9 & 49,9 & 48,8 & 34,00 & 37,80 & 45,43 & 42,8 \\
\hline
\end{tabular}

\subsubsection{Cromatografia em fase líquida de alta eficiência (CLAE)}

A cromatografia pode ser conceituada como um método físico-químico de separação, no qual os constituintes da amostra a serem separados são particionados em duas fases, uma estacionária, geralmente de grande área, e a outra um fluído insolúvel na fase estacionária, que percorre a primeira. A fase estacionária, ou adsorvente, tem tomado várias formas no decorrer do tempo, 
incluindo papel, camada delgada de sólidos sobre placa de vidro, líquidos imobilizados, géis e partículas sólidas empacotadas em colunas. O componente que flui, ou fase móvel, é um líquido ou um gás (WESTON \& BROWN, 1997).

$\mathrm{Na}$ cromatografia de alta eficiência, surgida na década de 60 , a enorme variedade de fases estacionárias disponíveis (colunas) e a ampla faixa de temperatura utilizada permitem uma grande variação no tipo de interação específica, multiplicando as possibilidades de separação. $O$ método permite o uso de vários tipos de detectores: UV-VIS, PDA, eletroquímico, fluorescência, índice de refração, espectrometria de massas, etc (SNYDER, KIRKLAND \& GLAJCH, 1997).

\subsection{Análise de ácidos graxos por cromatografia em fase líquida}

Em princípio, os ácidos graxos podem ser separados por cromatografia em fase líquida de alta eficiência em fase reversa, apesar da baixa absortividade molar dos ácidos graxos tornar a quantificação direta por detecção UV difícil em amostras reais. Detectores alternativos têm sido propostos na literatura, como índice de refração (TISELIUS, 1942; KING, 1982), detector de condutividade (KING, 1982), fluorescência (TSUYAMA, 1992) e quimioluminescência (YOO, 1992). Nas análises com deteç̧ão por absorbância, há necessidade de derivatização visando a formação de adutos ou derivados que apresentem alta absortividade, como fenacil ésteres (KAWASAKI, 1990), naftacil ésteres (DURST, 1797) e 2-nitrofenilhidrazidas (JORDI, 1978).

Nishiyama-Nakure et al, 1998, estudaram os ácidos graxos extraídos dos óleos de soja, de coco, manteiga de cacau e tecidos de ratos e descreveram um método alternativo em que duas técnicas desenvolvidas separadamente foram combinadas: a saponificação dos lipídeos em temperatura baixa e a quantificação dos ácidos graxos por HPLC. Os ácidos graxos foram separados em uma coluna de fase-reversa e identificados por um detector de índice de refração. O estudo verificou a viabilidade do uso da técnica de HPLC para a quantificação de ácidos graxos. A vantagem deste método é que durante a manipulação e a detecção, os ácidos graxos não são expostos às altas temperaturas, diminuindo a possibilidade de oxidação e racemização. 
No presente trabalho, os ácidos graxos do óleo de Castanha do Brasil foram caracterizados pelo método de CLAE, modo fase reversa e método isocrático. Este método é o mais utilizado para ensaios de compostos bioquímicos e farmacêuticos e tem sido amplamente utilizado para análises de ácidos graxos. $\mathrm{Na}$ literatura, são encontrados diversos trabalhos com diferentes reagentes utilizados para derivatização de ácidos graxos para suas análises. Dentre eles, destaca-se o 4Bromo-metil-7-metoxi-coumarina (BrMMC) (WOLF \& KORF, 1992). O mecanismo da reação de derivatização de um ácido carboxílico com BrMMC é dada na figura 6 . Basicamente, um sal do ácido graxo, comumente um sal de potássio, é formado sob refluxo em um solvente aprótico. Este sal reage então com o marcador BrMMC. Lam e Grushka (1978) utilizaram o éter de coroa para acelerar o processo de solubilização de sais de potássio. Este catalisador tem dimensões específicas para a captura ideal do íon potássio (GOKEL \& DURST, 1976).

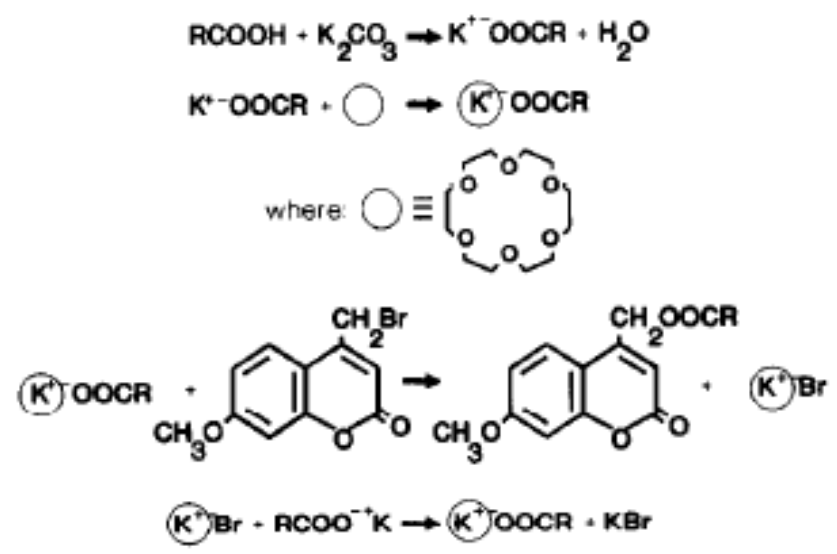

Figura 7: Esquema da reação de derivatização com BrMMC na presença do éter de coroa.

\subsubsection{Eletroforese capilar (EC)}

A eletroforese capilar (CE) é uma técnica de separação em fase líquida que se baseia na migração diferencial de espécies iônicas ou ionizáveis quando as mesmas são submetidas a um campo elétrico (TAVARES, 1996). 


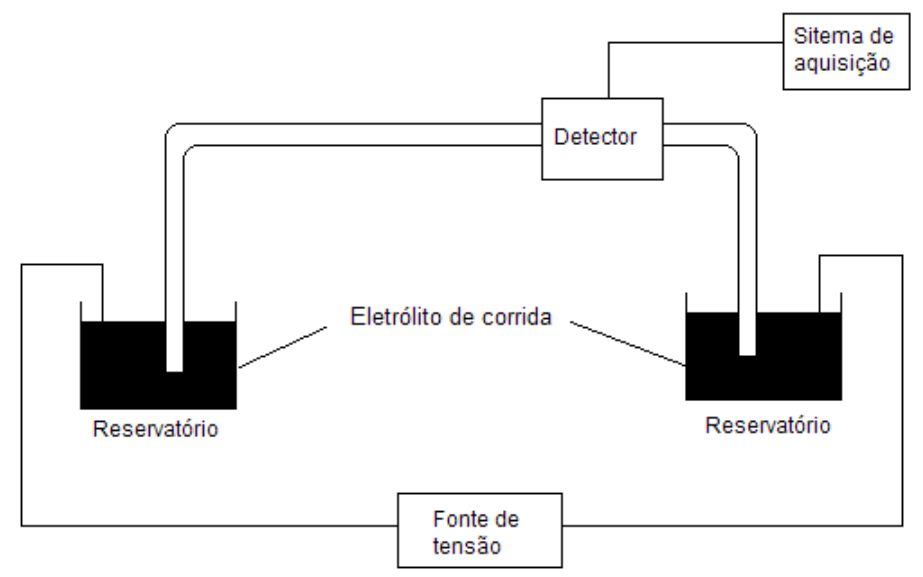

Figura 8: Configuração Básica do sistema de Eletroforese Capilar

É realizada preenchendo o capilar e reservatórios com um eletrólito, usualmente uma solução tampão aquosa. Em uma das extremidades é introduzida a amostra. Quando é aplicada uma diferença de potencial, gera um campo elétrico entre as extremidades que causa um movimento das partículas carregadas (TAVARES, 1996; BAKER, 1995). A instrumentação consiste em um fornecedor de alta voltagem, capilar de diâmetro estreito $(25-100 \mu \mathrm{m})$, eletrodos (geralmente de platina) e um detector apropriado. A aplicação de um potencial de 10-30 kV sobre o capilar provoca movimentos eletroforéticos e eletrosmóticos, resultando em movimento das espécies iônicas da amostra ao longo do capilar e passando através do detector. A passagem pelo detector é chamada de eletroferograma (ALTRIA, 1996).

A habilidade de obter alta eficiência de separação por aplicação de diferença de potencial através de um capilar (ALTRIA, 1999), foi introduzida em 1981, por Jorgenson e Lukacs (ANDRADE e CUSTÓDIO, 2005). Por ser ecologicamente mais correta e mais econômica (VEUTHEY, 2005) é a técnica de separação de mais rápida expansão em análises farmacêuticas (WATSON, 1999), gradualmente se estabelece como uma técnica alternativa e de suporte para CLAE (ALTRIA, 1999). EC já é utilizada na rotina em análises farmacêuticas, forenses, clínicas e ambientais, mas sua utilização tornou-se mais evidente com o projeto genoma humano e o seqüenciamento de proteínas (ALTRIA, 2004). 


\subsection{Princípios da eletroforese capilar}

O processo de separação se dá pela aplicação da voltagem, de tal forma que cátions migram para o pólo negativo (cátodo) e anions para o pólo positivo (ânodo), e partículas neutras não são atraídas para nenhum dos pólos (United States Pharmacopeia, 2002).

A mobilidade eletroforética de uma espécie química é em geral determinada pelo seu tamanho e número de cargas dos íons e pode ser calculada segundo a relação:

$\mu \mathrm{E}=(\mathbf{q} / 6 \pi) / \eta \mathbf{r}$

Onde: $\mu \mathrm{E}=$ mobilidade eletroforética; $q=$ carga; $\eta=$ viscosidade da solução e $r=$ raio do íon.

A mobilidade dos íons do soluto depende do tamanho das partículas, seguido do número de cargas iônicas. Sendo assim um íon muito pequeno movimenta-se mais rapidamente do que um maior, com o mesmo número de cargas.

Hipoteticamente, para separar íons com diferentes cargas e tamanhos, o menor e de maior carga sairá antes. A velocidade eletroforética, depende da diferença de potencial aplicada, seguindo a seguinte relação (ALTRIA, 1996):

\section{$v=\mu \mathrm{E}$}

Onde: $\mathrm{v}=$ velocidade do íon e $\mathrm{E}=\mathrm{ddp}$ aplicada (volts $/ \mathrm{cm}$ )

A mobilidade de um íon pode ser influenciada pelo seu valor de $\mathrm{pKa}$, assim quanto mais ionizado maior será sua mobilidade, por este motivo a manipulação do $\mathrm{pH}$ tem um efeito marcante na mobilidade relativa dos íons (WATSON, 1999). O fator mais importante na separação por EC é o Fluxo eletro-osmótico.

\subsection{Fluxo eletro-osmótico}

Este fluxo ocorre pela ionização dos grupos silanois da sílica (parede dos capilares) quando em contato com solução tampão. Em valores de pH muito altos, estes grupos dissociam resultando em cargas negativas (grupos silanoatos) na superfície (ALTRIA, 1996). Os grupos silanoatos atraem íons carregados positivamente provenientes do tampão, que formam uma camada interna de cátions (camada fixa) perto da parede do capilar. Estes cátions não são suficientes para neutralizar todas as cargas negativas, assim, uma segunda camada de cátions é 
formada (camada móvel). Quando uma tensão é aplicada, a camada móvel é puxada no sentido do cátodo. As moléculas de água que solvatam o analito também contribuem para o deslocamento deste ao longo do capilar. Esta força, responsável pelo transporte das espécies iônicas ao longo do capilar, é denominada Fluxo eletroosmótico (FEO) (SANTORO et al., 2000).

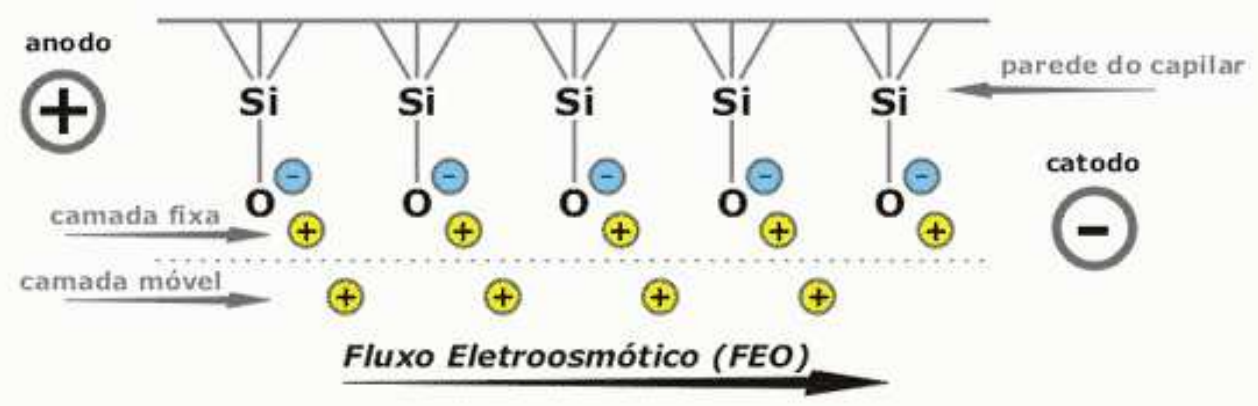

Figura 9: Esquema mostrando a formação e o sentido do fluxo eletro-osmótico (fonte: QUEIROZ; JARDIM, 2005).

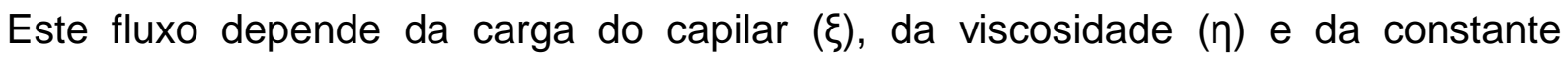
dielétrica do tampão $(\varepsilon)$.

$\mu \mathrm{FEO}=\varepsilon \xi / \eta$

Portanto, o fluxo eletro-osmótico depende diretamente do $\mathrm{pH}$ do eletrólito, pois a

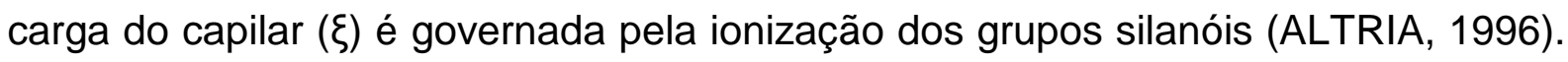
Com incremento de $\mathrm{pH}$ de três para oito, o fluxo eletro-osmótico ( $\mu \mathrm{FEO}$ ) pode ser aumentado até 10 vezes (WATSON, 1999), em valores de pH menores que dois não há fluxo eletro-osmótico, pois a maior parte dos grupos silanóis está protonado (BAKER, 1995). A alta concentração de anions no tampão quando a temperatura é controlada leva a um decréscimo do fluxo eletro-osmótico (BAKER, 1995), pois reduzem a interação das moléculas de água com as paredes do capilar (WATSON, 1999). A adição de modificadores como solventes orgânicos têm efeito variável, pois afetará a viscosidade, constante dielétrica e potencial $Z$, a influência deste dependerá também da concentração adicionada; por exemplo, adicionar metanol à água aumenta a viscosidade da solução até a concentração de $50 \%(\mathrm{v} / \mathrm{v})$, a partir de então decresce até $100 \%$ de metanol (BAKER, 1995). 


\subsection{Técnicas de eletroforese capilar}

A eletroforese capilar, na verdade, não é uma única técnica isolada, ela deve ser encarada como uma família de técnicas fundamentadas no mesmo princípio de migração sob ação de um campo elétrico, mas com mecanismos de separação diferentes (TAVARES, 1997):

1. Eletroforese capilar de zona ou solução livre

2. Cromatografia eletrocinética micelar (MECC);

3. Eletroforese capilar por focalização isoelétrica (CIEF);

4. Eletroforese capilar de gel (CGE);

5. Isotacoforese (CITP);

6. Eletrocromatografia (CEC).

Deve-se ressaltar que a EC pode oferecer vantagens significativas sobre as técnicas cromatográficas. Dentre elas destacam-se: requisição de pequeno volume de amostra, utilização de deteç̧ão por absorção da luz ultravioleta em comprimentos menores do que $200 \mathrm{~nm}$ sem que haja aumento no ruído ou drift de linha de base (problema comum em CLAE), análise de uma vasta gama de compostos desde íons até macromoléculas utilizando a mesma coluna capilar. Os instrumentos de EC e CLAE convencionais possuem custo equivalente, mas o custo operacional é significativamente menor na EC, principalmente pelo baixo consumo de solventes e com baixo custo das colunas capilares (PERRETT, 2003; PICÓ et al., 2003; ANASTOS et al., 2005).

Eletroforese capilar já é utilizada na rotina em análises farmacêuticas, forenses, clínicas e ambientais, mas sua utilização tornou-se mais evidente com o projeto genoma humano e o sequênciamento de proteínas (ALTRIA, 2004).

Cromatografia eletrocinética micelar (MEKC)

A cromatografia eletrocinética micelar foi introduzida por Terabe e colaboradores em 1984, voltada para a separação de misturas contendo solutos neutros. Em MEKC, agentes tensoativos iônicos (dodecilsulfato de sódio - SDS), em condições favoráveis a formação de micelas são adicionadas ao eletrólito de corrida, proporcionando um sistema de cromatográfico de duas fases. Desse modo o 
eletrólito representa a fase primária, a qual é transportada eletrosmoticamente pela ação do campo elétrico, enquanto que as micelas que representam a fase secundária são transportadas pela combinação de eletroforese e eletrosmose. A partição diferenciada de solutos neutros entre as duas fases é responsável pela seletividade da separação (SILVA et al., 2007).

\subsection{Análise de ácidos graxos por Eletroforese capilar}

Ácidos graxos não possuem fortes grupos cromóforos em suas estruturas e este fato impede sua sensibilidade à detecção fotométrica direta. Uma solução para este problema foi fornecida pela introdução da detecção UV indireta e fluorescência indireta em eletroforese capilar há bem mais de uma década atrás para a detecção sensível de compostos com ausência de grupos cromóforos e fluoróforos (YEUNG, 1995).

Recentemente, a eletroforese capilar tem sido largamente investigada na análise de ácidos graxos. Muitos cromóforos têm sido propostos, incluindo o panisato (MIWA et al., 1987), dietilbarbiturato (ROLDAN-ASSAD et al., 1995) e benzenosulfonato (BUEHBERGER et al., 1996; OLIVEIRA et al., 2001).

Uma das principais preocupações em analisar ácidos graxos livres por eletroforese capilar tem sido limitada à sua solubilidade em sistemas eletrólitos aquosos. Este problema já foi superado através da introdução eletroforese capilar não aquosa (NACE) há mais de uma década (SAHOTA \& KHALEDI, 1994), sistemas parcialmente aquosos tem sido utilizado na separação de ácidos graxos saturados e insaturados (DRANGE et al., 1997; HADDADIAN, 1999) e 100\% de metanol com $12,5 \mathrm{mM}$ cloreto de tetraetilamônio (GALLAHER et al., 2000) foram eficientes na separação de alguns ácidos graxos de cadeia longa ( $\geq \mathrm{C} 16)$.

Haddadian e colaboradores demonstraram o poder do polioxietileno lauril éter (Brij 35) para a separação dos ácidos graxos saturados $\mathrm{C}_{12}-\mathrm{C}_{31}$ diferenciando-se por um carbono em suas cadeias, em um tampão contendo Tris $40 \mathrm{mM}$, N-metilformídeodioxano (3:2), 0,5\% (w/v) Brij 35 e 2.5mM adenosina monofosfato.

Alguns estudos obtiveram sucesso na separação de ácidos graxos realizada por sistemas eletrólitos parcialmente aquosos contendo 60\% ACN (GUTNIKOV et al., 1994), 60\% de metanol (ROLDAN-ASSAD et al., 1995), mistura de $10 \mathrm{mM}$ de dodecilbenzenosssulfonato de sódio (SDBS), 50\% ACN, e Brij 35 (ERIM et al., 1995), 
ou da mistura de $4 \mathrm{mM}$ SDBS, $10 \mathrm{mM}$ Brij 35, 2\% de 1-octanol, e 45\% ACN (OLIVEIRA et al., 2003).

Oliveira e colaboradores estudaram uma metodologia para analisar ácidos graxos utilizando eletroforese capilar com detecção indireta (224 nm). O eletrólito consistiu de um tampão fosfato $5 \mathrm{mmol}^{-1}, \mathrm{pH} \mathrm{7,} \mathrm{contendo,} \mathrm{SDBS} \mathrm{como} \mathrm{cromóforo} 4$ $\mathrm{mmol}^{-1}$, dimetil- $\beta$-ciclodextrina $4 \mathrm{mmol}^{-1}$ e $45 \%$ acetonitrila. Os autores separaram nove ácidos graxos de $\mathrm{C}_{10}$ a $\mathrm{C}_{20}$ : cáprico, láurico, mirístico, palmítico, esteárico, araquídico, cis-oléico, cis-linoléico e cis-linolênico em menos de 10 minutos. O método proposto foi aplicado para ácidos graxos dos óleos extraídos de sementes e margarina (OLIVEIRA et al., 2001)

Oliveira e colaboradores descreveram um novo método para separação de ácidos graxos de $\mathrm{C}_{8} \quad \mathrm{a}_{20}$ do óleo vegetal de coco utilizando eletroforese capilar com detecção condutométrica sem contato. A completa separação de ácidos graxos de cadeia linear ocorreu em 15 minutos de operação com polaridade normal. $O$ sistema eletrólito foi tampão fosfato 5.0 mmol. $\mathrm{L}^{-1}, \mathrm{pH} 7$, dimetil- $\beta$-ciclodextrina 4.0 mmol. $\mathrm{L}^{-1}$, trimetil- $\beta$-ciclodextrina $2.0 \mathrm{mmol} . \mathrm{L}^{-1}$, acetonitrila $50 \%(\mathrm{v} / \mathrm{v})$, e metanol $20 \%$ (v/v) (OLIVEIRA et al., 2003).

Bannore e colaboradores demonstraram pela primeira vez a adequação da eletroforese capilar utilizando um sistema eletrólito parcialmente aquoso para análise de ácidos graxos livres presentes na semente do amendoim. O comportamento de cinco ácidos graxos padrões que são comuns na maioria dos óleos, ou seja, palmítico, esteárico, oléico, linoléico e linolênico foi inicialmente investigado em eletroforese capilar no âmbito de vários sistemas eletrólitos não aquosos e parcialmente aquosos, a fim de alcançar uma base separação para estes ácidos. A parte aquosa do sistema eletrólito consistiu de $40 \mathrm{mM}$ Tris, 2,5 mM adenosina-5monofosfato (AMP) e $7 \mathrm{mM}$ de $\alpha$-CD em uma mistura de ( $N$-metilformamida) NMF/dioxano/água (5:3:2 em volume), $\mathrm{pH}$ 8-9. Enquanto a AMP serviu para permitir a detecção UV indireta dos ácidos graxos livres, a $\alpha$-CD funcionou como um modulador de seletividade afetando as mobilidades relativas efetivas eletroforéticas dos vários ácidos graxos devido à sua associação diferencial com $\alpha$-CD. Este método de eletroforese capilar permitiu a análise de sementes de amendoim quanto ao seu teor de ácidos oléico e linoléico (BANNORE et al., 2008). 
Uma metodologia de Eletroforese Capilar usando detecção UV indireta (224 $\mathrm{nm}$ ) foi proposta por Oliveira para analisar ácidos graxos trans formados durante a hidrogenação do óleo de Castanha do Brasil (Tabela 5) (Oliveira et al., 2003).

Moraes também estudou a hidrólise do óleo de Castanha do Brasil com resina de troca catiônica e determinou os ácidos graxos encontrados no óleo de Castanha do Brasil utilizando o método de eletroforese capilar (Tabela 5) (Moraes, 2004).

Tabela 5: Concentração de ácidos graxos presentes na Castanha do Brasil obtida pelo método de Eletroforese Capilar obtida por Moraes (2004).

\begin{tabular}{|l|c|c|}
\hline \multirow{2}{*}{ Ácido graxo } & Oliveira et al (2003) & Moraes (2004) \\
\cline { 2 - 3 } & $\%(\mathbf{m} / \mathbf{m})$ & $\%(\mathbf{m} / \mathbf{m})$ \\
\hline Ácido palmítico (C16:0) & 13,4 & 8,1 \\
\hline Ácido esteárico (C18:0) & 7,00 & 2,2 \\
\hline Ácido oléico (C18:1) & 37,4 & 17,6 \\
\hline Ácido linoléico (C18:2) & 42,2 & 22,3 \\
\hline Ácido linolênico (C18:3) & ------ & 1,9 \\
\hline
\end{tabular}




\section{OBJETIVOS}

GERAL

Identificar e avaliar os ácidos graxos utilizando diferentes técnicas analíticas.

\section{ESPECÍFICOS}

- Identificar os ácidos graxos presentes no óleo de Castanha do Brasil empregando as seguintes técnicas analíticas; cromatografia em fase gasosa (CG), cromatografia em fase líquida (CLAE), eletroforese capilar, calorimetria exploratória diferencial (DSC) e termogravimetria (TG)/termogravimetria derivada (DTG).

- Definir e desenvolver uma formulação cosmética para a incorporação do óleo de Castanha do Brasil.

- Avaliar a estabilidade física da formulação baseada na avaliação dos caracteres organololépticos, $\mathrm{pH}$ e viscosidade.

- Estudo do comportamento térmico da formulação base (sem a incorporação do óleo de Castanha do Brasil) e da formulação com a incorporação do óleo de Castanha do Brasil utilizando as técnicas de termogravimetria/termogravimetria derivada (TG/DTG).

- Determinar o prazo de validade do óleo de Castanha do Brasil utilizando as técnicas de termogravimetria.

- Desenvolver um método analítico utilizando a eletroforese capilar com o intuito de identificar os ácidos graxos presentes no óleo de Castanha do Brasil, em associação com as formulações cosméticas. 


\subsection{MATERIAL}

4.1.1. Matérias-primas empregadas no desenvolvimento das formulações

\subsubsection{Umectante}

A Glicerina Bi-Destilada ${ }^{\circledR}$ foi adquirida da empresa Mapric, apresentando grau de pureza farmacêutico. As especificações da Glicerina Bi-Destilada ${ }^{\circledR}$ segundo certificado de análise fornecido pela Mapric são as seguintes:
a) INCl: Glycerin;
b) Aspecto $\left(25^{\circ} \mathrm{C}\right)$ : líquido viscoso.
c) Cor: amarelo alaranjado.
d) Odor: característico.
e) Densidade ( $\left.\mathrm{T}=25^{\circ} \mathrm{C}\right): 1,26 \mathrm{~g} / \mathrm{cm}^{3}$.

\subsubsection{Emulsionante polimérico}

O Sepige $\left.\right|^{\circledR} 305$ foi adquirido da empresa Mapric apresentando grau de pureza farmacêutico. É utilizado como polímero emulsionante, espessante e estabilizante para emulsões e géis creme. As especificações do Sepigel ${ }^{\circledR} 305$ segundo certificado de análise fornecido pela Mapric são as seguintes:
a) INCl: Polyacrylamide (and) $C_{13-14}$ Isoparaffin (and) Laureth-7;
b) Aspecto $\left(25^{\circ} \mathrm{C}\right)$ : emulsão fluída.
c) Cor: branca.
d) Viscosidade aparente (solução à 2\%): 60.000 - 90.000 mPas.s.
e) $\mathrm{pH}: 6,0$.

\subsubsection{Tensoativo não iônico hidrossolúvel}

Uma das principais razões para o uso de tensoativos não-iônicos em produtos para a pele é sua bem documentada segurança, em especial sua excelente tolerância pela pele e olhos (IDSON, 1997). À frente dos agentes emulsivos iônicos, os nãoiônicos (que não formam íons em meio aquoso) apresentam vantagens essenciais que justificam seu crescente uso em dermo-formulações.Tem reação neutra, são pouco influenciáveis por eletrólitos e se apresentam bastante inertes frente a 
diferentes reações químicas. Possuem atividade indiferente á variações de temperatura (VOIGT, 1982).

O Procetyl ${ }^{\circledR}$ AWS foi adquirida da empresa Mapric, apresentando grau de pureza farmacêutico. Sóluvel em álcool; emoliente; solubilizante de essências; molhante; sobreengordurante, antiestático e condicionador para cabelos. As especificações do Procetyl ${ }^{\circledR}$ AWS segundo certificado de análise fornecido pela Mapric são as seguintes:

a) INCI: PEG-5 Ceteth-20.

b) Dosagem/ concentração: 0,5-5,0\%.

c) Aspecto $\left(25^{\circ} \mathrm{C}\right)$ : líquido incolor.

\subsubsection{Quelante}

O EDTA foi adquirido da empresa Mapric, apresentando grau de pureza farmacêutico. É um pó cristalino branco inodoro ou com pouco odor. Solúvel em 1:11 de água; ligeiramente solúvel em álcool e praticamente insolúvel em clorofórmio e éter. Possui propriedade quelante e também de antioxidante sinérgico. As especificações do EDTA segundo certificado de análise fornecido pela Mapric são as seguintes:

a) INCI: Dissodium EDTA.

b) Aspecto $\left(\mathrm{T}=25^{\circ} \mathrm{C}\right)$ : cristais.

c) Cor: branco.

d) $\mathrm{pH}(\mathrm{T}=25 \stackrel{\circ}{ } \mathrm{C})$ solução a $5 \%: 4,4$.

\subsubsection{Conservante}

O Phenoben ${ }^{\circledR}$ foi adquirido da empresa Mapric apresentando grau de pureza farmacêutico. É um agente conservante de largo espectro de ação contra fungos, leveduras e bactérias. É uma solução de parabenos (metilparabeno, propilparabeno, etilparabeno, butilparabeno) em fenoxietanol. Ele é compatível com a maioria dos compostos químicos, não causando alterações de cor, viscosidade, $\mathrm{pH}$ e odor, sendo compatível com sistemas aniônicos e mantém sua ação em condições de pH ácido, neutro e alcalino. As especificações do Phenoben $^{\circledR}$ segundo certificado de análise fornecido pela Mapric são as seguintes:

a) INCl: sendo o Phenoben uma solução contendo ésteres de parabenos em fenoxietanol. Os ésteres de parabenos presentes na solução apresentam os 
seguintes INCI: Phenoexyethanol, Methylparaben; Ethylparaben; Propylparaben e Butylparaben;

Aspecto $\left(\mathrm{T}=25^{\circ} \mathrm{C}\right)$ : líquido de baixa viscosidade transparente;

b) Cor: incolor.

c) Odor: característico suave.

d) Densidade ( $\left.\mathrm{T}=25^{\circ} \mathrm{O}\right): 1,115 \mathrm{~g} / \mathrm{cm}^{3}$.

e) Índice de Refração ( $\left.T=25^{\circ} \mathrm{C}\right): 1,500$.

f) Contagem microbiana: bactérias: máximo $100 \mathrm{col} / \mathrm{g}$.

g) Contagem microbiana: fungos: máximo $100 \mathrm{col} / \mathrm{g}$.

\subsubsection{Veículo}

A Água destilada foi o veículo empregado para as formulações desenvolvidas.

\subsubsection{Emolientes}

I. Silicone DC ${ }^{\circledR} 1411$ foi adquirido da empresa Mapric apresentando grau de pureza farmacêutico. Maciez, toque seco e condicionante; misturas contendo gomas de silicone; consiste em misturas de silicone de ultra-alta viscosidade em fluidos de baixa viscosidade. Estes produtos fornecem espalhamento, suavidade $e$ substantividade. Funciona como um veículo de goma substantiva de alto peso molecular e rapidamente se evapora sem resfriar a pele, deixando a pele seca e com uma sensação refrescante como o talco promovido pelo polidimetilsiloxano. Oferece uma sensação macia e seca similar aquela oferecida por um talco.
a) INCl: Cyclomethicone (and) Dimethicone
b) Aspecto ( $\left.T=25^{\circ} \mathrm{C}\right)$ : líquido.
c) Cor: incolor.
d) Odor: característico.

II. Silicone DC ${ }^{\circledR} 9040$ foi adquirido da empresa Mapric apresentando grau de pureza farmacêutico. Esse componente foi desenvolvido para sobrepor as limitações de viscosidade fornecendo o ciclometicone com uma viscosidade extremamente alta. A viscosidade do ciclometicone é aumentada através de um elastômero que fornece um "efeito suave", atributo próprio dos elastômeros. É uma mistura de elastômero de silicone de alto peso molecular (dimeticone crosspolymer) em ciclometicone.

a) INCI: Cyclopentasiloxane 
b) Aspecto ( $\left.\mathrm{T}=25^{\circ} \mathrm{C}\right)$ : líquido incolor;

c) Odor: característico;

d) Índice de Refração ( $\left.T=25^{\circ} \mathrm{C}\right):$ 1,397.

III. Crodamol GTCC foi adquirido da empresa Mapric apresentando grau de pureza farmacêutico. Os triglicérides do ácido cáprico e caprílico são triglicérides de cadeia média constituídos principalmente por ésteres de ácidos caprílicos (C8) e cápricos (C10) derivados do óleo de coco. Os TCM são derivados de ácidos graxos completamente saturados e por isso de baixa viscosidade. Esses óleos fluidos adquirem excepcional estabilidade oxidativa e oferecem ótimo espalhamento como resultado de sua característica saturada. Devido ao tamanho da cadeia, o Crodamol GTCC apresenta excelente solubilidade em álcool e daí sua importância na aplicabilidade em produtos farmacêuticos. Esses compostos são considerados toxicologicamente e dermatologicamente inócuos e são classificados como GRAS (Generally Recognized As Safe) pelo FDA. São excelentes solventes de princípios ativos devido à sua composição estrutural. É recomendado como substituto do óleo mineral, usado como veículo ou diluente, por ser também inerte. Compatível com óleos mineral e vegetal, ésteres sintéticos, silicones de baixa viscosidade e etanol.

a) INCI Name: Caprylic/Capric Triglyceride

b) Concentração usual: 1,0 a 10,0\%.

c) Aspecto $\left(25^{\circ} \mathrm{C}\right)$ : líquido incolor.

IV. Óleo de Castanha do Brasil foi adquirido da empresa Inovam do Brasil. É um óleo natural, emoliente, nutritivo e formador de filme. O óleo é rico em ácidos graxos insaturados (oléico e linoléico), fitoesteróis (sistosterol), além de esqualeno (nutrientes essenciais nos processos bioquímicos de formação do tecido epitelial). Rico em vitaminas lipossolúveis ( $\mathrm{A}$ e E) e oligoelementos ( $\mathrm{Ca}, \mathrm{Fe}, \mathrm{Zn}, \mathrm{Na}, \mathrm{K}$ e $\mathrm{Se}$ ). As especificações físico-químicas do Óleo de Castanha do Brasil segundo certificado de análise fornecido pela Inovam do Brasil são as seguintes:
a) INCI: Bertholletia excelsa Seed Oil
b) Prensado a frio (extra virgem) e filtrado.
c) Cor: amarelo claro.
d) Odor: suave, característico.
e) Densidade (25 $\stackrel{\circ}{\circ}): 0,900-0,930$. 
f) Índice de peróxido (meq $\mathrm{O}_{2} / \mathrm{Kg}$ ): Max. 13,0.

g) Índice de lodo ( $\left.\mathrm{gl}_{2} / 100 \mathrm{~g}\right): 90-120$.

h) Índice de Saponificação (mg KOH/g): 160 - 215.

i) Índice de Refração (40C): 1,4695.

\subsubsection{Antioxidante}

O BHT Cristal foi adquirido da empresa Mapric apresentando grau de pureza farmacêutico. É um antioxidante não clássico que auxilia na estabilização da vitamina $A$ e E, de óleos, gorduras, ceras e de carotenóides e é muito estável durante a estocagem por não reagir diretamente com o oxigênio gasoso. As especificações físico-químicas do BHT Cristal segundo certificado de análise fornecido pela Mapric são as seguintes:

a) INCI: BHT (Butyl Hydroxytoluene);

b) Aspecto: cristais.

c) Cor: branca.

d) Pureza: $99,20 \%$.

Tabela 6: Matérias-primas utilizadas na obtenção da formulação

\begin{tabular}{|c|c|c|c|}
\hline Fase & Componentes & Nome comercial & $\begin{array}{c}\text { Concentração } \\
(\%)\end{array}$ \\
\hline \multirow{4}{*}{$\begin{array}{l}\text { Љ } \\
\stackrel{0}{0} \\
\frac{0}{2}\end{array}$} & Água destilada & & 81,8 \\
\hline & Edetato dissódico & EDTA & 0,1 \\
\hline & Propano-1,2,3-triol & Glicerina & 3,0 \\
\hline & Fenoxietanol e parabenos & Phenova & 0,5 \\
\hline \multirow{7}{*}{ 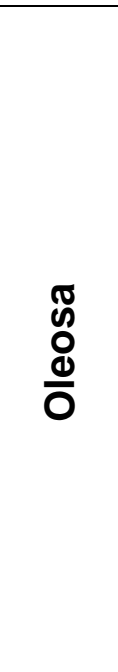 } & $\begin{array}{l}\text { Triglicerídeos de ácido } \\
\text { Cáprico/caprílico }\end{array}$ & Crodamol GTCC & 1,5 \\
\hline & $\begin{array}{l}\text { Alcool cetilico etoxilado e } \\
\text { propoxilado }\end{array}$ & Procetyl AWS & 0,5 \\
\hline & $\begin{array}{l}\text { Poliacrilamida } \quad \text { e } \\
\text { Isoparafina e Laurete } 7\end{array}$ & Sepigel ${ }^{\circledR} 305$ & 2,0 \\
\hline & Butilhidroxitolueno & $\mathrm{BHT}$ & 0,1 \\
\hline & Ciclometicone & Silicone DC ${ }^{\circledR} 1411$ & 3,0 \\
\hline & $\begin{array}{l}\text { Decametilciclopentassiloxano, } \\
\text { Crospolímero de dimeticone }\end{array}$ & Silicone DC ${ }^{\circledR} 9040$ & 2,5 \\
\hline & Óleo de Castanha do Brasil & & 5,0 \\
\hline
\end{tabular}




\subsubsection{Amostras}

Algumas formulações cosméticas na forma de emulsão foram desenvolvidas e os testes preliminares de estabilidade foram realizados para ajustar a concentração do tensoativo, obtendo, assim, a formulação cosmética sem a incorporação do óleo de Castanha do Brasil (F1A) e com a incorporação deste óleo (F2A).

Amostra comercial adquirida (creme hidratante).

4.1.3. Solventes, soluções e reagentes:

- Metanol grau analítico (99,8\%), marca $\operatorname{Merck}^{\circledR}$ (Darmstadt, Alemanha)

- Acetonitrila grau cromatográfico (99,9\%), marca Merck ${ }^{\circledR}$ (Darmstadt, Alemanha)

- Tetrahidrofurano grau analítico (99,8\%), marca Merck ${ }^{\circledR}$ (Darmstadt, Alemanha)

- Isopropanol grau analítico (99,8\%), marca Merck ${ }^{\circledR}$ (Darmstadt, Alemanha)

- Clorofórmio grau analítico (99,8\%), marca Merck ${ }^{\circledR}$ (Darmstadt, Alemanha)

- $\quad$-hexano grau analítico (99,8\%), marca Merck ${ }^{\circledR}$ (Darmstadt, Alemanha)

- Butanol grau analítico (99,8\%), marca Merck ${ }^{\circledR}$ (Darmstadt, Alemanha)

- Água MilliQ Plus ${ }^{\circledR}$

- Solução de $\mathrm{NaOH}$ 0,5 M em metanol

- $\mathrm{NaOH}$

- $\mathrm{BF}_{3} 14 \%$

- Heptano

- $\mathrm{NaCl}$

- Água destilada

- Solução de ácido clorídrico $1 \mathrm{M}$

- Solução de Folch (clorofórmio/metanol/água - 3:48:47)

- Brometil metoxi coumarina (BrMMC)

- 18-coroa-6-éter

- Carbonato de potássio

- Tetraborato de sódio 
- Imidazol

- Quinina

- Benzeno

- SDBS

- Fenol

- Histidina

4.1.4. Substâncias químicas empregadas como referência de grau cromatográfico

- Mistura padrão dos ésteres metílicos de ácidos graxos (F.A.M.E. Mix, C8-C22 Unsaturates): araquídico, behenóico, cis-13-docosenóico, docosaexaenóico, cis-11eicosapentaenóico, heptadecenóico, linoléico, linolênico, mirístico, miristicoléico, oléico, palmítico, palmitoléico, esteárico, obtidos da Sigma Chemical.

- Ácidos graxos (grau cromatográfico 99\%, obtidos de Sigma Chemical Co., St Louis, MO, USA): Palmítico, Margárico, Esteárico, Oléico, Linoléico, Linolênico, Capróico, Caprílico, Cáprico, láurico, mirístico, eicosapentaenóico (EPA), docosaexaenóico (DHA), araquidônico e palmitoléico.

\subsubsection{Consumíveis}

- Ponteiras, seringas e eppendorfs.

- Membrana filtrante de celulose regenerada, $25 \mathrm{~mm}$ de diâmetro e porosidade $0,45 \mu \mathrm{m}$ para fase móvel e para amostra membrana PTFE modificada 0,45 $\mu \mathrm{m}$ e 13 mm de diâmetro; ambas não estéreis (MILLIPORE).

- Capilares de sílica fundida de $75 \mu \mathrm{m}$ de diâmetro interno $(62,0 \mathrm{~cm}$ total e 50.2 $\mathrm{cm}$ efetivos) revestidos com poliimida Polymicro.

\subsubsection{Equipamentos}

- Agitador mecânico digital - $60 \mathrm{~Hz} / 87 \mathrm{~W}$

- Balança eletrônica decimal $5000 \mathrm{~g}$ divisão $0,1 \mathrm{~g}-60 \mathrm{~Hz} / \mathrm{VA} 7,5$

- Centrífuga Heraeus intruments modelo Megafuge 2.0

- Estufa de secagem 
- pHmetro marca Digimed DM 21

- Viscosímetro digital Brookfield LV modelo DV II + Pro

- Geladeira

- Fogão elétrico, 2 bocas, marca Roa, $220 \mathrm{~V}$

- Termômetro químico escala externa mercúrio $-10+110$, marca Incoterm

- Analisador termogravimétrico modelo TGA-51 marca Shimadzu

- Célula DSC, modelo 50 marca Shimadzu

- Cromatógrafo à gás modelo CG 17 A marca Shimadzu/Class CG 10, com detector de ionização de chama

- Cromatógrafo à líquido, detector de fluorescência (modelo RF-535), autoinjetor (modelo SIL-10ADvp) RF-10 AxL, bomba solvent delivery modelo LC10ADVP auto-injetor SIL-10DVP, todos da marca Shimadzu;

- Aparelho de eletroforese capilar PACE/MDQ (Beckman Instruments, Fullerton, CA, USA), equipado com um sistema de detecção por arranjo de diodos (DAD)

- Coluna analítica de fase reversa: Shim-pack CLC-C $84,6 \mathrm{~mm}$ i.d. x $25 \mathrm{~cm}$ com partículas de $5 \mu \mathrm{m}$, precedidas de pré-coluna (Shim-pack G-ODS 8,0 mm i.d.x 1,5 $\mathrm{cm})$

- Capilar de sílica fundida Polymicro (75 $\mu \mathrm{m}$ d.i., $62,0 \mathrm{~cm}$ de comprimento total (50,2 cm até o detector)

\subsection{MÉTODOS}

\subsubsection{Caracterização da matéria-prima}

A primeira etapa do presente trabalho consistiu na caracterização do óleo de Castanha do Brasil em sua composição de ácidos graxos e para isso esse óleo foi submetido a análises para identificação dos ácidos graxos presentes em sua composição. Os métodos de cromatografia em fase gasosa e cromatografia em fase líquida de alta eficiência foram escolhidos para esse fim, porém trata-se de metodologias já bastante utilizadas. 


\subsubsection{Cromatografia em fase gasosa (CG)}

\subsection{Preparo da solução de ácidos graxos}

Para análise dos ácidos graxos presentes no óleo de Castanha do Brasil, realizou-se primeiramente um processo de transesterificação dos ácidos graxos presentes na composição do óleo sob a forma de triglicerídeos e em seguida foi realizada a esterificação destes ácidos livres. Os ésteres metílicos de ácidos graxos foram preparados de acordo com o método oficial American Oil Chemists' Society AOCS Ce 2-66 (1998) procedeu-se da seguinte maneira:

Pesou-se cerca de 0,068-0,0798 mg de óleo em tubos de ensaio em uma balança analítica. Em seguida adicionou-se ao óleo, $2 \mathrm{~mL}$ de $\mathrm{NaOH}$ 0,5M em metanol e agitou-se. Os tubos foram colocados em banho fervente por 10 minutos. Logo após esse período, foram adicionados $2,5 \mathrm{~mL}$ de $\mathrm{BF}_{3} 14 \%$ e os tubos foram novamente colocados em um banho fervente por mais 2 minutos. Adicionou-se 1 $\mathrm{mL}$ de heptano e os tubos foram agitados e levados ao banho novamente por mais 1 minuto. Após serem removidos do aquecimento, foram adicionados $5 \mathrm{~mL}$ de solução saturada de $\mathrm{NaCl}$. Os frascos foram tampados e agitados vigorosamente por 15s, enquanto a solução ainda permanecia morna. Foram extraídos $2 \mathrm{~mL}$ de solução e os extratos foram transferidos para os vials contendo aproximadamente $0,5 \mathrm{~g}$ de $\mathrm{Na}_{2} \mathrm{SO}_{4}$ anidro P.A. As análises foram realizadas em triplicata.

\subsection{Condições empregadas no ensaio}

- Coluna capilar de sílica fundida Supelcowax 10 de $30 \mathrm{~m}$ e 0,25 mm de d.i.

- Temperatura programada da coluna: razão de aquecimento a $1^{\circ} \mathrm{C} / \mathrm{min}$ de 170 até $225^{\circ} \mathrm{C}$, permanecendo nesta temperatura por 10 mi nutos;

- Temperatura do vaporizador: $250^{\circ} \mathrm{C}$.

- Temperatura do detetor: $270^{\circ} \mathrm{C}$

- Gás de arraste: Hélio

- Velocidade linear do gás de arraste: $1 \mathrm{~mL} / \mathrm{min}$

- Razão de divisão da amostra: 1:50 
Para a identificação dos ácidos graxos foram utilizados padrões de ésteres metílicos de ácidos graxos puros, comparando-se o tempo de retenção dos ésteres metílicos das amostras e dos padrões. A identificação e quantificação preliminar dos ácidos graxos foram realizadas por normalização de área, expressando-se o resultado em percentual de cada ácido sobre o total de ácidos graxos.

\subsubsection{Cromatografia em fase líquida de alta eficiência (CLAE)}

\subsection{Preparo da solução de ácidos graxos padrões}

Para padronização da metodologia de separação, foram utilizados os seguintes padrões de ácidos graxos: capróico, caprílico, cáprico, láurico, mirístico, palmítico, esterárico, oléico, linoléico, linolênico, margárico, eicosapentaenóico (EPA), docosaexaenóico (DHA), araquidônico e palmitoléico, obtidos de Sigma Chemical Co., St Louis, MO, USA.

Os solventes utilizados como fase móvel foram: acetonitrila (ACN) adquirido da Merck, Deutschland (HPLC grade) e a água ultrapura. Todos os padrões foram solubilizados em acetonitrila.

4.2.1.2.2. Extração dos ácidos graxos no óleo de Castanha do Brasil para análise em cromatografia em fase líquida de alta eficiência

Uma amostra do óleo de Castanha do Brasil foi colocada em microtubos de 2 $\mathrm{mL}$ e adicionou-se $450 \mu \mathrm{L}$ de metanol e homogeneizou-se por 15 segundos no vórtex. Logo após adicionou-se, $950 \mu \mathrm{L}$ de $\mathrm{HCCl}_{3}$ e homogeneizou-se por mais 15 segundos no vórtex. Centrifugou-se até a separação de fases. Formando-se uma solução bifásica, a fase superior (hidrofílica) passou por mais duas extrações adicionando-se mais $500 \mu \mathrm{l}$ de metanol, $500 \mu \mathrm{l}$ de clorofórmio e $400 \mathrm{UI}$ de água e homogeneizou-se no vórtex. Centrifugou-se novamente para separar as fases. Os extratos clorofórmicos resultantes receberam $350 \mu \mathrm{L}$ de solução de Folch $(\mathrm{FOLCH}$, 1957) (3 clorofórmio/ 48 metanol/ 47 água $-\mathrm{v} / \mathrm{v} / \mathrm{v}$ ) e foram agitados em vórtex e centrifugados rapidamente para melhor separação das fases. A fase superior foi descartada, e a fase orgânica evaporada através de fluxo de nitrogênio. 
4.2.1.2.3. Saponificação de ácidos graxos para análise em cromatografia em fase líquida de alta eficiência

Transferiu-se as amostras extraídas em tubos de $10 \mathrm{~mL}$, ressuspendendo os ácidos graxos com $2 \mathrm{~mL}$ de $\mathrm{NaOH}$ 0,5 M em metanol 90\% para promover a hidrólise alcalina. Vedou-se os tubos com parafilm e deixou-os em banho-maria à $37^{\circ} \mathrm{C}$ e 150 rpm durante 2 horas. Após esse período os tubos foram resfriados e a solução foi neutralizada com $2 \mathrm{~mL}$ de $\mathrm{HCl} 1 \mathrm{M}$. Em seguida foram adicionados $1 \mathrm{~mL}$ de hexano para extração dos ácidos graxos. A extração é repetida e novamente o extrato lipídico é obtido após secagem com nitrogênio.

4.2.1.2.4. Derivatização com bromometil-metóxi-coumarina (BrMMC) para a formação de um complexo fluorescente

Duas soluções foram preparadas separadamente. A primeira (solução A) foi feita com $10 \mathrm{mg}$ de BrMMC dissolvidos em $10 \mathrm{~mL}$ de acetonitrila num frasco âmbar. $\mathrm{Na}$ solução B adicionou-se $26,5 \mathrm{mg}$ de 18 -crown-6 e $100 \mathrm{mg}$ de carbonato de potássio dissolvidos em $5 \mathrm{~mL}$ de acetonitrila, a qual foi sonicada por 30 minutos e foram adicionados mais $5 \mathrm{~mL}$ de acetonitrila. $O$ sobrenadante foi utilizado. As amostras lipídicas que passaram pela saponificação foram restituídas com $100 \mu \mathrm{L}$ de acetonitrila e homogeneizadas no vórtex. Adicionou-se no vial $40 \mu \mathrm{L}$ desta solução, $20 \mu \mathrm{L}$ da solução $\mathrm{A}$ e $20 \mu \mathrm{L}$ da solução $\mathrm{B}$ e homogeneizou-se no vórtex. Após as amostras serem incubadas à $60^{\circ} \mathrm{C}$ em banho seco por 15 minutos, os vials foram resfriados à temperatura ambiente e mantidos a $1^{\circ} \mathrm{C}$ até $\mathrm{o}$ momento da injeção no equipamento.

A concentração de cada ácido graxo foi calculada pela divisão da área de cada pico pela área total dos picos.

\subsection{Condições empregadas no ensaio}

- O equipamento utilizado possui um sistema com duas bombas (modelo LC-10ADvp), auto-injetor (modelo SIL-10ADvp) e detector de fluorescência (modelo RF-535). As colunas analíticas utilizadas possuem as determinadas características: 
coluna C-8, de fase reversa, com $25 \mathrm{~cm} \times 4,6 \mathrm{~mm} \times 5 \mu \mathrm{m}$ (comprimento $\times$ diâmetro interno $x$ diâmetro das partículas) precedidas de pré-coluna (Shim-pack G-ODS 8,0 $\mathrm{mm}$ i.d.x $1,5 \mathrm{~cm})$.

- O programa para integração e registro de dados deste sistema é o Class LC-10, versão 1.4 (marca Shimadzu) (RILEY, 1999).

A curva de calibração para cada padrão com injeções de volumes crescentes de cada ácido graxo até a obtenção das curvas.

A estratégia utilizada para a separação foi um sistema isocrático com $23 \%$ de água e $73 \%$ de ACN com fluxo de $0,5 \mathrm{~mL} / \mathrm{min}$. A duração da corrida foi de 120 minutos e a partir do cromatograma resultante foram realizados gradientes de eluição e variações no fluxo visando a uma melhor separação com boa resolução e menor tempo de corrida. No teste de vários gradientes foi observada a sobreposição de alguns picos, apesar de uma melhora na resolução. Porém, com alguns ajustes foi possível reduzir o tempo de corrida para 60 minutos com uma separação bem definida e uma boa resolução dos ácidos graxos. Os compostos foram detectados fluorimetricamente, com excitação a 325 nm e emissão a 398 nm.

\subsubsection{Eletroforese capilar (EC)}

A segunda etapa do trabalho foi o desenvolvimento do método analítico por eletroforese capilar para identificação dos ácidos graxos presentes em maior proporção no óleo de Castanha do Brasil em formulações cosméticas, segundo as determinações realizadas neste trabalho e relatos na literatura.

\subsection{Desenvolvimento analítico}

Para definição dos parâmetros foram realizados estudos do comportamento eletroforético de seis ácidos graxos em associação equimolecular, os quais se podem citar: ácidos palmítico, esteárico, margárico (padrão interno), oléico, linoléico e linolênico. Os parâmetros avaliados durante os ensaios foram a diferença de potencial, o tempo de injeção, a pressão de injeção da amostra, o tempo de corrida, o pH, a natureza e concentração do eletrólito e a concentração dos ácidos graxos. 


\subsection{Preparo do eletrólito}

O tampão de tetraborato de sódio era preparado semanalmente como uma solução estoque de concentração $100 \mathrm{mmol} / \mathrm{L}$ e a partir dela, uma nova solução de trabalho, na concentração testada, era preparada a cada dia.

No desenvolvimento do método de eletroforese capilar foram preparadas as seguintes soluções estoque:

(a) Tampão tetraborato $100 \mathrm{mmol} / \mathrm{L}$ : foram pesados 1,91 $\mathrm{g}$ de tetraborato de sódio e dissolvidos em um balão volumétrico de $50 \mathrm{~mL}$ com água ultra-pura e colocado sob agitação por 10 minutos no ultrasson. O ajuste necessário do pH da solução de tampão tetraborato foi realizado utilizando $\mathrm{HCl} 0,1 \mathrm{~N}$.

(b) SDBS: foram pesados $0,87 \mathrm{~g}$ e dissolvidos em um balão de $50 \mathrm{~mL}$ com água ultra-pura, este volume foi transferido para um balão volumétrico de $50 \mathrm{~mL}$ e agitado em ultrasson e o volume ajustado com água ultra-pura.

(c) $\mathrm{Brij}^{\circledR}$ 35: foram pesados $1,498 \mathrm{~g}$ e dissolvidos em aproximadamente $20 \mathrm{~mL}$ de água ultra-pura, este volume foi transferido para um balão volumétrico de $25 \mathrm{~mL}$ e agitado em ultrasson e o volume ajustado com água ultra-pura.

\subsection{Soluções dos ácidos graxos}

As soluções estoque dos ácidos graxos palmítico, margárico, esteárico, oléico, linoléico e linolênico foram preparadas diariamente a uma concentração final de $2000 \mathrm{mg} / \mathrm{mL}$ e mantidas em refrigerador até o momento de uso. As soluções de trabalho foram preparadas a partir destas soluções à temperatura ambiente.

Na preparação da solução estoque de ácidos graxos foram pesados $20 \mathrm{mg}$ de cada ácido e transferidos para balões volumétricos de $10 \mathrm{~mL}$ e dissolvidos em metanol. Após confirmação da completa dissolução em ultrasson os mesmos foram levados a volume final com metanol. 


\subsection{Definição dos parâmetros eletroforéticos}

Para definição dos parâmetros foram realizados estudos do comportamento eletroforético dos seis ácidos graxos em associação equimolar. Os parâmetros avaliados durante os ensaios foram: diferença de potencial, tempo de corrida, $\mathrm{pH}$, natureza e concentração do eletrólito, tempo de injeção, concentração dos ácidos graxos. O comprimento de onda escolhido foi o de $224 \mathrm{~nm}$, uma vez que o cromóforo utilizado (SDBS) absorve a esse valor de absorbância (OLIVEIRA et al, 2004).

\subsection{Condições do equipamento}

Um equipamento de eletroforese capilar PACE/MDQ (Beckman Instruments, Fullerton, CA, USA), equipado com um sistema de detecção por arranjo de diodos (DAD) e um software para o tratamento e aquisição de dados (32 Karat TM). As amostras foram introduzidas no capilar por injeção hidrodinâmica aplicando 0,3psi/3s (1 psi $=6894,76 \mathrm{~Pa}$ ). O instrumento foi operado sob polaridade positiva.

O condicionamento do capilar foi utilizado em capilar de sílica fundida com 75 $\mu \mathrm{m}$ de diâmetro interno (d.i.) e um comprimento total de $62,0 \mathrm{~cm}(50,2 \mathrm{~cm}$ até o detector). A temperatura do capilar foi mantida a $25^{\circ} \mathrm{C}$. Ao iniciar as medidas, o capilar foi acondicionado com a solução de $\mathrm{NaOH} 0,1 \mathrm{~mol} \mathrm{~L}^{-1}$ por 15 minutos, água deionizada por 15 minutos e com o eletrólito por 15 minutos. Entre corridas o capilar foi lavado com solução de metanol por 3,5 minutos, $\mathrm{NaOH} 0,1 \mathrm{~mol} \mathrm{~L}^{-1}$ por $1,5 \mathrm{~min}$ e com água deionizada por 1,5 minutos. Ao final do dia o capilar foi lavado com a solução de $\mathrm{NaOH}$ 0,1M por 20 min e 20 min com água deionizada. O metanol foi adicionado nas lavagens entre corridas uma vez que se observou, no decorrer do desenvolvimento do método em questão. A importância deste solvente foi evitar problemas como entupimentos de capilares e queda de corrente.

\subsection{Parâmetros experimentais otimizados}

Método de detecção por arranjo de diodos

Tensão aplicada: + 20 kV; 
Tempo de injeção: 3seg/0,3 psi;

Temperatura: $25^{\circ} \mathrm{C}$;

Capilar: $75 \mu \mathrm{m}$ d.i., $62,0 \mathrm{~cm}$ de comprimento total $(50,2 \mathrm{~cm}$ até o detector);

Polaridade: positiva;

Comprimento de onda: $224 \mathrm{~nm}$.

\subsection{Preparação da formulação cosmética desenvolvida}

As formulações desenvolvidas foram denominadas e codificadas como: Formulação cosmética sem a presença do óleo de Castanha do Brasil (F1A) e formulação cosmética com a incorporação do óleo de Castanha do Brasil (F2A).

Os componentes da fase aquosa foram misturados à frio, com exceção do EDTA, que foi dissolvido em pequena quantidade de água destilada até a temperatura de $70^{\circ} \mathrm{C}$, e esta quantidade de água foi descontada da quantidade total de água do sistema.

O butil-hidroxi-tolueno $(\mathrm{BHT})$ foi dissolvido à quente até a temperatura de $7^{\circ} \mathrm{C}$ ao triglicérides do ácido cáprico/caprílico. E stes foram adicionados ao palmitato de octila, Procetyl AWS e ao óleo de Castanha do Brasil. Verteu-se a fase oleosa na fase aquosa à frio sob agitação e adicionou-se o Sepigel 305 , e por último adicionaram-se os ciclometicone e dimeticone.

4.4. Preparação das amostras das formulações cosméticas para análise em Eletroforese capilar

\subsubsection{Extração da fase oleosa das amostras das formulações desenvolvidas}

Lipídios totais das amostras das formulações cosméticas foram determinados pelo método descrito por BLIGH \& DYER (1959), empregando-se os solventes clorofórmio, metanol e água (proporção 1:2:0.8 v/v/v) para extração dos lipídios.

\subsubsection{Saponificação da fase oleosa extraída das formulações desenvolvidas}

O volume total de fase oleosa obtido da extração das formulações foi saponificado segundo método de Hartman \& Lago (1973). O sistema consistiu de um 
banho de aquecimento com água destilada onde um balão de fundo redondo de 25 $\mathrm{mL}$ foi conectado a um tubo cilíndrico de vidro utilizado com condensador. O esquema está mostrado na Figura 10. As amostras contidas dentro dos balões foram adicionadas à $5 \mathrm{~mL}$ de $\mathrm{NaOH} 0,5 \mathrm{~mol} / \mathrm{L}$ em metanol. Os balões foram colocados sob refluxo, em banho-maria à temperatura de $75-80^{\circ} \mathrm{C}$ por 25 minutos. Após esse período as amostras foram retiradas do banho e resfriadas em sistema de gelo seco. Alíquotas saponificadas do óleo foram diluídas 50 vezes em metanol antes da injeção no equipamento de eletroforese capilar.

\subsubsection{Saponificação das matérias-primas}

As matérias-primas utilizadas na preparação da formulação desenvolvida foram saponificadas para posterior análise em Eletroforese capilar com o objetivo de verificar a interferência ou não na identificação dos ácidos graxos do óleo de Castanha do Brasil. Todas as matérias-primas foram inicialmente pesadas proporcionalmente a sua composição na formulação cosmética desenvolvida e saponificadas segundo método de Hartman \& Lago (1973).

As matérias-primas foram pesadas dentro de balões de fundo redondo de 25

$\mathrm{mL}$ e levados ao banho de aquecimento com água destilada. Os balões foram conectados a tubos cilíndricos de vidro utilizados com condensador (figura 10). As amostras contidas dentro dos balões foram adicionadas à $1 \mathrm{~mL}$ de $\mathrm{NaOH} 0,5 \mathrm{~mol} / \mathrm{L}$ em metanol. Os balões foram colocados sob refluxo, em banho-maria à temperatura de $75-80^{\circ} \mathrm{C}$ por 25 minutos. Após esse período as amo stras foram retiradas do banho e resfriadas em sistema de gelo seco. Alíquotas saponificadas das matériasprimas foram diluídas 50 vezes em metanol antes da injeção no equipamento de eletroforese capilar (OLIVEIRA, 2003).

\subsection{Saponificação do óleo de Castanha do Brasil}

Amostras do óleo de Castanha do Brasil in natura foram saponificadas segundo método de Hartman \& Lago, descrito no item anterior (HARTMAN \& LAGO, 1973). Foram pesadas amostras de $100 \mathrm{mg}$ de óleo de Castanha do Brasil (correspondente a $5 \% \mathrm{em} 2 \mathrm{~g}$ da formulação que foi submetida à extração) em balão de $25 \mathrm{~mL}$ de fundo redondo e adicionado $5 \mathrm{~mL}$ de $\mathrm{NaOH} 0,5 \mathrm{~mol} / \mathrm{L}$ em metanol. 
Esse balão foi colocado sob refluxo, em banho maria à temperatura de $75-80^{\circ} \mathrm{C}$ por 25 minutos. Após esse período as amostras foram retiradas do banho e resfriadas em sistema de gelo seco. Alíquotas saponificadas foram diluídas 50 vezes em metanol antes da injeção no equipamento de eletroforese capilar. É válido salientar que o tempo de reação para a saponificação de 25 minutos foi escolhido para o presente trabalho devido a um estudo realizado por Oliveira onde verificou que o tempo ótimo de reação para saponificação total do conteúdo graxo situa-se entre 25 e 30 minutos, sendo que acima deste tempo os valores de área pico/massa apresentam relevante declínio (OLIVEIRA, 2003).

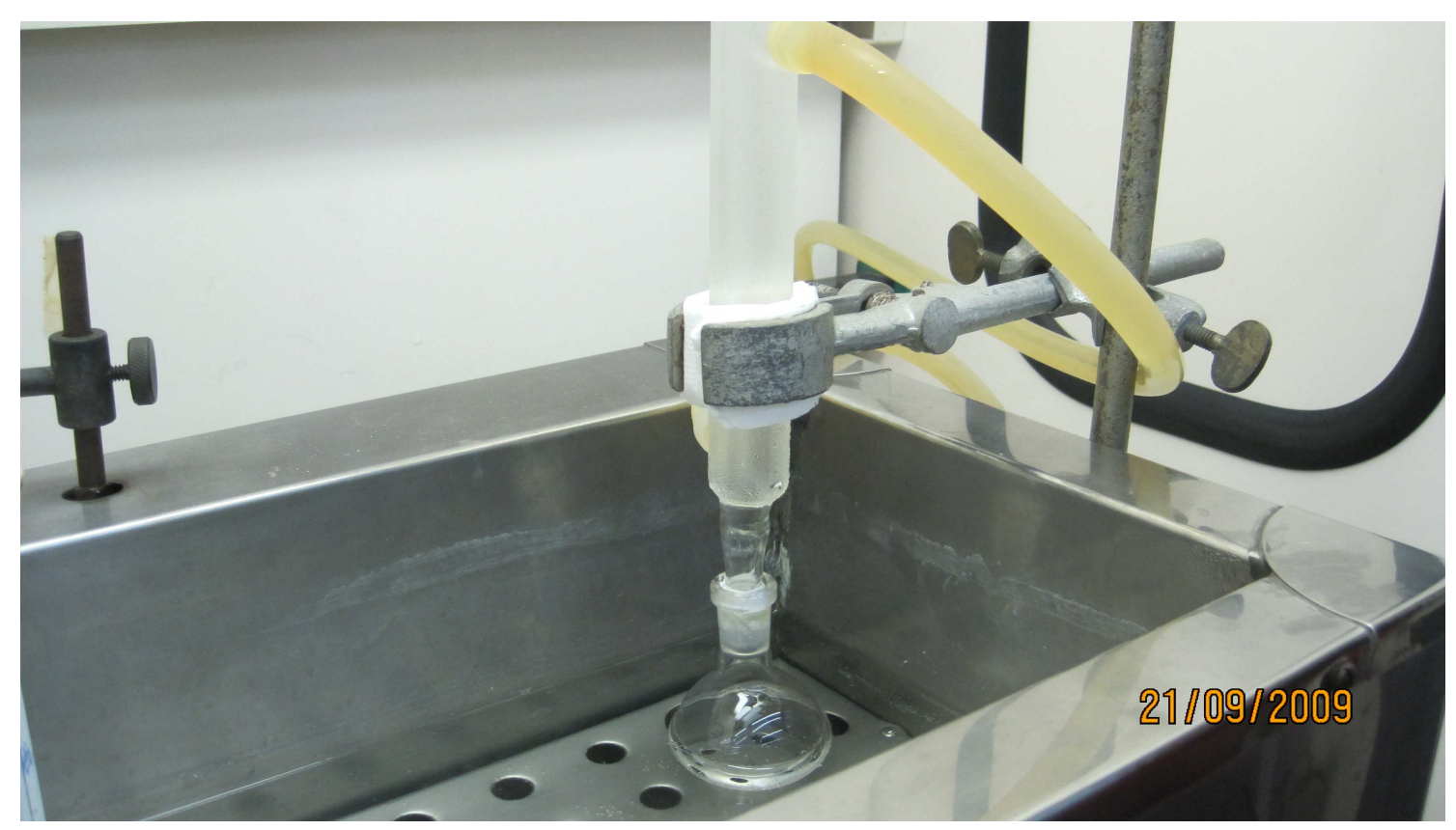

Figura 10: llustração fotográfica do sistema utilizado para as reações de saponificação das amostras.

4.6. Estudo de estabilidade das formulações cosméticas

\subsubsection{Teste de centrifugação}

Foram pesadas alíquotas de 5,0 gramas das formulações e acondicionadas em tubo graduado para centrífuga. As amostras foram centrifugadas (Centrífuga Heraeus intruments modelo Megafuge 2.0), em ciclos de 30 minutos na velocidade de $3000 \mathrm{rpm}$ à temperatura de $25^{\circ} \mathrm{C}$ antes de iniciar os Estudos de Estabilidade. 
4.6.2. Teste de estabilidade acelerada

Foram obtidas 1000 gramas de cada fórmula, divididas nas seguintes embalagens de vidro com tampas de plástico e formas de armazenamento (BRASIL, 2004):

Embalagem de vidro incolor:

- Estufa à temperatura controlada de 45으. $\mathrm{C}$.

- Geladeira à $5 \stackrel{\circ}{\circ}$.

- $\quad$ Ambiente à $25^{\circ} \mathrm{C}$.

- $\quad$ Exposição à radiação solar.

- Ciclos de congelamento e descongelamento de 24 horas à $45 \pm 2^{\circ} \mathrm{C}$, e 24 horas $a-5 \pm 2^{\circ} \mathrm{C}$.

Durante 0 envase não foi completado o volume total da embalagem permitindo um espaço vazio (headspace) de aproximadamente um terço da capacidade do frasco para possíveis trocas gasosas.

\subsubsection{Avaliação das formulações cosméticas}

As avaliações foram realizadas nos tempos: zero (T0); um (T1); sete (T7); quinze (T15); trinta (T30); sessenta (T60) e noventa (T90) quanto ao aspecto, cor, odor, $\mathrm{pH}$ e viscosidade aparente (BRASIL, 2004). Os resultados foram compilados sob a forma de tabela.

É válido relatar que, para análise de $\mathrm{pH}$, pesou-se $1 \mathrm{~g}$ de cada formulação em tubo de ensaio, acrescentando-se $9 \mathrm{~mL}$ de água destilada. Após dispersão da mistura, o pH foi mensurado à temperatura ambiente.

Para a medida da viscosidade aparente utilizou-se viscosímetro rotativo, com sensor n34, à velocidade de 0,30 rpm e massa de am ostra de aproximadamente $15 \mathrm{~g}$. Para todas as amostras, as leituras foram efetuadas após 2 minutos de estabilização das preparações, a temperatura de 25,0 $\pm 2,0^{\circ} \mathrm{C}$. Para os testes de estabilidade preliminar e acelerada, a seguinte nomenclatura foi empregada para 
classificar as formulações quanto ao aspecto, cor e odor: $\mathbf{N}=$ Normal, sem alteração; $\mathbf{L} \mathbf{M}=$ Levemente Modificado; $\mathbf{M}=$ Modificado e $\mathbf{I M}=$ Intensamente Modificado.

\subsubsection{Determinação do tipo de emulsão}

Para avaliação do tipo de emulsão foi utilizado o teste de diluição (SANTOS et al, 2006) que consiste na determinação da solubilidade da fase externa da emulsão em dois solventes: água e óleo mineral (SANTOS et al., 2006). Para isso, pesou-se $1,0 \mathrm{~g}$ das formulações em um tubo de ensaio, adicionando em seguida 9,0 gramas do solvente. Homogeneizou-se com o auxílio de um vórtex, mantendo em repouso por 5 minutos após agitação. Empregou-se a seguinte classificação:

a) Emulsão $\mathrm{A} / \mathrm{O}=$ solúvel em óleo mineral, formação de fase homogênea e sem grumos;

b) Emulsão $O / A=$ solúvel em água, formação de fase homogênea e sem grumos.

\subsection{Análise térmica}

\subsubsection{Termogravimetria/Termogravimetria derivada (TG/DTG)}

O óleo de Castanha do Brasil, as formulações desenvolvidas e os ácidos graxos padrões isolados foram submetidos à análise termogravimétrica e as curvas TG/DTG termogravimétricas foram obtidas por um equipamento da marca Shimadzu, modelo TGA-51, nas seguintes condições experimentais: atmosfera dinâmica de ar (vazão de $50 \mathrm{~mL} / \mathrm{min}$ ), taxa de aquecimento de $10^{\circ} \mathrm{C} / \mathrm{m}$ in, faixa de temperatura de 25 a $900^{\circ} \mathrm{C}$ e cadinho de Pt contendo cerca de $5 \mathrm{mg}$ de amostra.

\subsubsection{Calorimetria Exploratória Diferencial (DSC)}

As curvas DSC das amostras de óleo de Castanha do Brasil isolado foram obtidas por uma célula DSC, modelo 50 da marca Shimadzu nas seguintes condições experimentais: razão de aquecimento de $10^{\circ} \mathrm{C} / \mathrm{min}$, faixa de temperatura de 25 a $500{ }^{\circ} \mathrm{C}$, sob atmosfera dinâmica de $\mathrm{N}_{2}(50 \mathrm{~mL} / \mathrm{min})$, cápsula de $\mathrm{Al}$ parcialmente fechada contendo aproximadamente $5 \mathrm{mg}$ de amostra. 
4.7.3. Estudo cinético do óleo de Castanha do Brasil por Termogravimetria

O óleo de Castanha do Brasil foi submetido a um estudo cinético por termogravimetria pelo método isotérmico. As curvas TG foram obtidas a partir do aquecimento das amostras até as temperaturas de $230,235,240,245$ e $250^{\circ} \mathrm{C}$, e mantidas em condições isotérmicas durante o tempo necessário para uma perda de massa superior a 5\%. O equipamento utilizado foi da marca Shimadzu, modelo TGA51, nas seguintes condições experimentais: atmosfera dinâmica de ar (vazão de 50 $\mathrm{mL} / \mathrm{min}$ ), cadinho de Pt contendo cerca de $20 \mathrm{mg}$ de amostra com razão de aquecimento inicial de $20^{\circ} \mathrm{C} / \mathrm{min}$ e final de $5^{\circ} \mathrm{C} / \mathrm{min}$. 


\section{RESULTADOS E DISCUSSÃO}

\subsection{Cromatografia}

5.1.1. Cromatografia em fase gasosa (CG)

A Figura 11 mostra o cromatograma de uma mistura padrão de ésteres metílicos utilizada para identificação dos ácidos graxos do óleo de Castanha do Brasil.

Nas condições descritas para o método de cromatografia em fase gasosa, o éster metílico do ácido palmítico (C16:0) foi o primeiro a ser identificado. Em seguida, o cromatograma revelou os ésteres metílicos dos ácidos esteárico (C18:0), oléico (C18:1), linoléico (C18:2), linolênico (C18:3) e por último o araquídico (C20:0) (Figura 12). Outros foram identificados e quantificados em menores concentrações, como os ácidos palmitoléico (C16:1) e mirístico (C14:0). Este resultado demonstra que o tamanho da cadeia dos ácidos graxos exerce maior influência na ordem de eluição do que o número de insaturações do composto, ou seja, quanto menor a cadeia menor o tempo de retenção no cromatógrafo.

A Tabela 7 fornece os tempos de retenção de cada um dos ésteres metílicos dos ácidos graxos que foram identificados, bem como seus percentuais (\%) contidos na amostra analisada medidos pela área do pico no cromatograma.

Tabela 7: Tempo de retenção e composição dos ácidos graxos do óleo de Castanha do Brasil identificados como ésteres metílicos dos ácidos graxos obtidos do cromatograma da Figura 12.

\begin{tabular}{l|c|c}
\hline \hline Éster metílico do ácido: & Tempo de retenção (min) & Concentração (\%) \\
\hline \hline 1- Palmítico & 8,72 & $14,51 \pm 0,04$ \\
2- Esteárico & 14,62 & $11,45 \pm 0,07$ \\
3- Oléico & 15,38 & $29,4 \pm 0,04$ \\
4- Linoléico & 17,22 & $42,82 \pm 0,06$ \\
5- Linolênico & 19,86 & $0,07 \pm 0,01$ \\
6- Araquídico & 23,21 & $0,26 \pm 0,00$ \\
\hline \hline
\end{tabular}




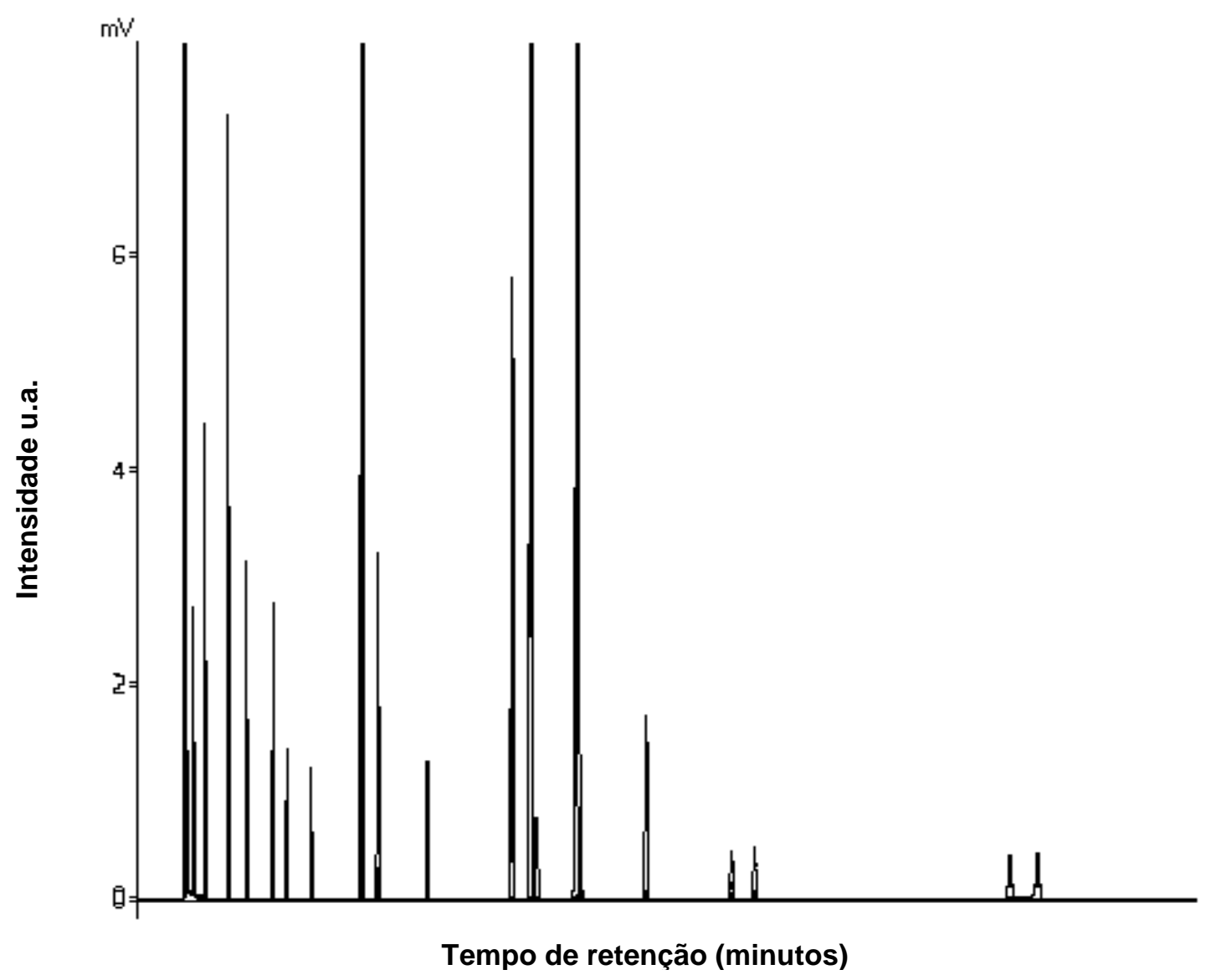

Figura 11: Cromatograma da mistura padrão de ésteres metílicos de ácidos graxos. Condições cromatográficas: Coluna de sílica fundida Supelcowax 10 de $30 \mathrm{~m}$ e 0,25 $\mathrm{mm}$ de d.i.; Temperatura programada da coluna: aquecimento a $1^{\circ} \mathrm{C} / \mathrm{min}$ de $170{ }^{\circ} \mathrm{C}$ até $225^{\circ} \mathrm{C}$, permanecendo nesta temperatura por 10 mi nutos; Temperatura do vaporizador: ${ }^{250}{ }^{\circ} \mathrm{C}$; Temperatura do detetor: $270^{\circ} \mathrm{C}$; Gás de arraste: Hélio; Detector de ionização de chama; Velocidade linear do gás de arraste: $1 \mathrm{~mL} / \mathrm{min}$; Razão de divisão da amostra: 1:50; equipamento cromatógrafo á gás CG 17 A Shimadzu/Class CG 10. 


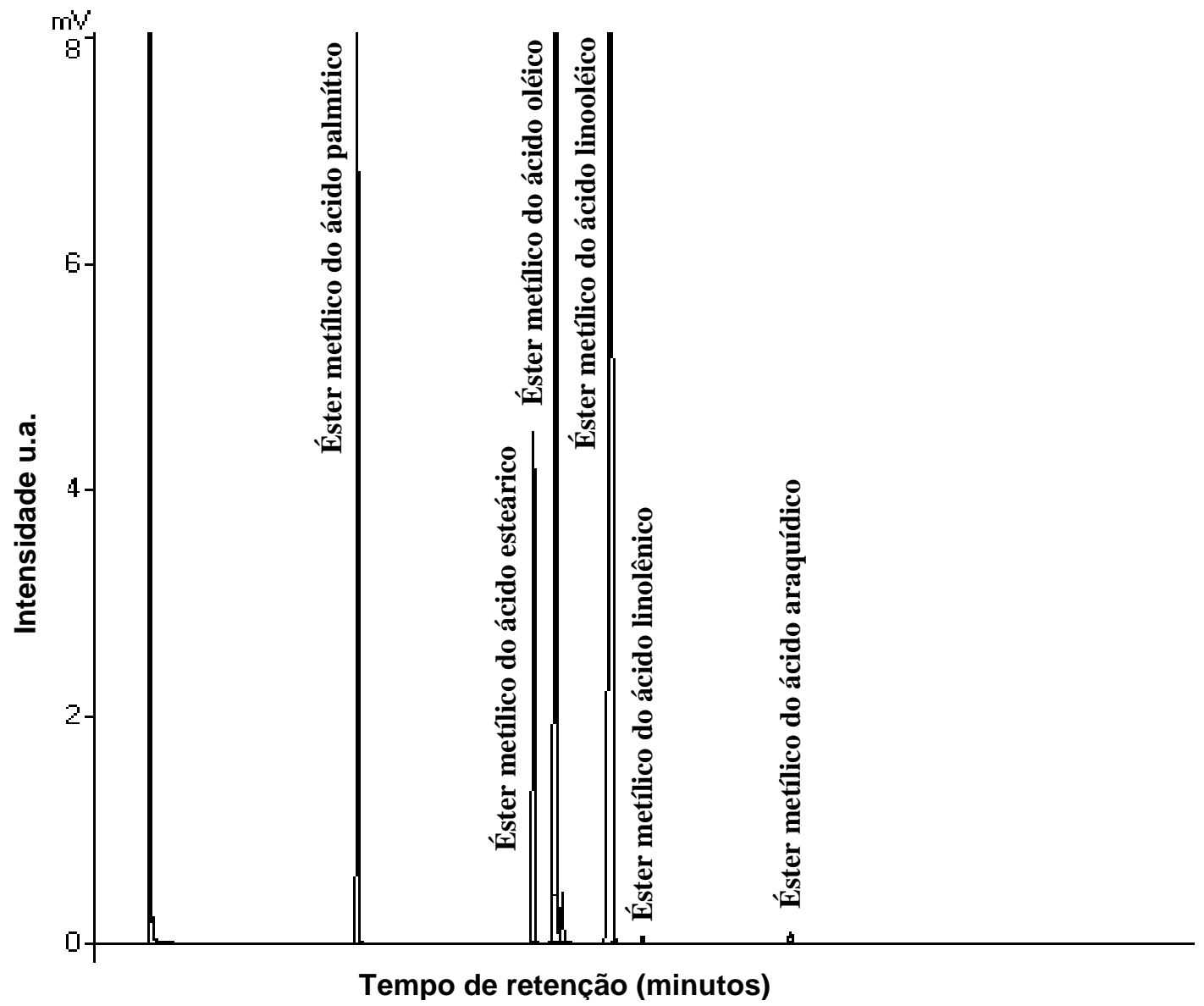

Figura 12: Cromatograma dos ésteres metílicos de ácidos graxos do óleo de Castanha do Brasil. Condições cromatográficas: Coluna de sílica fundida Supelcowax 10 de $30 \mathrm{~m}$ e $0,25 \mathrm{~mm}$ de d.i.; Temperatura programada da coluna: aquecimento a $1^{\circ} \mathrm{C} / \mathrm{min}$ de $170^{\circ} \mathrm{C}$ até $225^{\circ} \mathrm{C}$, permanec endo nesta temperatura por 10 minutos; Temperatura do vaporizador: $250{ }^{\circ} \mathrm{C}$; Temp eratura do detetor: $270{ }^{\circ} \mathrm{C}$; Gás de arraste: Hélio; Detector de ionização de chama; Velocidade linear do gás de arraste: $1 \mathrm{~mL} / \mathrm{min}$; Razão de divisão da amostra: 1:50; equipamento cromatógrafo á gás CG 17 A Shimadzu/Class CG 10.

A composição de ácidos graxos do óleo de Castanha do Brasil obtida por CG demonstrou uma insaturação elevada $(72,2 \%)$ no nível deste óleo, devido essencialmente aos ácidos oléico C18:1 (29,4\%) e linoléico C18:2 (42,82\%). Os resultados estão compilados na Tabela 1. Os valores aqui obtidos são muito próximos aos obtidos na literatura por: Venkatachalam e colaboradores $(28,75 \%$ de C18:1 e 45,43\% de C18:2) (VENKATACHALAM et al., 2006), Gutierrez e colaboradores (29,0\% de C18:1 e 48,8\% de C18:2) (GUTIERREZ et al., 1997), Elias \& Bressani $(30,5 \%$ de $C 18: 1$ e $44,9 \%$ de C18:2) (ELIAS \& BRESSANI, 1961) e Ryan e colaboradores $(29,09 \%$ de C18:1 e $42,8 \%$ de C18:2) (RYAN et al.,2006). 
Devido à alta insaturação dos ácidos graxos e ao elevado teor de ácido linoléico confere a esse óleo algumas propriedades interessantes para uma dieta saudável.

Por conter alto teor de ácido linoléico, que é um ácido graxo encontrado na pele humana e com propriedades emolientes, este óleo vem a viabilizar a aplicação cosmética do óleo de Castanha do Brasil em emulsões cosméticas.

\subsubsection{Cromatografia em fase líquida de alta eficiência (CLAE)}

A Figura 13 mostra o cromatograma obtido a partir de uma solução de 15 padrões de ácidos graxos. Estes padrões foram utilizados para a identificação e uma quantificação preliminar dos ácidos graxos presentes no óleo de Castanha do Brasil.

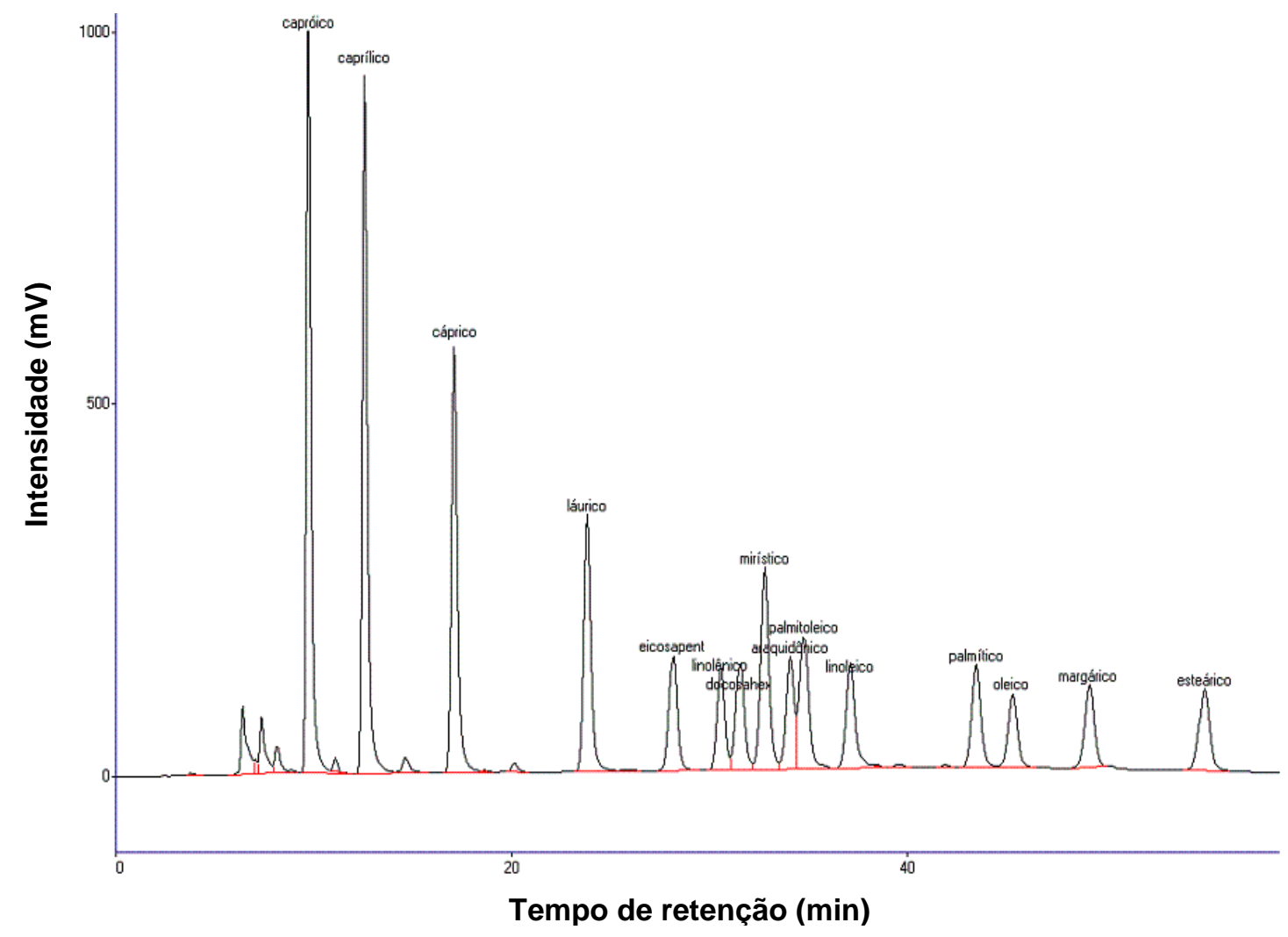

Figura 13: Cromatograma da mistura padrão de ácidos graxos. Condições cromatográficas: coluna de fase reversa Shim-pack CLC-C $C_{8} 4,6 \mathrm{~mm}$ i.d. x $25 \mathrm{~cm}$ com partículas de $5 \mu \mathrm{m}$, precedidas de pré-coluna (Shim-pack G-ODS 8,0 mm i.d.x 1,5 $\mathrm{cm}$ ); fase móvel ACN:Água (73:23); vazão $0,5 \mathrm{~mL} / \mathrm{min}$; volume de injeção $40 \mu \mathrm{L}$; detector de fluorescência; temperatura ambiente $\pm 25^{\circ} \mathrm{C}$; equipamento cromatógrafo líquido Shimadzu. 
A composição de ácidos graxos do óleo de Castanha do Brasil obtida por este método demonstrou uma insaturação elevada (86,37\%).

Com base nos resultados obtidos pelo método de CLAE (Figura 14), observou-se que os ácidos graxos predominantes no óleo de Castanha do Brasil estão de acordo com os resultados obtidos em CG, porém a concentração e os tempos de retenção dos ácidos graxos obtidos por este método se apresentaram diferentes comparados ao método de CG (Tabela 8). Os tempos de retenção dos ácidos graxos obtidos pela CLAE foram superiores ao método de CG e este fato inviabilizou o uso desse método para quantificação dos ácidos graxos nas emulsões desenvolvidas neste trabalho.

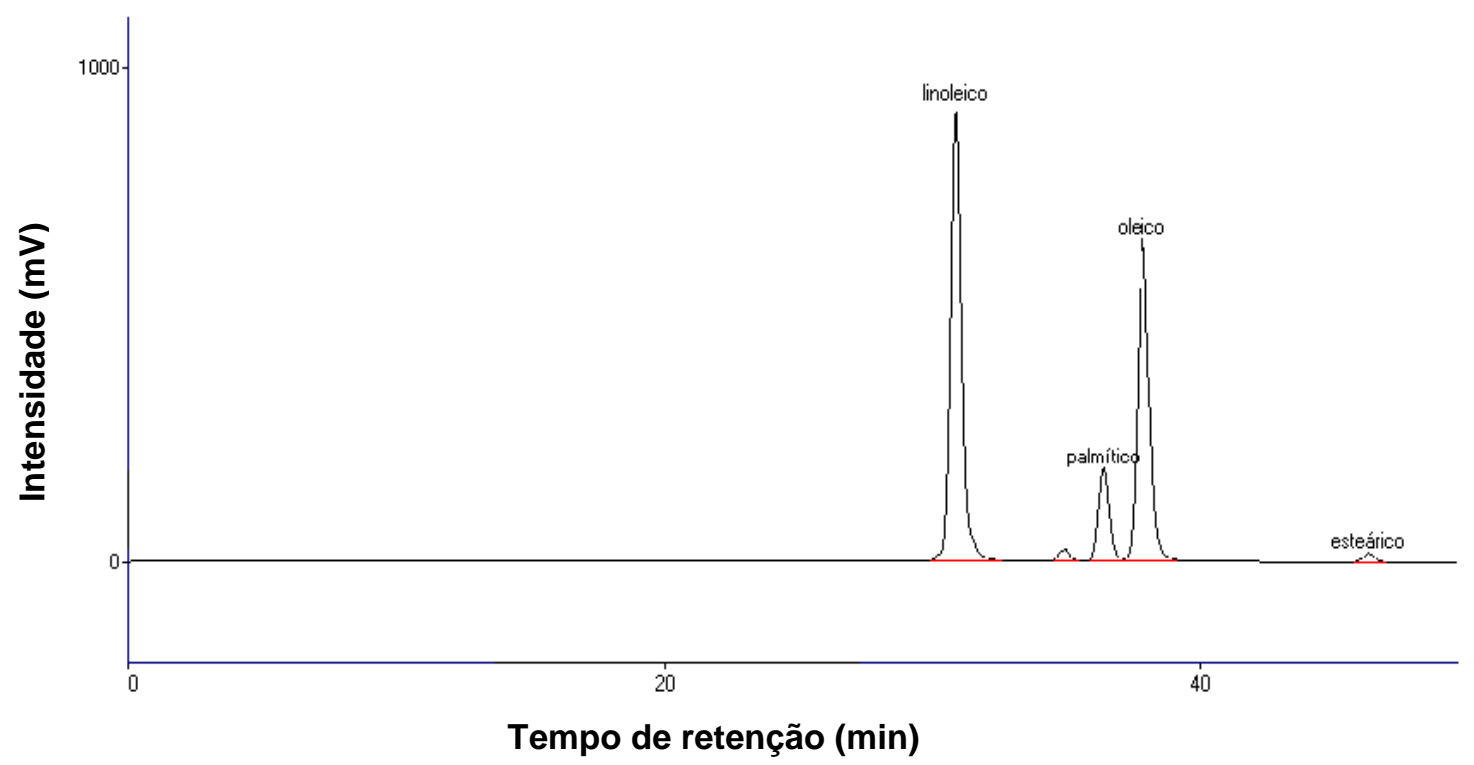

Figura 14: Cromatograma dos ácidos graxos do óleo de Castanha do Brasil. Condições cromatográficas: coluna de fase reversa Shim-pack CLC- $C_{8} 4,6 \mathrm{~mm}$ i.d. $x$ $25 \mathrm{~cm}$ com partículas de $5 \mu \mathrm{m}$, precedidas de pré-coluna (Shim-pack G-ODS 8,0 mm i.d.x 1,5 cm); fase móvel ACN:Água (73:23); vazão $0,5 \mathrm{~mL} / \mathrm{min}$; volume de injeção 40 $\mu \mathrm{L}$; detector de fluorescência; temperatura ambiente $\pm 25^{\circ} \mathrm{C}$; equipamento cromatógrafo líquido Shimadzu. 
Tabela 8: Áreas dos picos e composição em ácidos graxos do óleo de Castanha do Brasil identificados pelo método de cromatografia em fase líquida de alta eficiência.

\begin{tabular}{lcc}
\hline \hline \multicolumn{1}{c}{ Ácido graxo } & Área & Concentração (\%) \\
\hline \hline Palmítico & 5916172,5 & $12,34 \pm 2,71$ \\
Esteárico & 700573,5 & $1,48 \pm 0,55$ \\
Linoléico & 23673684,5 & $48,68 \pm 1,77$ \\
Oléico & 18225026 & $37,50 \pm 0,95$ \\
\hline \hline
\end{tabular}

\subsection{Eletroforese capilar (EC)}

Todos os parâmetros capazes de influenciar a separação eletroforética, devem ser otimizados durante o desenvolvimento do método. Os principais e mais comumente considerados são: seleção do eletrólito e seu pH, determinação da diferença de potencial a ser aplicada, escolha do capilar, temperatura de análise, comprimento de onda ideal e de tempos de injeção da amostra.

\subsubsection{Escolha do tipo de eletroforese}

Dentro das modalidades de eletroforese capilar, as mais simples e mais usadas são cromatografia capilar eletrocinética micelar (MEKC) e eletroforese capilar em solução livre (FSCE), sendo que a utilização de FSCE fica restrita à separação de compostos com carga enquanto MEKC é mais utilizada para separação de compostos tanto eletricamente carregados quanto neutros de caráter mais lipofílico (BAKER, 1995).

A utilização de eletroforese capilar de zona (CZE) para determinação de ácidos graxos tem sido limitada devido a esses compostos possuírem baixa absortividade UV. Eletrólitos aquosos são utilizados para contornar esses problemas na determinação de ácidos graxos $\mathrm{C}_{2}-\mathrm{C}_{14}$ por este modo de eletroforese capilar. No entanto, os ácidos graxos com cadeia carbônica maior que $\mathrm{C}_{17}$ possuem necessidade de utilizar MEKC (DRANGE \& LUNDANES, 1995). 
Como no presente trabalho é investigada a separação de ácidos graxos $\mathrm{C}_{16^{-}}$ $\mathrm{C}_{18}$, optou-se por utilizar a eletroforese capilar no modo MEKC.

\subsubsection{Seleção do capilar}

As dimensões dos capilares mais utilizados atualmente variam entre 25 e 100 $\mathrm{cm}$ de comprimento e entre 25 a $100 \mu \mathrm{m}$ de diâmetro interno. Quanto à composição, os materiais mais comuns são: os de vidro tipo Pirex, os de teflon e os de sílica fundida, cada um com suas vantagens. Os de sílica fundida, em geral são os mais utilizados, são oticamente transparentes, mas pouco resistentes e para aumentar sua resistência são comumente recobertos por uma fina camada externa de poliimida (BAKER, 1995). Ao realizar a escolha do capilar deve se considerar o diâmetro interno do mesmo, pois quanto maior, mais calor será gerado e maior será a diferença de temperatura (e, portanto de FEO) entre o centro e as paredes do capilar e quanto maior o comprimento, maior será o tempo de análise.

Um capilar de sílica fundida recoberto por poliimida foi escolhido, por ser 0 material mais utilizado. Após testes preliminares, observou-se que a separação total dos compostos aqui estudados se dá em capilares com comprimentos maiores que $50 \mathrm{~cm}$. Optou-se, por este motivo, utilizar um capilar com comprimento total de 60,2 $\mathrm{cm}$, tendo 50,0 cm efetivos (até o detector). Foram testados capilares com diâmetros internos de 50 e $75 \mu \mathrm{m}$. Os testes demonstraram que o capilar que possuía $50 \mu \mathrm{m}$ de diâmetro interno apresentou freqüente queda de corrente. Esse fato impossibilitou as análises. Portanto, foi escolhido o capilar com diâmetro interno de $75 \mu \mathrm{m}$.

\subsubsection{Seleção do $\mathrm{pH}$ do eletrólito}

A primeira avaliação realizada foi para definir o melhor $\mathrm{pH}$ para separação dos ácidos graxos, pois este influencia significativamente o fluxo eletrosmótico, alterando tempo de migração e seletividade. Teoricamente para uma melhor resolução o pH ótimo é próximo ao pka dos solutos em questão, pois as diferenças de ionização são máximas levando às migrações diferenciadas (BAKER, 1995). A composição do tampão pode alterar o tempo de retenção e a seletividade, pois 
diferentes íons interagem de forma diferente com a parede do capilar e podem alterar o fluxo eletrosmótico (BAKER, 1995).

No presente trabalho, os testes foram conduzidos em $\mathrm{pH} 7,0$, utilizando 0 tampão tetraborato de sódio $12,5 \mathrm{mmol} \mathrm{L}^{-1}$, pois neste valor de $\mathrm{pH}$, os ácidos graxos se apresentam desprotonados, uma vez que seus respectivos pKa estão em torno de 5. Desta maneira, eles se comportam predominantemente como ânions e pela sua própria mobilidade eletroforética tendem a migrar no sentido do ânodo (positivo), posicionado no lado da injeção. Neste $\mathrm{pH}$, o fluxo eletrosmótico é suficientemente maior para vencer a velocidade eletroforética $\left(\mathrm{V}_{\mathrm{ep}}\right)$ dos ácidos graxos que vão em direção do ânodo os quais são arrastados na direção do cátodo (negativo), posicionado após a janela de detecção, ou seja, no detector posicionado em linha a frente do reservatório de saída. Como os ácidos graxos apresentam baixa absorbância, em $224 \mathrm{~nm}$ pela ausência de centros cromóforos, pelo uso de agentes cromóforos estes acabam deslocando o sinal do detector e os picos saem para baixo (OLIVEIRA, 2003).

\subsubsection{Seleção do cromóforo}

Como citado acima, os ácidos graxos não possuem fortes grupos cromóforos em suas estruturas e, portanto, possuem baixa absorção em UV. Portanto, se fez necessário um estudo para a escolha do melhor cromóforo para a análise dos compostos em questão. Foram testados os seguintes agentes cromóforos imidazol, quinina, benzeno, fenol, histidina e SDBS, mas o único que obteve sucesso foi o último citado.

\subsubsection{Influência de solventes orgânicos}

A adição de solventes orgânicos altera o fluxo eletrosmótico (FEO) por alterar a viscosidade do eletrólito; pela equação do cálculo do FEO se sabe que este é inversamente proporcional à viscosidade do eletrólito; assim solventes orgânicos capazes de alterar a viscosidade do eletrólito, promovem alteração no FEO. Foram testadas as influências dos seguintes solventes orgânicos: acetonitrila (ACN), metanol, 1-butanol, isopropanol (IPA) e tetrahidrofurano (THF) em diferentes concentrações. 
A escolha destes solventes orgânicos também foi visando aumentar a solubilidade dos ácidos graxos em estudo no eletrólito, já que não são solúveis em água e solúveis em solventes orgânicos. Os solventes foram testados em concentrações variando de 10 a $40 \%$.

Acetonitrila foi o solvente orgânico escolhido para o estudo, pois apresentou boa separação dos ácidos graxos. Porém se fez necessário um estudo para o ajuste de concentração deste solvente, uma vez que, com o aumento da concentração deste, se observou um aumento no ruído da linha de base e nos tempos de migração e até mesmo na separação completa dos analitos. Esta observação corrobora com o estudo de Oliveira e colaboradores, que separou ácidos graxos utilizando ACN como solvente, otimizando assim um eletrólito onde a concentração deste solvente foi de $45 \%$, relatando que acima desta concentração a separação destes compostos se torna comprometida (OLIVEIRA et al., 2004). Segundo Oliveira e colaboradores, acetonitrila reduz o fluxo eletrosmótico e provoca retenção reduzida e uma melhoria na nitidez do pico. Acetonitrila também permite a análise da seletividade cromatográfica, que é uma questão importante para a avaliação de métodos alternativos de separação (OLIVEIRA et al. 2003).

Metanol, 1-butanol, THF e IPA foram descartados, pois não apresentaram sucesso na separação dos ácidos.

\subsubsection{Tempo injeção da amostra}

Em eletroforese capilar os tipos mais comumente utilizados para a introdução da amostra são os seguintes: injeção eletrocinética e gravitacional ou hidrodinâmica. A forma de injeção depende do equipamento utilizado. $O$ equipamento utilizado possui as duas opções mas a escolhida foi a injeção hidrodinâmica (por pressão) para obter uma melhor reprodutibilidade no volume de injeção dos analitos. Neste tipo de injeção a amostra ingressa ao capilar devido a uma diferença de pressão aplicada sobre o vial que contêm a amostra quando o capilar se encontra submerso. Os volumes comumente utilizados em EC variam de 1-20 $\mu \mathrm{L}$. Para $\circ$ presente método foram testados diferentes tempos de injeção.

Testes preliminares iniciaram-se fixando uma voltagem em $20 \mathrm{kV}$ e a pressão de injeção em 0,5 psi a fim de testar o variável tempo de injeção. Observou-se que quando o tempo de injeção foi maior do que $3 \mathrm{~s}$, para essas condições, resultou em 
uma separação parcial dos ácidos graxos. Ao tempo de $6 \mathrm{~s}$, por exemplo, todos os quatro ácidos primeiramente testados (palmítico, esteárico, oléico e linoléico) se encontravam co-eluídos. Comparando as figuras 15(a) e 15(b) a 6 e 3 s de injeção, respectivamente, observou-se que com o aumento do tempo de injeção um maior volume de amostra foi injetado prejudicando a separação total dos compostos.

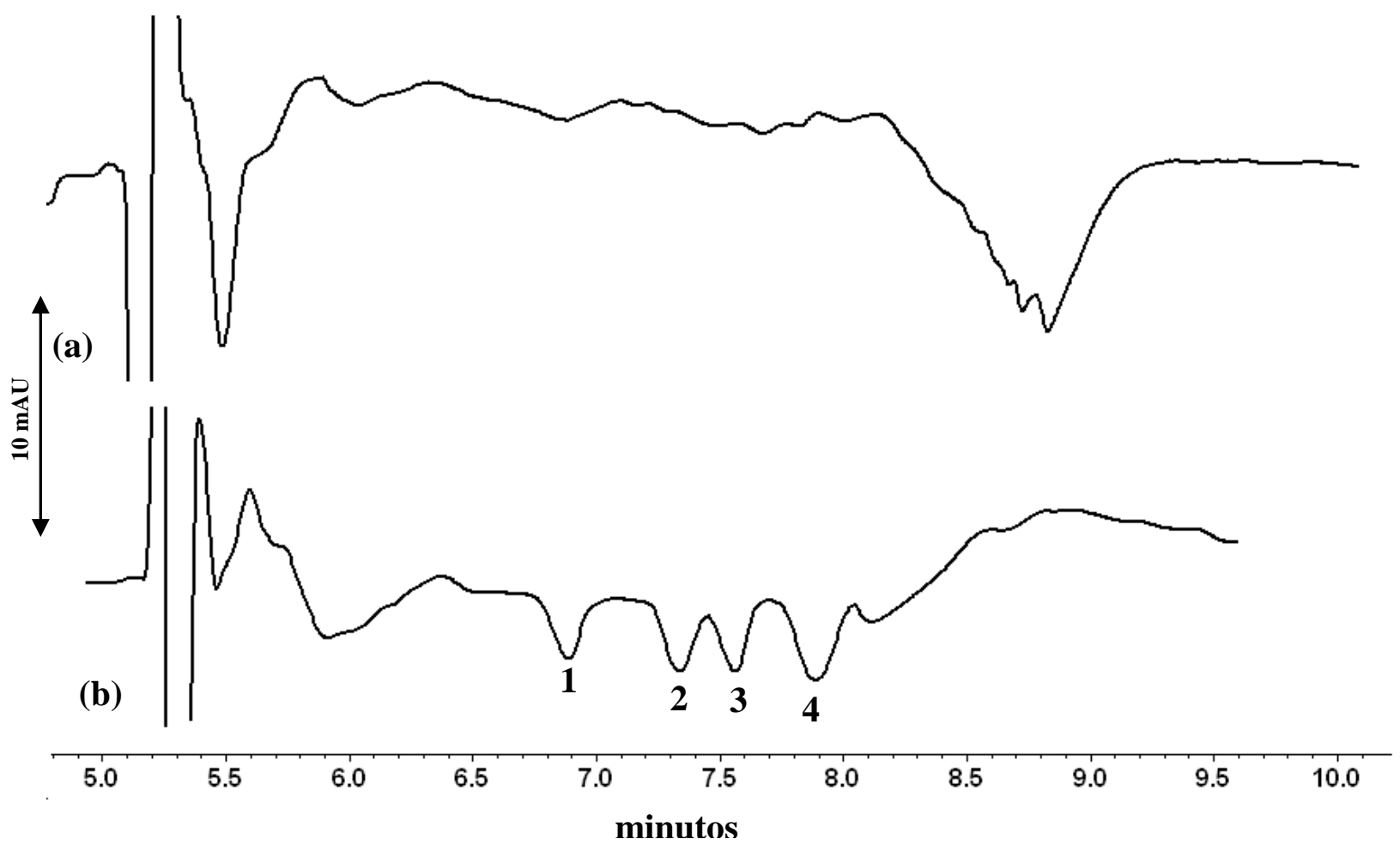

Figura 15: Eletroferograma da separação de uma mistura padrão de ácidos graxos dissolvidos em metanol $\left(0,25 \mathrm{mmol} \mathrm{L}^{-1}\right)$ : (1) esteárico, (2) oléico, (3) palmítico e (4) linoléico, utilizando como eletrólito $12,5 \mathrm{mmol} / \mathrm{L}$ de tetraborato de sódio $\mathrm{pH} 7,0 ; 35 \%$ (v/v) ACN; $12,5 \mathrm{mmol} / \mathrm{L}$ Brij 35; 7,5 mmol/L SDBS. Capilar de $62 \mathrm{~cm}(50,2 \mathrm{~cm}$ até 0 detector) e $75 \mu \mathrm{m}$ de d.i. (a) Voltagem aplicada: $+20 \mathrm{kV}$. Injeção hidrodinâmica 0,5 psi por $6 s, 25^{\circ} \mathrm{C}$. (b) Voltagem aplicada: $+20 \mathrm{kV}$. Injeção hidrodinâmica 0,5 psi por $3 \mathrm{~s}, 25^{\circ} \mathrm{C}$.

Escolhendo o tempo de injeção de $3 \mathrm{~s}$ (que foi o melhor resultado, acima demonstrado) e voltagem em $+25 \mathrm{kV}$, testou-se a variável pressão de injeção. Comparando-se os dois eletroferogramas das Figuras 16(a) a 0,5 psi e 16(b) a 0,3 psi, observou-se uma diferença na estabilidade nas linhas de base, porém os ácidos oléico e palmítico ainda co-eluíram. O próximo passo foi avaliar a voltagem a fim de separar definitivamente os compostos que ainda se encontravam co-eluídos. 


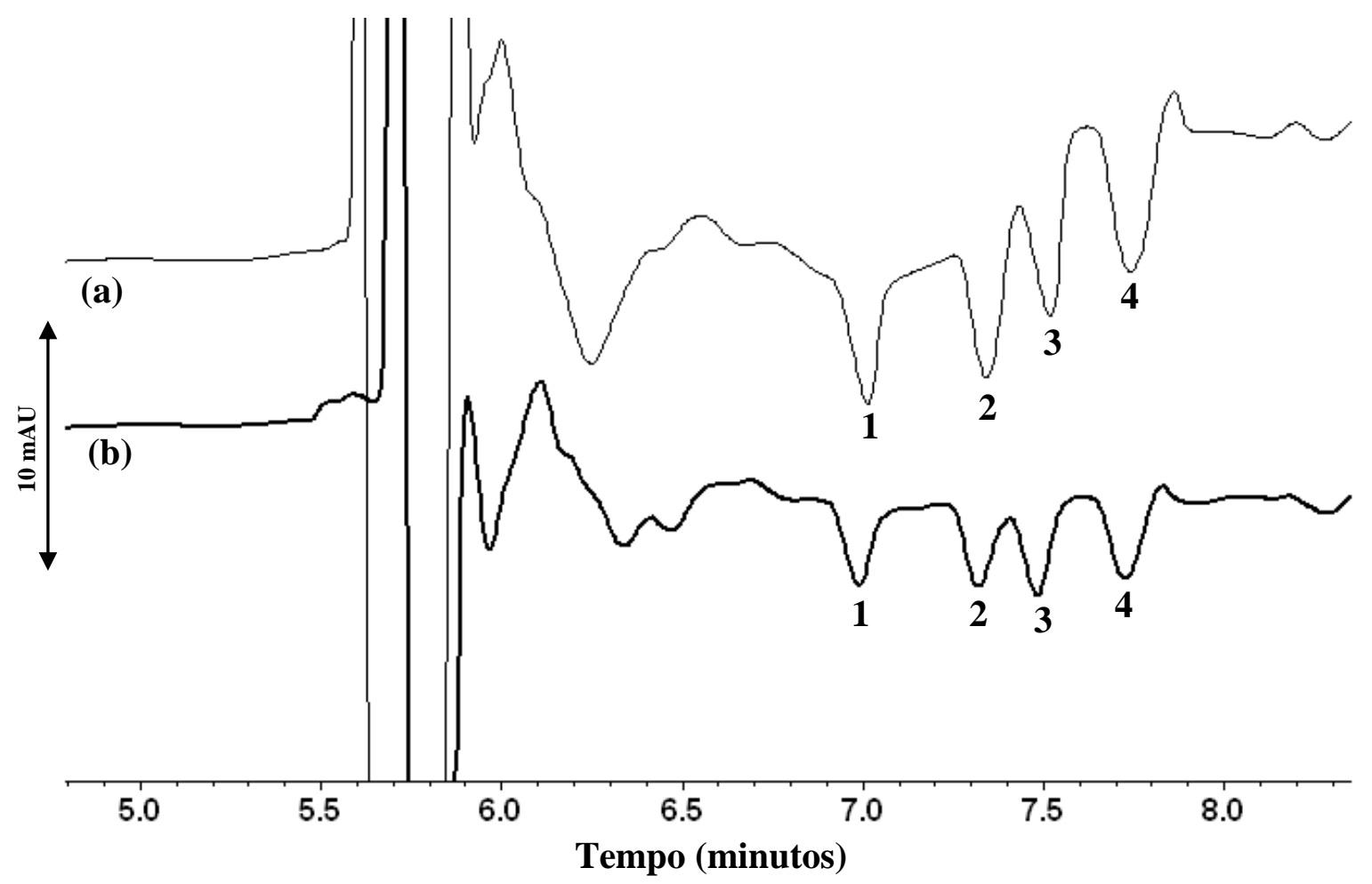

Figura 16. Eletroferograma da separação de uma mistura padrão de ácidos graxos dissolvidos em metanol: (1) esteárico, (2) oléico, (3) palmítico e (4) linoléico, utilizando como eletrólito $12,5 \mathrm{mmol} \mathrm{L}^{-1}$ de tetraborato de sódio $\mathrm{pH} 7,0 ; 35 \%(\mathrm{v} / \mathrm{v})$ ACN; $12,5 \mathrm{mmol} \mathrm{L}^{-1}$ Brij 35; $7,5 \mathrm{mmol} \mathrm{L}^{-1}$ SDBS. Capilar de $62 \mathrm{~cm}(50 \mathrm{~cm}$ até o detector) e $75 \mu \mathrm{m}$ de d.i. (a) Voltagem aplicada: $+25 \mathrm{kV}$. Injeção hidrodinâmica 0,5 psi por $3 \mathrm{~s}, 25^{\circ} \mathrm{C}$. (b) Voltagem aplicada: $+25 \mathrm{kV}$. Injeção hidrodinâmica 0,3 psi por $3 \mathrm{~s}, 25^{\circ} \mathrm{C}$. Concentração de cada ácido graxo: $250,0 \mu \mathrm{g} \mathrm{m}^{-1}$.

\subsubsection{Determinação da voltagem}

A voltagem foi ajustada para manter a separação dos compostos em um menor tempo de retenção possível sem que interferisse em outros parâmetros que pudesse vir a prejudicar os resultados na separação dos compostos. As variáveis tempo de injeção igual a 3 s e pressão de injeção igual a 0,3 psi foram fixadas para avaliação da variável voltagem. Observou-se que os experimentos conduzidos a +25 $\mathrm{kV}$, os ácidos oléico e palmítico se encontravam co-eluídos [Figura 17(a)]. Já os experimentos conduzidos à $20 \mathrm{kV}$, sob estas condições, apresentaram uma separação total dos ácidos graxos [Figura 17(b)]. O valor da corrente obtida foi próximo a $50 \mu \mathrm{A}$. De acordo com os resultados demonstrados, as condições otimizadas se mostraram adequadas para a finalização do desenvolvimento do método em questão. 


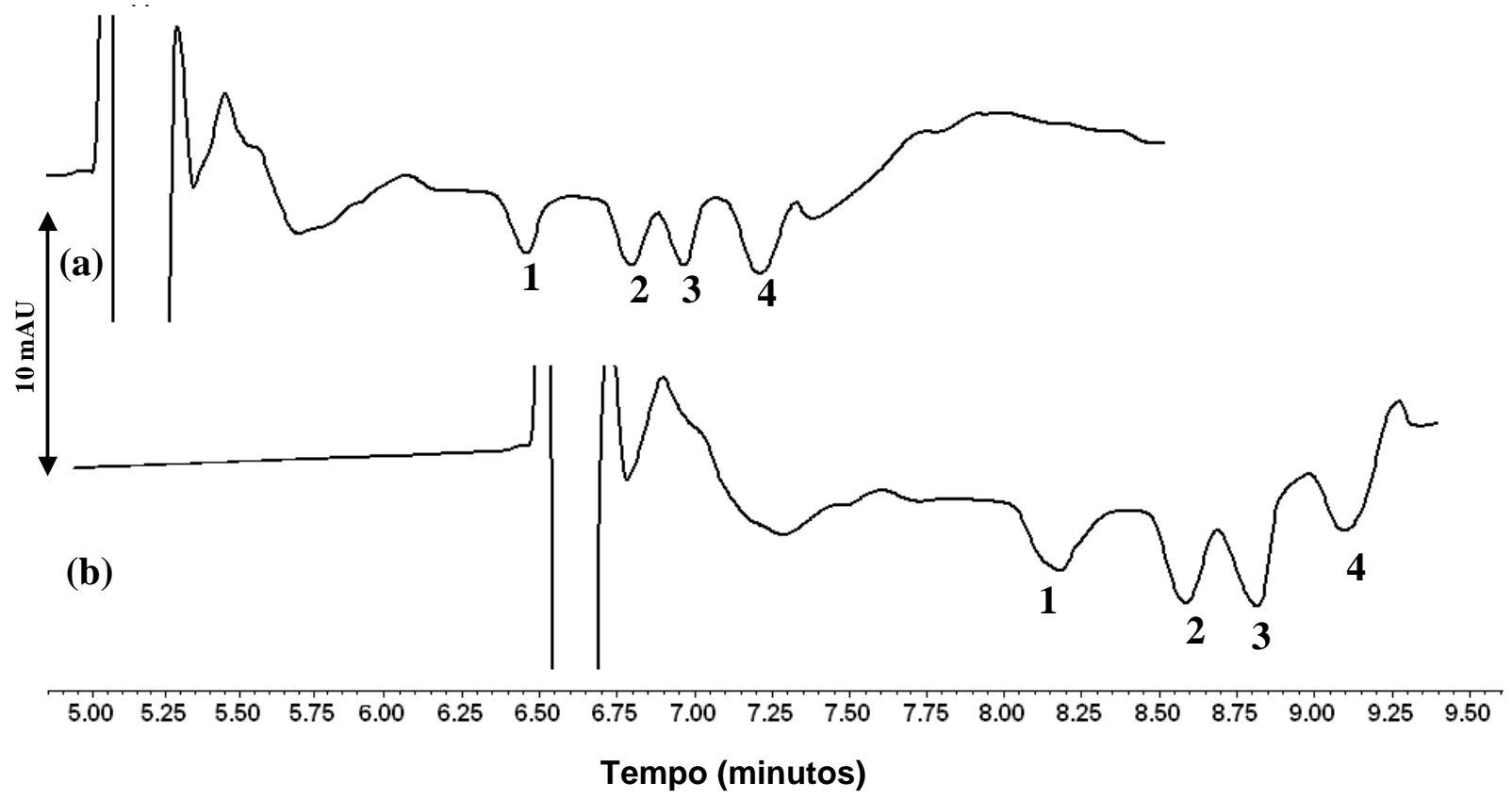

Figura 17: Eletroferograma da separação de uma mistura padrão de ácidos graxos dissolvidos em metanol $\left(0,25 \mathrm{mmol} \mathrm{L}^{-1}\right)$ : (1) esteárico, (2) oléico, (3) palmítico e (4) linoléico, utilizando como eletrólito $12,5 \mathrm{mmol} / \mathrm{L}$ de tetraborato de sódio $\mathrm{pH} 7,0 ; 35 \%$ (v/v) ACN; $12,5 \mathrm{mmol} / \mathrm{L}$ Brij 35; 7,5 mmol/L SDBS. Capilar de $62 \mathrm{~cm}(50,2 \mathrm{~cm}$ até o detector) e $75 \mu \mathrm{m}$ de d.i. (a) Voltagem aplicada: $+25 \mathrm{kV}$. Injeção hidrodinâmica 0,5 psi por $3 \mathrm{~s}, 25^{\circ} \mathrm{C}$. (b) Voltagem aplicada: $+20 \mathrm{kV}$. Injeção hidrodinâmica 0,5 psi por $3 \mathrm{~s}, 25^{\circ} \mathrm{C}$.

\subsubsection{Pré-tratamento da amostra}

Este parâmetro também deve ser otimizado, pois altas concentrações do analito podem levar à distorção dos picos e partículas presentes na amostra podem entupir o capilar. $O$ tempo de injeção deve ser ajustado conjuntamente ao ajuste da concentração de trabalho, pois deste depende a quantidade de amostra injetada (ALTRIA, 1996).

As soluções estoque dos ácidos graxos foram preparadas apenas em metanol e armazenados no freezer. Para o desenvolvimento e otimização do método, foram utilizadas soluções de concentração de trabalho de 2000 $\mu \mathrm{g} \mathrm{mL}{ }^{-1}$ para cada ácido graxo obtidas a partir das soluções estoque.

\subsubsection{Pré-condicionamento do capilar}

O pré-condicionamento é fundamental para manter a consistência do fluxo eletrosmótico entre cada corrida e como qualquer variação deste pode levar a uma 
baixa precisão nos tempos de migração (ALTRIA, 1996; BAKER, 1995), este procedimento se torna fundamental para a precisão do método. $O$ précondicionamento comumente utilizado é de 15 minutos de lavagem com solução 0,1 mol L ${ }^{-1}$ de $\mathrm{NaOH}$, o que é suficiente para recompor a parede do capilar seguida de uma lavagem de 15 minutos com água deionizada, e por último uma lavagem por 10 minutos com o eletrólito de corrida antes da injeção para evitar alteração no $\mathrm{pH}$ inicial da corrida (ALTRIA; 1996). Este foi o pré-condicionamento inicialmente testado, mas problemas de uma possível adsorção de alguns dos compostos utilizados nas paredes do capilar apareceram, então foi necessário realizar uma lavagem mais drástica utilizando também metanol. Para garantir condições em relação ao capilar uma lavagem rinsagem de 3,5 minutos de metanol, seguida de 1,5 minutos com $\mathrm{NaOH} 0,1 \mathrm{~mol} \mathrm{~L}^{-1}$ e por último 1,5 minutos com água deionizada, foram realizadas em cada injeção.

\subsubsection{Utilização do eletrólito - Reposição}

Após varias corridas a composição do eletrólito contido no vial de saída, pode ter sido alterado pela depletação do mesmo, assim para a melhor repetibilidade é necessário trocar com freqüência os recipientes (viais) contendo de eletrólito. A freqüência de troca recomendada é a cada corrida, mas na prática depende das condições do eletrólito.

Em função das características apresentadas no item da revisão bibliográfica, (vide item 2), foram elaborados experimentos conjugando a utilização de alguns solventes orgânicos e cromóforos já descritos no item 5.2. Optou-se, portanto, por trabalhar com o seguinte eletrólito constituído dos seguintes compostos: SDBS como agente cromóforo, tampão tetraborato $(\mathrm{pH} 7), \mathrm{ACN}$ como solvente orgânico e Brij 35 como tensoativo.

A Figura 18 representa o método otimizado para a separação de uma mistura padrão de ácidos graxos. Observa-se, nessa Figura, uma linha base boa para os padrões e estes se apresentam bem separados. 


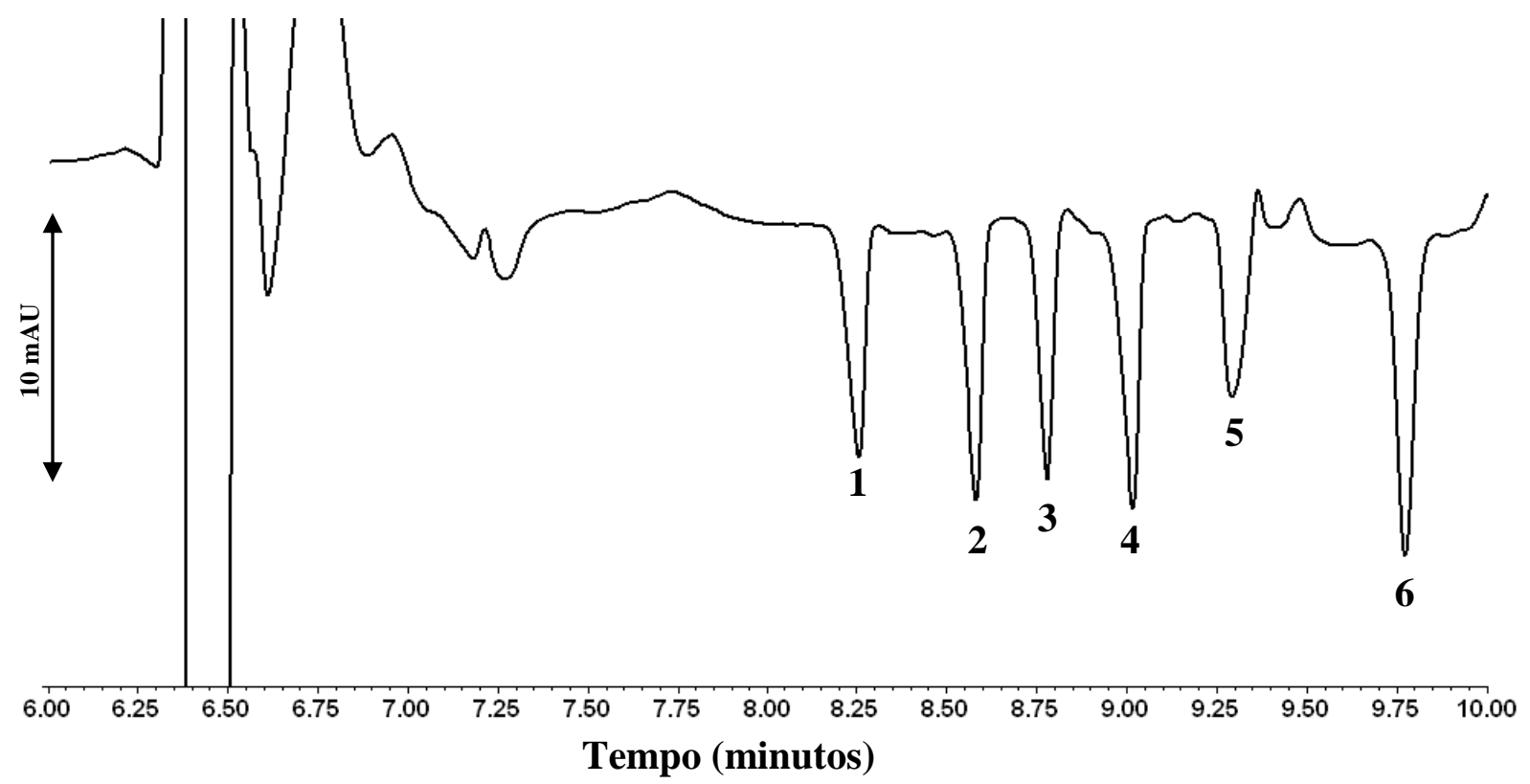

Figura 18: Eletroferograma da separação de uma mistura padrão de ácidos graxos dissolvidos em metanol $\left(0,25 \mathrm{mmol} \mathrm{L}^{-1}\right)$ : (1) esteárico, (2) margárico (padrão interno), (3) oléico e (4) palmítico, (5) linoléico e (6) linolênico, utilizando como eletrólito 12,5 $\mathrm{mmol} / \mathrm{L}$ de tetraborato de sódio $\mathrm{pH} 7,0 ; 35 \%(\mathrm{v} / \mathrm{v}) \mathrm{ACN} ; 12,5 \mathrm{mmol} / \mathrm{L}$ Brij $35 ; 7,5$ $\mathrm{mmol} / \mathrm{L}$ SDBS. Capilar de $62 \mathrm{~cm}(50,2 \mathrm{~cm}$ até o detector) e $75 \mu \mathrm{m}$ de d.i. Voltagem aplicada: +20 kV. Injeção hidrodinâmica 0,3 psi por $3 s, 25^{\circ} \mathrm{C}$.

A fim de demonstrar a aplicabilidade do método proposto e identificar os ácidos graxos do óleo de Castanha do Brasil nas formulações, o óleo de Castanha do Brasil e as formulações cosméticas foram analisados.

A Figura 19 mostra os ácidos graxos identificados no óleo de Castanha do Brasil. Esse resultado corrobora com a literatura (vide item 2, Tabela 4, pág. 34). Pelo eletroferograma pode-se observar que o sinal do ácido linoléico é o mais forte, seguido dos ácidos oléico, palmítico e esteárico, respectivamente.

O método mostrou que é possível identificar o óleo de Castanha do Brasil no gel-creme. Isso porque são conhecidas todas as matérias-primas utilizadas na preparação do cosmético. Em outras palavras, não foram identificados ácidos graxos provenientes de outras matérias-primas utilizadas (Figura 20). 


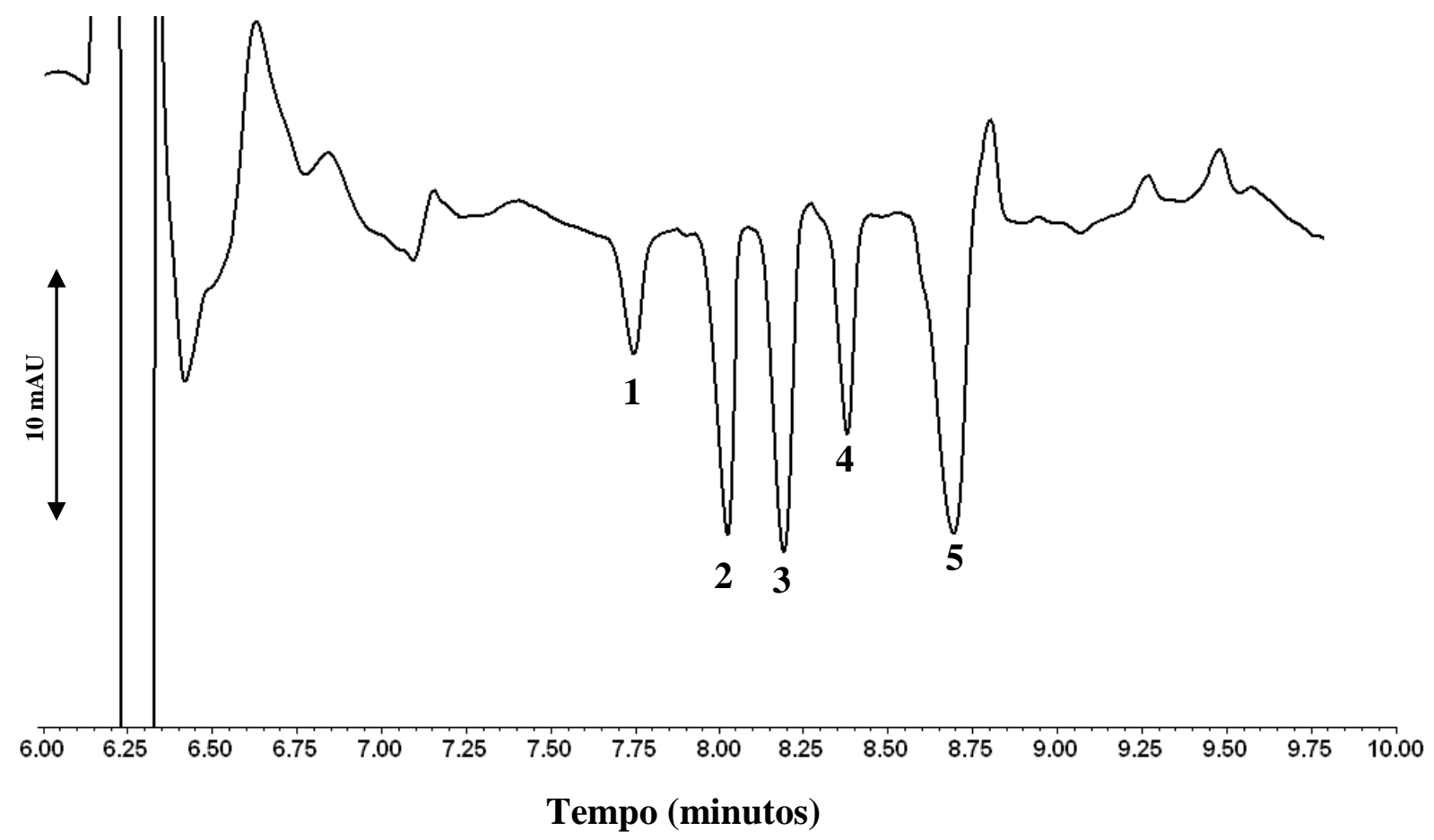

Figura 19: Eletroferograma dos ácidos graxos encontrados no óleo de Castanha do Brasil extra-virgem (1) esteárico, (2) margárico (padrão interno), (3) oléico e (4) palmítico e (5) linoléico, utilizando como eletrólito $12,5 \mathrm{mmol} / \mathrm{L}$ de tetraborato de sódio $\mathrm{pH} 7,0 ; 35 \%(\mathrm{v} / \mathrm{v})$ acetonitrila; $12,5 \mathrm{mmol} / \mathrm{L}$ Brij 35; 7,5 mmol/L SDBS. Capilar de $62 \mathrm{~cm}(50,2 \mathrm{~cm}$ até $\mathrm{o}$ detector $)$ e $75 \mu \mathrm{m}$ de d.i. Voltagem aplicada: $+20 \mathrm{kV}$. Injeção hidrodinâmica 0,3 psi por $3 \mathrm{~s}, 25^{\circ} \mathrm{C}$.

Esta constatação verificada quando da análise do gel-creme base, onde não foi identificado nenhum sinal de interferência em sua composição (Figura 21).

Como foram identificados todos os ácidos graxos constituintes em maior proporção no óleo de Castanha do Brasil, é válido lembrar que é utilizado $5 \%$ de óleo de Castanha do Brasil na formulação. O ácido esteárico, por exemplo, que é encontrado em aproximadamente $8 \%$ (menor proporção que os outros ácidos) foi identificado. Esse fato nos leva a considerar a eletroforese como uma aliada no controle de qualidade de óleos, uma vez que foi possível detectar no mínimo 0,4 g deste ácido na formulação cosmética. 


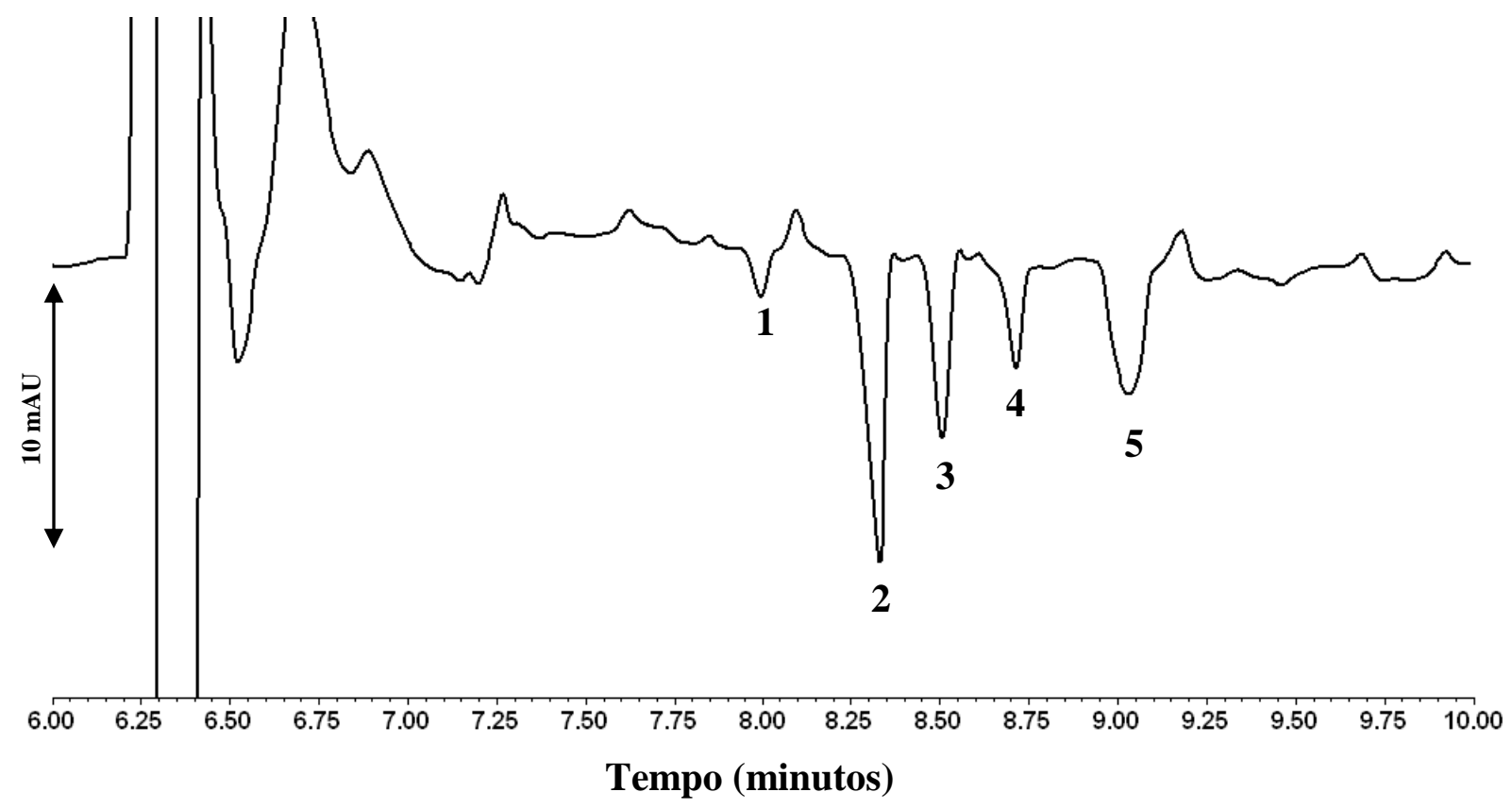

Figura 20: Eletroferograma da separação dos ácidos graxos (1) esteárico, (2) oléico e (3) palmítico e (4) linoléico identificados na fase oleosa extraída da formulação cosmética contendo o óleo de Castanha do Brasil desenvolvida utilizando como eletrólito $12,5 \mathrm{mmol} / \mathrm{L}$ de tetraborato de sódio $\mathrm{pH} 7,0 ; 35 \%(\mathrm{v} / \mathrm{v}) \mathrm{ACN} ; 12,5 \mathrm{mmol} / \mathrm{L}$ Brij 35; 7,5 mmol/L SDBS. Capilar de $62 \mathrm{~cm}(50,2 \mathrm{~cm}$ até o detector) e $75 \mu \mathrm{m}$ de d.i. Potencial aplicado: +20 kV. Injeção hidrodinâmica 0,3 psi por 3s, 25ㄷ.

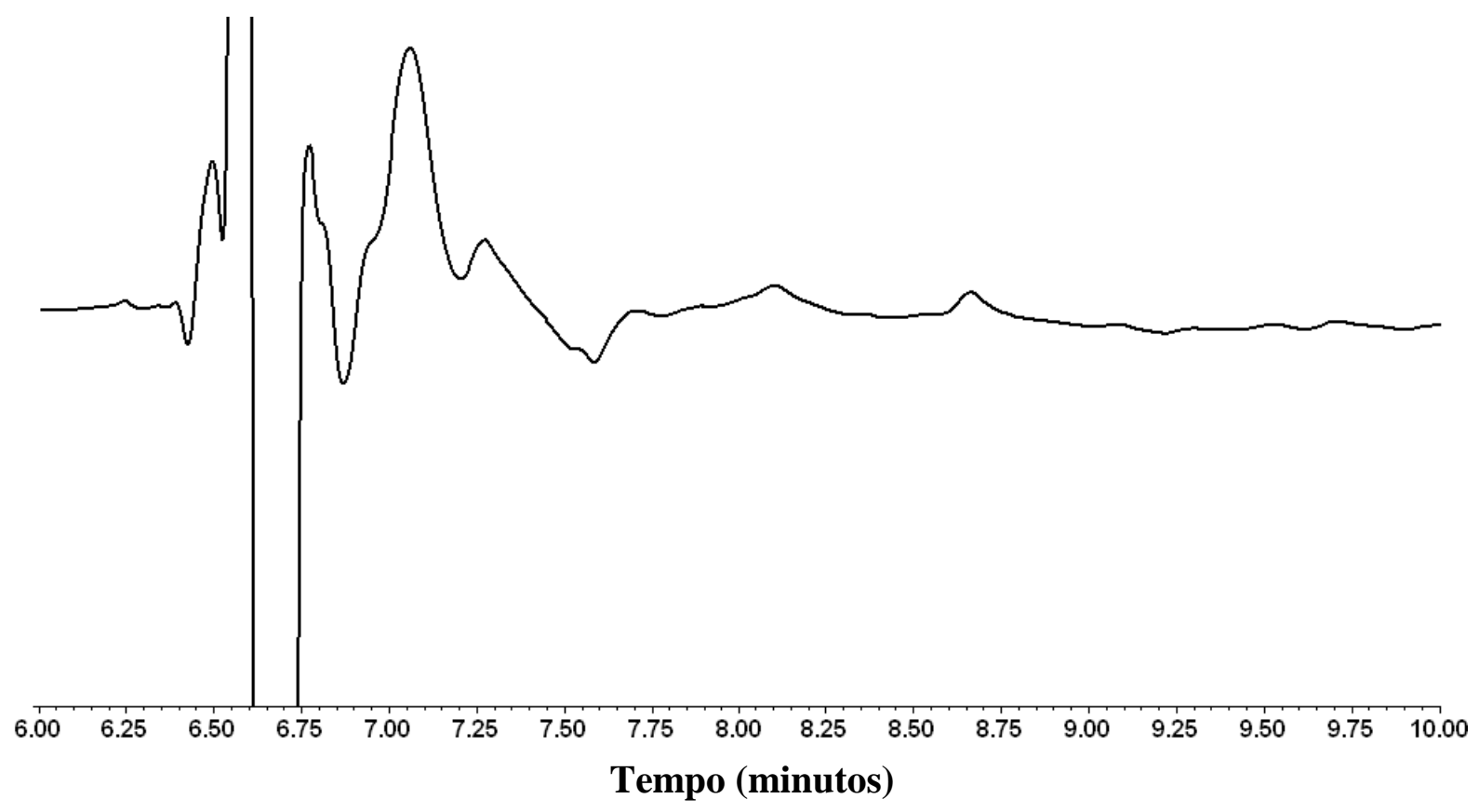

Figura 21: Eletroferograma da fase oleosa extraída da formulação base desenvolvida utilizando como eletrólito $12,5 \mathrm{mmol} / \mathrm{L}$ de tetraborato de sódio $\mathrm{pH} \mathrm{7,0;}$ $35 \%$ (v/v) ACN; $12,5 \mathrm{mmol} / \mathrm{L}$ Brij 35; 7,5 mmol/L SDBS. Capilar de $62 \mathrm{~cm}(50,2 \mathrm{~cm}$ até o detector) e $75 \mu \mathrm{m}$ de d.i. Voltagem aplicada: $+20 \mathrm{kV}$. Injeção hidrodinâmica 0,3 psi por 3s, $25^{\circ} \mathrm{C}$. 
5.2.1.1. Estudo de interferentes na formulação cosmética base

Os excipientes utilizados na preparação da formulação foram submetidos à reação de saponificação para posterior injeção no equipamento de EC. Através de um estudo a respeito dessas substâncias, optou-se pela escolha das seguintes: Sepigel 305, Procetyl AWS, Triglicerpideos do ácido cáprico/caprílico e Phenova.

Os demais excipientes não foram escolhidos para o estudo de interferentes uma vez que são solúveis em água, portanto não se encontram na fase oleosa obtida da extração com clorofórmio. Esse procedimento foi utilizado com a finalidade de identificar possíveis ácidos graxos provenientes destas matérias-primas. Observou-se, pela figura 22 A, 22 B, 22 C e 22 D, que os excipientes empregados na preparação do gel-creme não apresentaram interferências que pudessem prejudicar na identificação dos ácidos graxos do óleo de Castanha do Brasil. Esse resultado infere na certeza de que foi possível identificar todos os ácidos graxos do óleo de Castanha do Brasil na formulação cosmética desenvolvida.

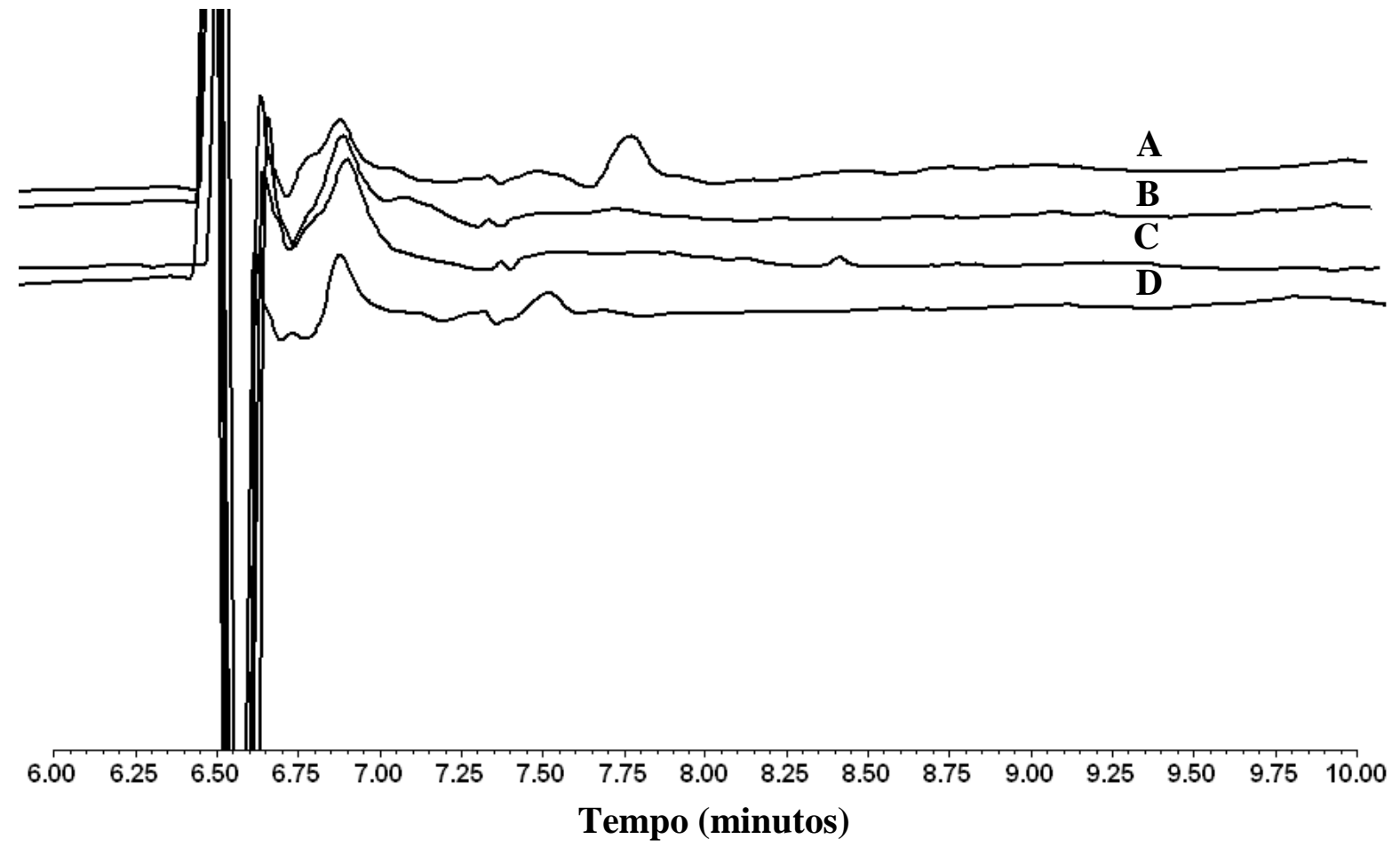

Figura 22: Eletroferograma do Procetyl AWS, Sepigel 305, Phenova e triglicerídeos do ácido cáprico/ caprílico; utilizando como eletrólito $12,5 \mathrm{mmol} / \mathrm{L}$ de tetraborato de sódio $\mathrm{pH} 7,0 ; 35 \%$ (v/v) ACN; $12,5 \mathrm{mmol} / \mathrm{L}$ Brij 35; 7,5 mmol/L SDBS. Capilar de 62 $\mathrm{cm}$ (50,2 $\mathrm{cm}$ até o detector) e $75 \mu \mathrm{m}$ de d.i. Potencial aplicado: $+20 \mathrm{kV}$. Injeção hidrodinâmica 0,3 psi por $3 s, 25^{\circ} \mathrm{C}$. 
O método também foi aplicado à uma amostra comercial que contém o óleo de Castanha do Brasil a fim de identificar os ácidos graxos estudados. De acordo com a Figura 23, apesar de uma instabilidade na linha de base do eletroferograma pode-se observar que foi possível identificar os ácidos graxos da formulação comercial.

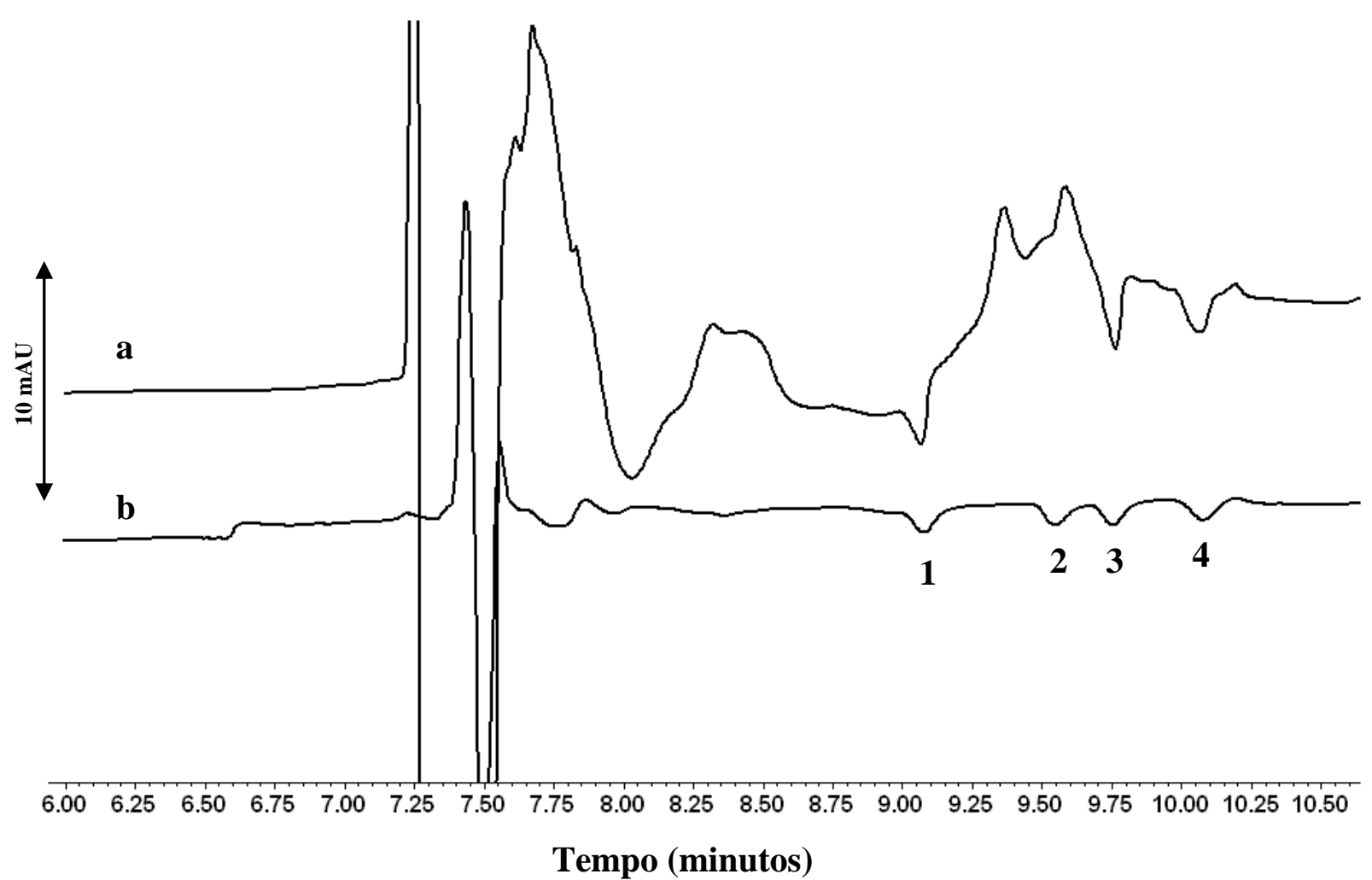

Figura 23: Eletroferogramas: (a) amostra comercial (creme hidratante); (b) mistura dos padrões dos ácidos graxos $\left(250,0 \mu \mathrm{g} \mathrm{mL}^{-1}\right)$ : (1) esteárico, (2) oléico e (3) palmítico e (4) linoléico, da utilizando como eletrólito $12,5 \mathrm{mmol} / \mathrm{L}$ de tetraborato de sódio $\mathrm{pH} 7,0 ; 35 \%$ (v/v) ACN; $12,5 \mathrm{mmol} / \mathrm{L}$ Brij 35; 7,5 mmol/L SDBS. Capilar de 62 $\mathrm{cm}(50,2 \mathrm{~cm}$ até o detector) e $75 \mu \mathrm{m}$ de d.i. Voltagem aplicada: +20 kV. Injeção hidrodinâmica 0,3 psi por $3 \mathrm{~s}, 25^{\circ} \mathrm{C}$.

5.2.12. Considerações a respeito de parâmetros do processo de validação do método desenvolvido por eletroforese capilar

Repetibilidade em tempo e área

Dez injeções consecutivas de uma mistura contendo os seis padrões de ácidos graxos foram realizadas: palmítico, margárico (padrão interno), esteárico, 
oléico, linoléico e linolênico na concentração de $0,25 \mathrm{mmol} \mathrm{L}^{-1}$. A Figura 24 apresenta os eletroferogramas obtidos para as injeções consecutivas.

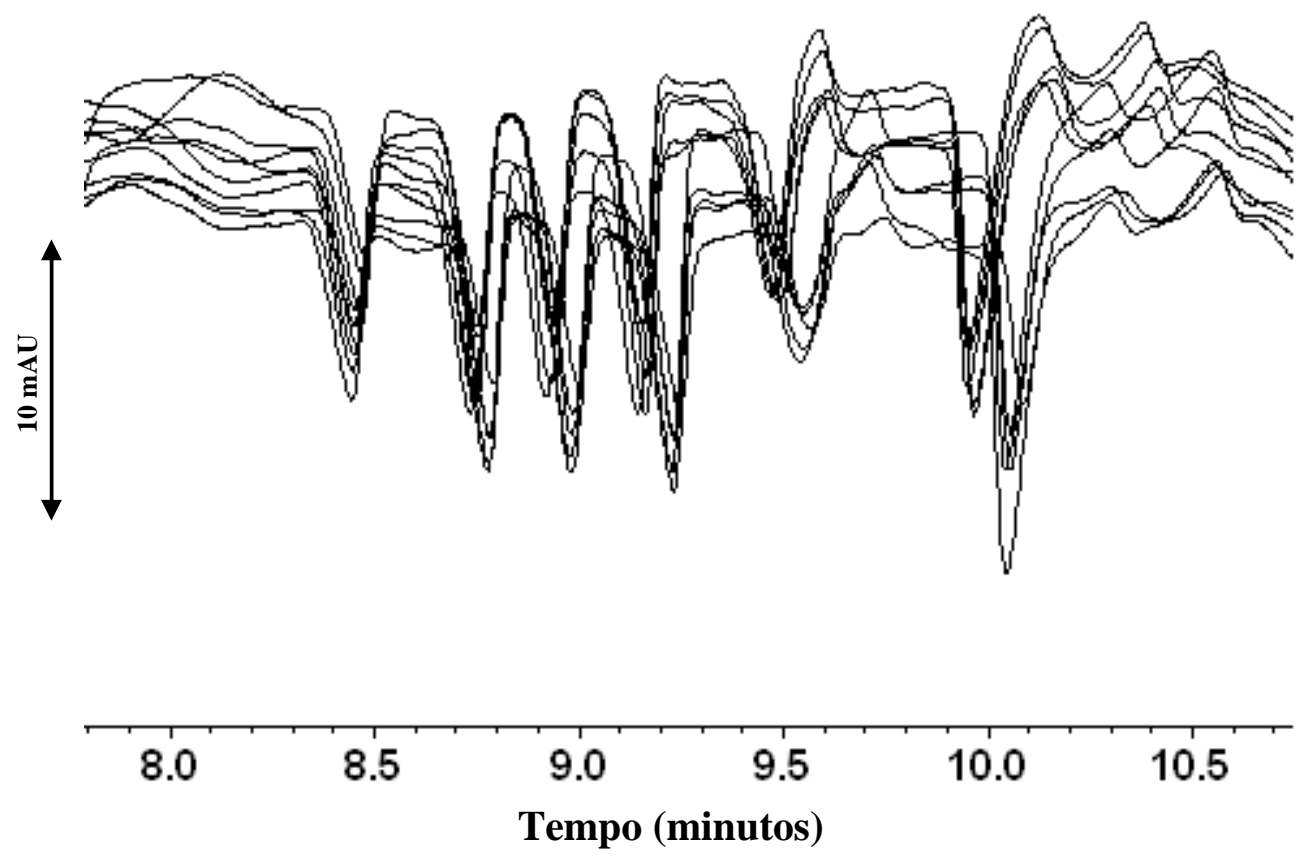

Figura 24: Eletroferograma de dez injeções consecutivas da separação de uma mistura padrão de ácidos graxos dissolvidos em metanol $\left(0,25 \mathrm{mmol} \mathrm{L}^{-1}\right)$ : (1) esteárico, (2) margárico (padrão interno), (3) oléico e (4) palmítico, (5) linoléico e (6) linolênico, utilizando como eletrólito $12,5 \mathrm{mmol} / \mathrm{L}$ de tetraborato de sódio $\mathrm{pH} 7,0$; $35 \%$ (v/v) ACN; $12,5 \mathrm{mmol} / \mathrm{L}$ Brij 35; 7,5 mmol/L SDBS. Capilar de $62 \mathrm{~cm}(50,2 \mathrm{~cm}$ até 0 detector) e $75 \mu \mathrm{m}$ de d.i. Voltagem aplicada: $+20 \mathrm{kV}$. Injeção hidrodinâmica 0,3 psi por 3s, $25^{\circ} \mathrm{C}$.

A Tabela 9 mostra os resultados das médias, desvio padrão e porcentagem do desvio padrão relativo (\%RSD) das áreas individuais dos ácidos graxos, obtidos de dez injeções consecutivas da mistura padrão de ácidos graxos utilizando o ácido margárico como padrão interno.

A Tabela 10 mostra os cálculos efetuados dos resultados das médias, desvio padrão e (\%RSD) dos tempos individuais dos ácidos graxos, obtidos de dez injeções consecutivas da mistura padrão de ácidos graxos utilizando o ácido margárico como padrão interno. 
Tabela 9: Resultados das médias, desvio padrão e \%RSD para as áreas individuais dos ácidos graxos utilizando o padrão interno (C17).

\begin{tabular}{lccc}
\hline \hline \multicolumn{1}{c}{ Ácido graxo } & Média $^{*}$ & Desvio padrão* $^{*}$ & \%RSD* \\
\hline \hline Palmítico & 1,14 & 0,06 & 4,94 \\
Esteárico & 0,80 & 0,08 & 10,38 \\
Oléico & 1,18 & 0,14 & 11,55 \\
Linoléico & 1,00 & 0,13 & 12,95 \\
Linolênico & 1,49 & 0,15 & 9,86 \\
\hline \hline
\end{tabular}

*: média de dez determinações.

Tabela 10: Resultados das médias, desvio padrão e \%RSD para os tempos individuais dos ácidos graxos utilizando padrão interno (ácido margárico - C17:0)

\begin{tabular}{lccc}
\hline \hline \multicolumn{1}{c}{ Ácido graxo } & Média* $^{*}$ & Desvio padrão* $^{*}$ & $\%$ RSD $^{*}$ \\
\hline \hline Palmítico & 9,50 & 0,11 & 1,13 \\
Esteárico & 8,68 & 0,06 & 0,73 \\
Oléico & 9,23 & 0,11 & 1,21 \\
Linoléico & 9,81 & 0,13 & 1,33 \\
Linolênico & 10,35 & 0,13 & 1,27 \\
\hline \hline
\end{tabular}

*: média de dez determinações.

Durante a otimização do método por EC neste trabalho, deparou-se com alguns obstáculos quando se iniciou os experimentos relacionados ao processo de validação do método.

As áreas das injeções consecutivas apresentaram-se com variações em relação uma das outras. Em um primeiro momento, diante dos experimentos realizados relativos à etapa de linearidade, não foi possível obter um coeficiente de correlação satisfatório para a curva de calibração dos compostos estudados. Como conseqüência, a quantificação dos ácidos graxos pelo método desenvolvido não foi realizada. Este fenômeno pode ser observado na Figura 25, no qual mostra o eletroferograma de três injeções consecutivas da mistura padrão de ácidos graxos. 


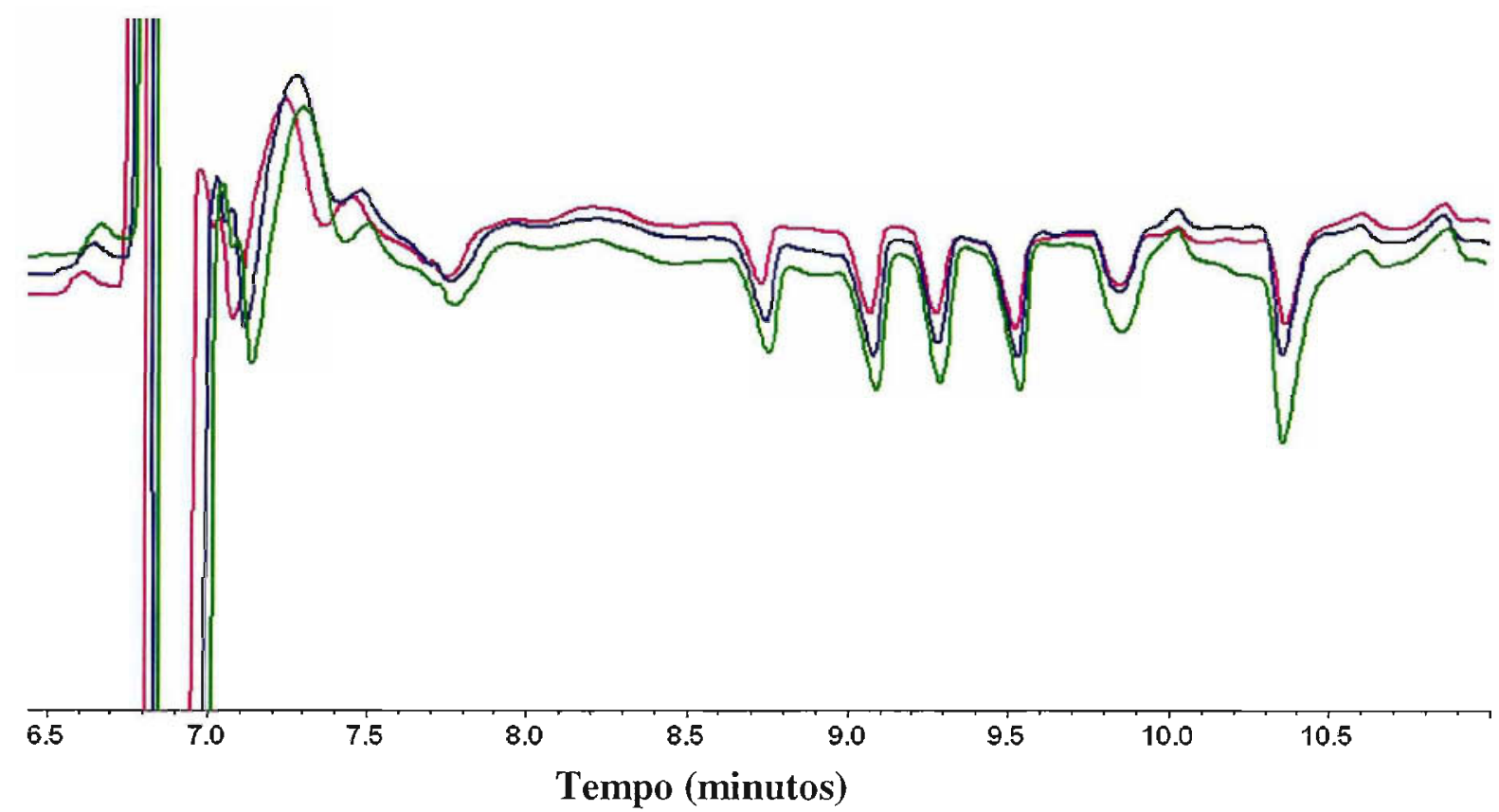

Figura 25: Eletroferograma de três injeções consecutivas de uma mistura padrão dos ácidos graxos na concentração de $0,25 \mathrm{mmol} \mathrm{L}^{-1}$ cada: (1) esteárico, (2) margárico, (3) oléico, (4) palmítico (5) linoléico e (6) linolênico, utilizando como eletrólito 12,5 mmol/L de tetraborato de sódio $\mathrm{pH} 7,0 ; 35 \%$ (v/v) ACN; $12,5 \mathrm{mmol} / \mathrm{L}$ Brij 35; 7,5 mmol/L SDBS. Capilar de $62 \mathrm{~cm}(50,2 \mathrm{~cm}$ até o detector) e $75 \mu \mathrm{m}$ de d.i. Voltagem aplicada: $+20 \mathrm{kV}$. Injeção hidrodinâmica 0,3 psi por $3 \mathrm{~s}, 25^{\circ} \mathrm{C}$ de temperatura.

A adsorção de solutos na parede interna do capilar é um problema que afeta intensamente o desempenho da separação de compostos em CE. As conseqüências diretas da adsorção de solutos é a redução da resolução devido ao alargamento da separação das bandas e repetibilidades das áreas dos picos e dos tempos de migração (Wätzig et al, 2003). A adsorção freqüentemente aumenta após certo número de sucessivas injeções e pode estar relacionada com a composição do eletrólito, os efeitos da matriz da amostra ou as características estruturais do analito. Por esta razão, as lavagens do capilar pós-condicionamento e entre as injeções são frequentemente recomendadas. Quando esses procedimentos não conseguem restabelecer a condição original do capilar, a vida útil deste pode ser encurtada e a utilização da metodologia para aplicações de rotina pode se tornar impraticável. Em alguns casos, este fenômeno pode ser de irreversível adsorção, uma vez que é impossível reproduzir o mesmo perfil de separação da primeira injeção. 
Oliveira e colaboradores propuseram um método de determinação dos ácidos graxos de cadeia longa do óleo de oliva por eletroforese capilar utilizando como eletrólito $15 \mathrm{mmol} \mathrm{L}^{-1}$ tampão fosfato $\mathrm{pH} 6.86,4 \mathrm{mmol} \mathrm{L}^{-1} \mathrm{SDBS}, 10 \mathrm{mmol} \mathrm{L}^{-1}$ Brij 35 , $45 \% \mathrm{v} / \mathrm{v}$ ACN e $2 \% \mathrm{v} / \mathrm{v}$ 1-octanol (OLIVEIRA et al., 2007). Os autores observaram que após sete injeções consecutivas de uma mistura padrão de ácidos graxos, os perfis dos electroferogramas foram alterados por um alargamento das bandas de separação, uma lenta mudança do tempo de migração e um aumento significativo na corrente. A fim de investigar as possíveis causas desse fenômeno, um segmento de aproximadamente $10 \mathrm{~cm}$ de um capilar novo foi imerso em uma solução contendo o eletrólito durante uma semana. Depois deste período, o segmento do capilar submerso foi observado sob um microscópio ótico e uma degradação parcial do revestimento externo do capilar, poliimida, foi observada. Os autores constataram que o revestimento foi parcialmente dissolvido no eletrólito e este fato possivelmente acarretou na aderência gradual do polímero à parede interna capilar, perturbando o perfil de separação de forma significativa.

Uma solução proposta pelos autores foi a retirada de poliimida de aproximadamente $1,5 \mathrm{~cm}$ do extremo do capilar que fica em contato com o eletrólito (dentro do vial de entrada) (OLIVEIRA et al, 2007). Esta proposta foi realizada no presente trabalho, porém houve uma diminuição da vida útil do capilar, uma vez que este apresentou-se mais frágil. Isso dificulta e acarreta em um maior tempo para conseguir resultados satisfatórios que levem a validação do método em questão.

Deve-se atentar também para o modelo e a marca do equipamento de eletroforese capilar. Alguns modelos, os extremos do capilar se encontram no interior do eletrodo (como é o caso do equipamento de EC da marca Agilent) o que diminui um pouco o contato direto com o eletrólito. Isso tornaria mais duradoura a vida útil do capilar e, portanto viabilizaria melhor os resultados de reprodutibilidade.

Acredita-se que a baixa repetibilidade de área (4,9-12,95\% RSD), mostrada na Tabela 9 nas determinações da mistura padrão de ácidos graxos pelo método otimizado é devido à adsorção da poliimida na parede interna do capilar. Segundo Collet \& Gareil, o uso de Brij 35 em eletrólito proporciona um acúmulo deste composto na parede interna do capilar, devido a interações por pontes de hidrogênio com os grupos silanóis do capilar. Um dos obstáculos enfrentados neste trabalho foi 
a pequena vida útil do capilar e a constante queda de corrente, que pode ser justificado pela adição do Brij 35 no eletrólito. Verificou-se, portanto, que ao se utilizar metanol entre as corridas houve uma melhora significativa nos problemas acima mencionados.

Portanto, deve se ter em mente, que antes de propor um método efetivamente validado para ácidos graxos utilizando alta quantidade de solvente orgânico, uso de aditivos que possam viabilizar a fragilidade do método há de se garantir soluções para contornar esses tipos de problemas.

A existência recente de capilares próprios para eletrólitos que contém solventes orgânicos em sua composição surge como uma alternativa para perspectivas futuras na complementação do trabalho em questão, como por exemplo, a validação do método aqui desenvolvido.

\subsection{Estudo de estabilidade das formulações cosméticas}

\subsubsection{Teste de estabilidade preliminar}

As amostras das formulações F1A e F2A foram submetidas ao teste de centrifugação a $3.000 \mathrm{rpm}$ durante 30 minutos antes de iniciar os Estudos de Estabilidade. O produto permaneceu estável, sem sinais de separação de fases (Figura 26).

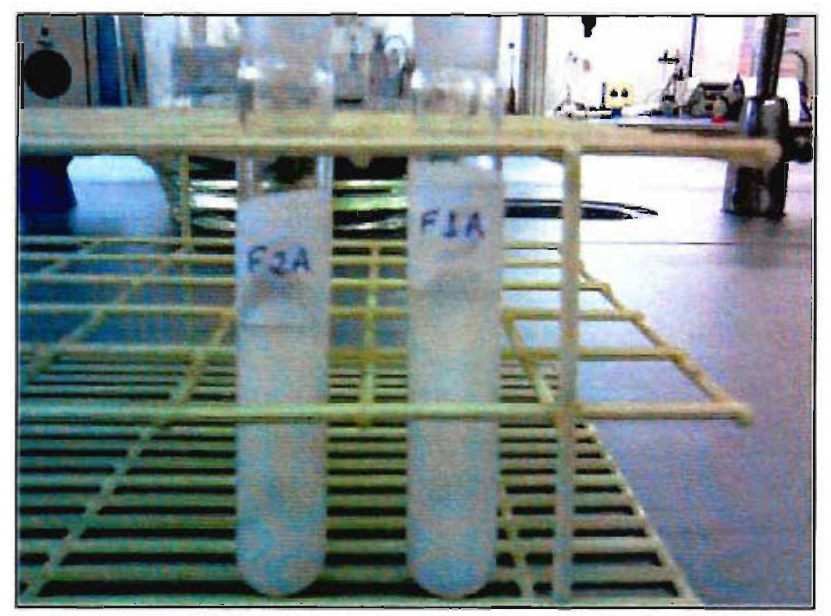

Figura 26: Formulações após o teste de estabilidade preliminar (centrifugação a 3000 rpm durante 30 minutos). 
As amostras das formulações desenvolvidas são do tipo de emulsão: O/A (solúvel em água, formação de fase homogênea sem grumos).

\subsubsection{Teste de estabilidade acelerada}

Os resultados do Estudo de Estabilidade Acelerada estão descritos na Tabelas 11 e 12. De acordo com os resultados do estudo de estabilidade, observouse que as formulações mantiveram suas características físicas e organolépticas, valores de $\mathrm{pH}$ e de viscosidade aparente sem alterações significativas, mesmo em condições de temperatura elevada, 6 ciclos de congelamento na geladeira e descongelamento na estufa, sendo possível afirmar que as formulações desenvolvidas foram estáveis, pelo período de 90 dias, nas condições estabelecidas (Figura 27).

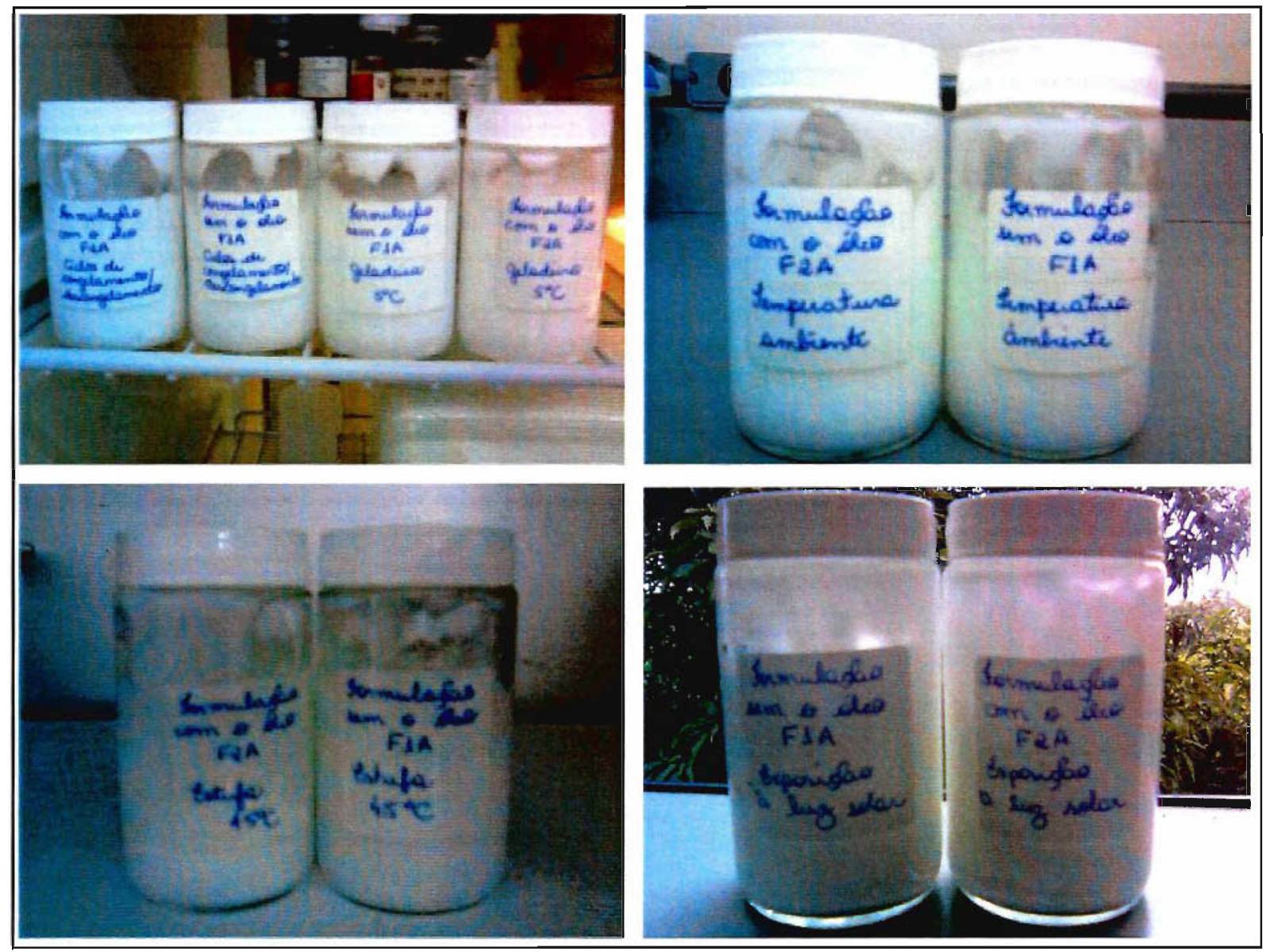

Figura 27: Formulações no teste de estabilidade acelerada (Ciclos de congelamento $5^{\circ} \mathrm{C} /$ descongelamento $45^{\circ} \mathrm{C}$, geladeira à $5^{\circ} \mathrm{C}$, temperatura ambiente, estufa à $45^{\circ} \mathrm{C} \mathrm{e}$ radiação solar). 
De acordo com recomendações do Guia de estabilidade de Produtos Cosméticos da ANVISA, o período de avaliação dos testes de estabilidade normal é de 90 dias (ANIVISA, 2004).

As Figuras 28, 29, 30 e 31 mostram as variações percentuais do $\mathrm{pH}$ e da viscosidade da formulação base e da formulação associada ao óleo de Castanha do Brasil.

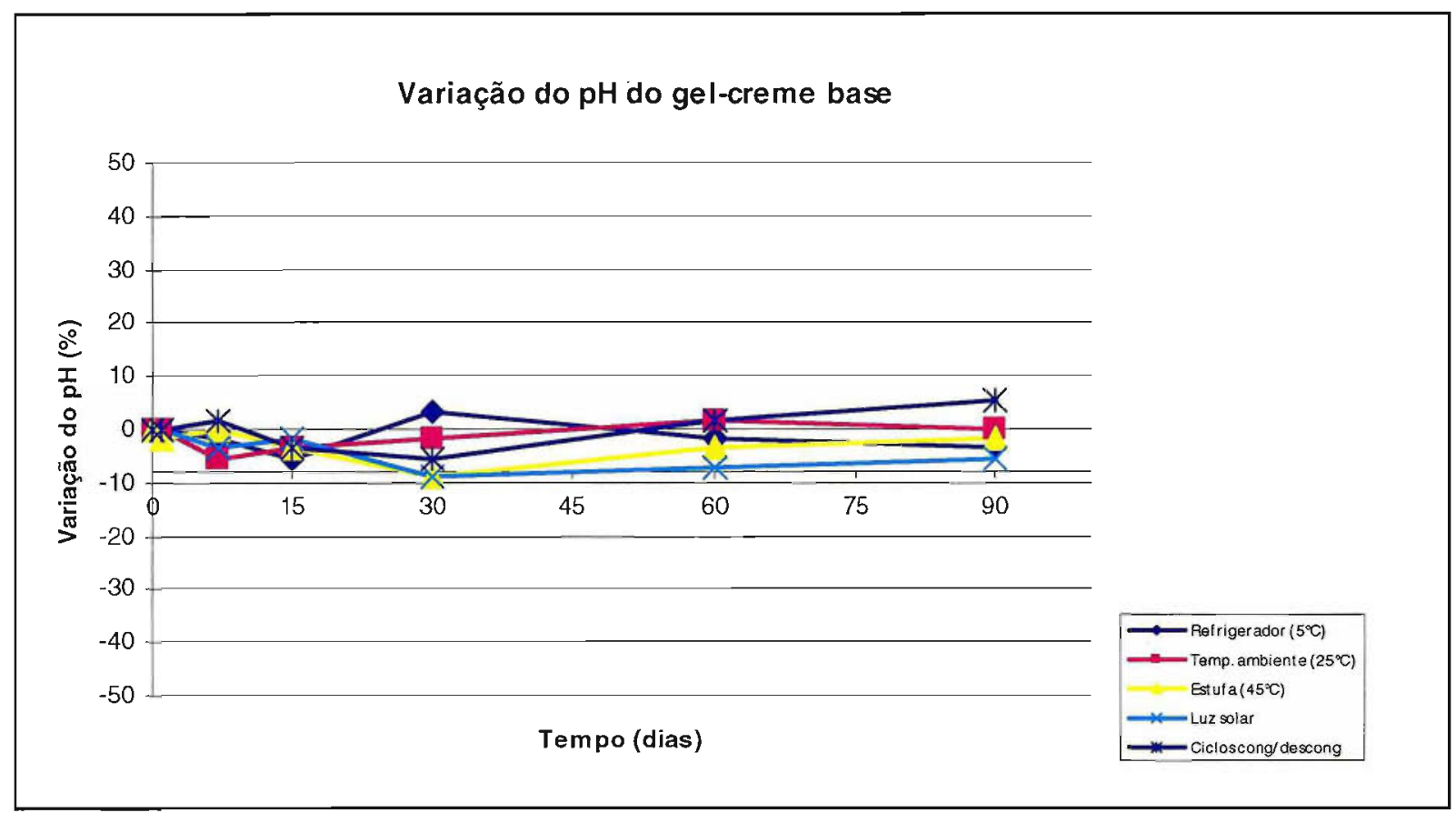

Figura 28: Variação percentual do valor de $\mathrm{pH}$ do gel-creme base

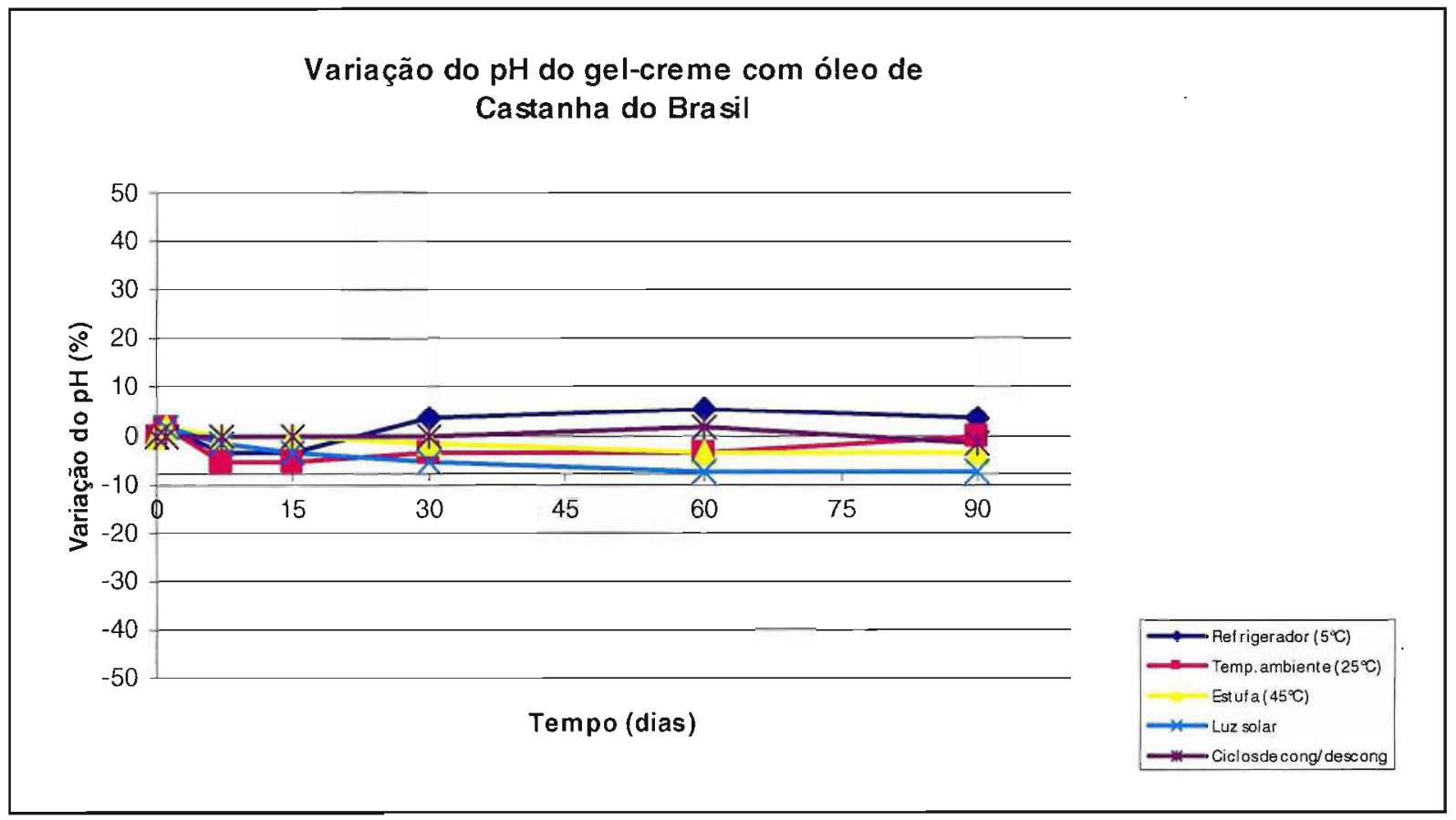

Figura 29: Variação percentual do valor de $\mathrm{pH}$ do gel-creme contendo o óleo de Castanha do Brasil 
Variação da viscosidade do gel-creme base

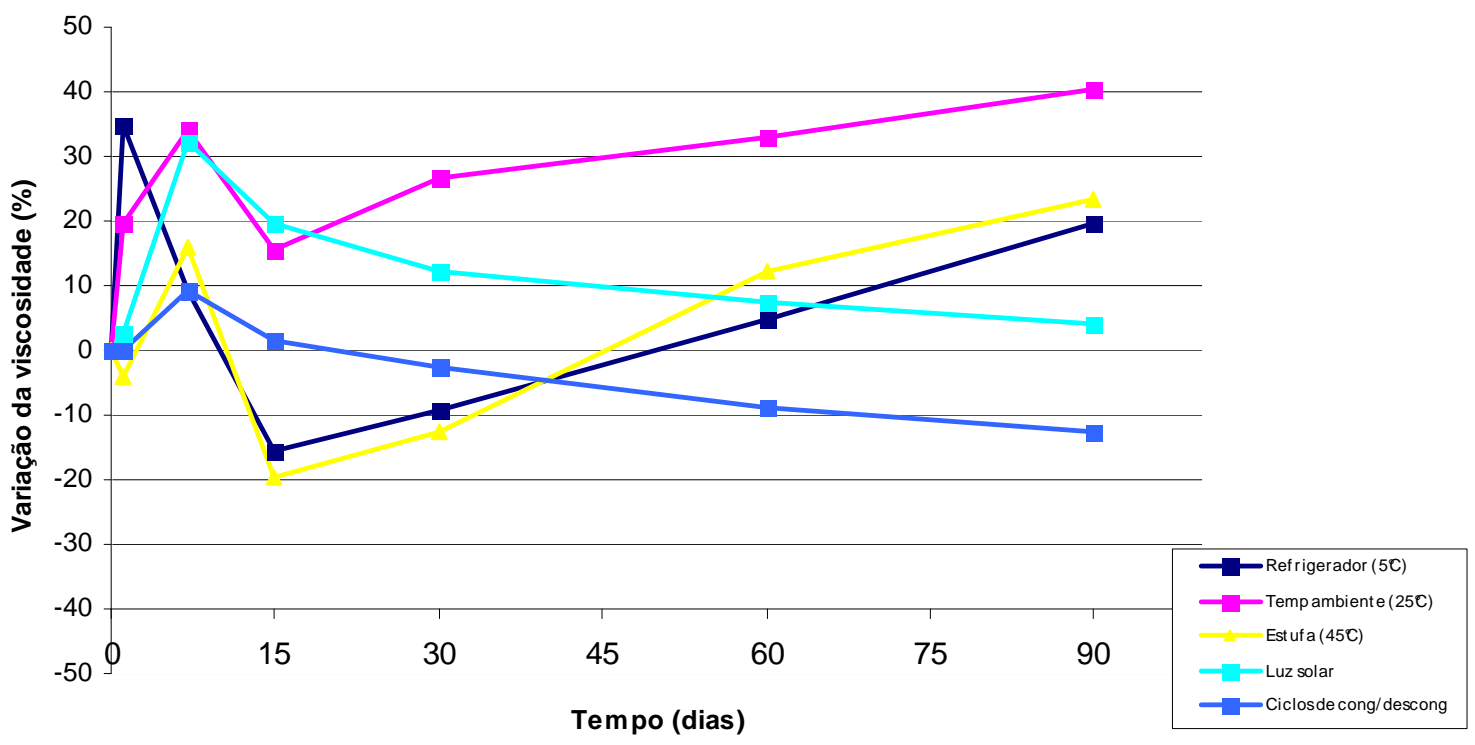

Figura 30: Variação percentual do valor de viscosidade aparente do gel-creme base

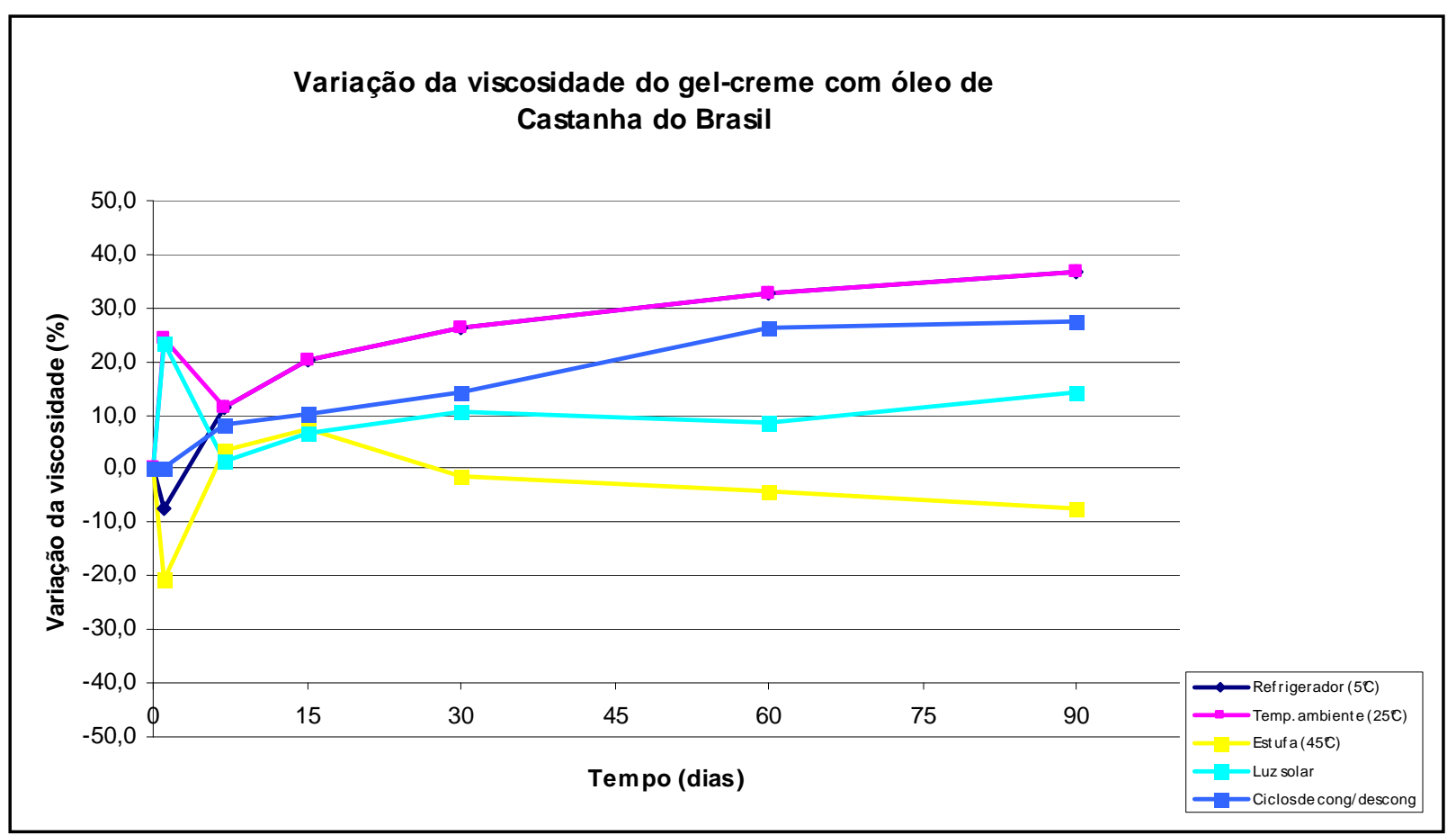

Figura 31: Variação percentual do valor de viscosidade aparente do gel-creme contendo o óleo de Castanha do Brasil 


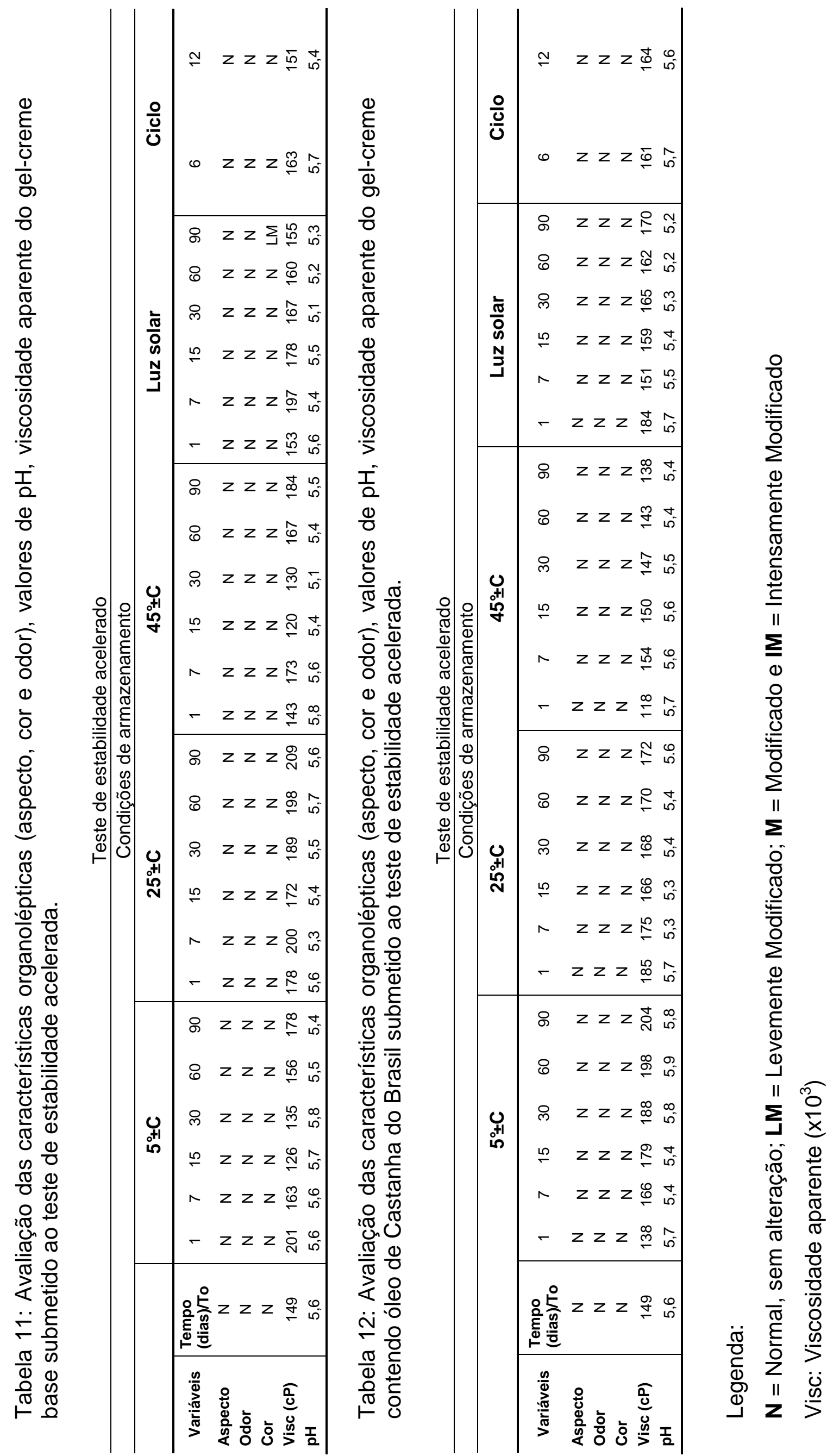




\subsection{Análise térmica}

\subsection{1. Óleo de Castanha do Brasil}

As curvas TG/DTG apresentadas na Figura 30 representam o comportamento térmico da amostra de óleo de Castanha do Brasil.

As curvas TG/DTG deste óleo mostraram um patamar de estabilidade térmica até aproximadamente $220^{\circ} \mathrm{C}$ e evidenciaram o processo de decomposição térmica que ocorreu em quatro etapas, com $\mathrm{T}_{\text {pico }}$ em 330, 370, 440 e $540^{\circ} \mathrm{C}$. As perdas de massa se completa em $580^{\circ} \mathrm{C}$, indicando $3 \%$ de resíduo, que corresponde ao teor de material inorgânico ou sais minerais. Este óleo apresenta tipicamente em sua composição ácidos graxos saturados e insaturados como: palmítico (C16:0), esteárico (C18:0), oléico (C18:1), linoléico (C18:2), e em menores concentrações, linolênico (C18:3), araquídico (C20:0) e outros. A curva DSC evidenciou dois eventos exotérmicos bem definidos, característicos da decomposição térmica do material com $\mathrm{T}_{\text {pico }}$ em $350^{\circ} \mathrm{C}$ e $440^{\circ} \mathrm{C}$ e que estão em concordância com a s perdas de massa observadas nas curvas TG/DTG.

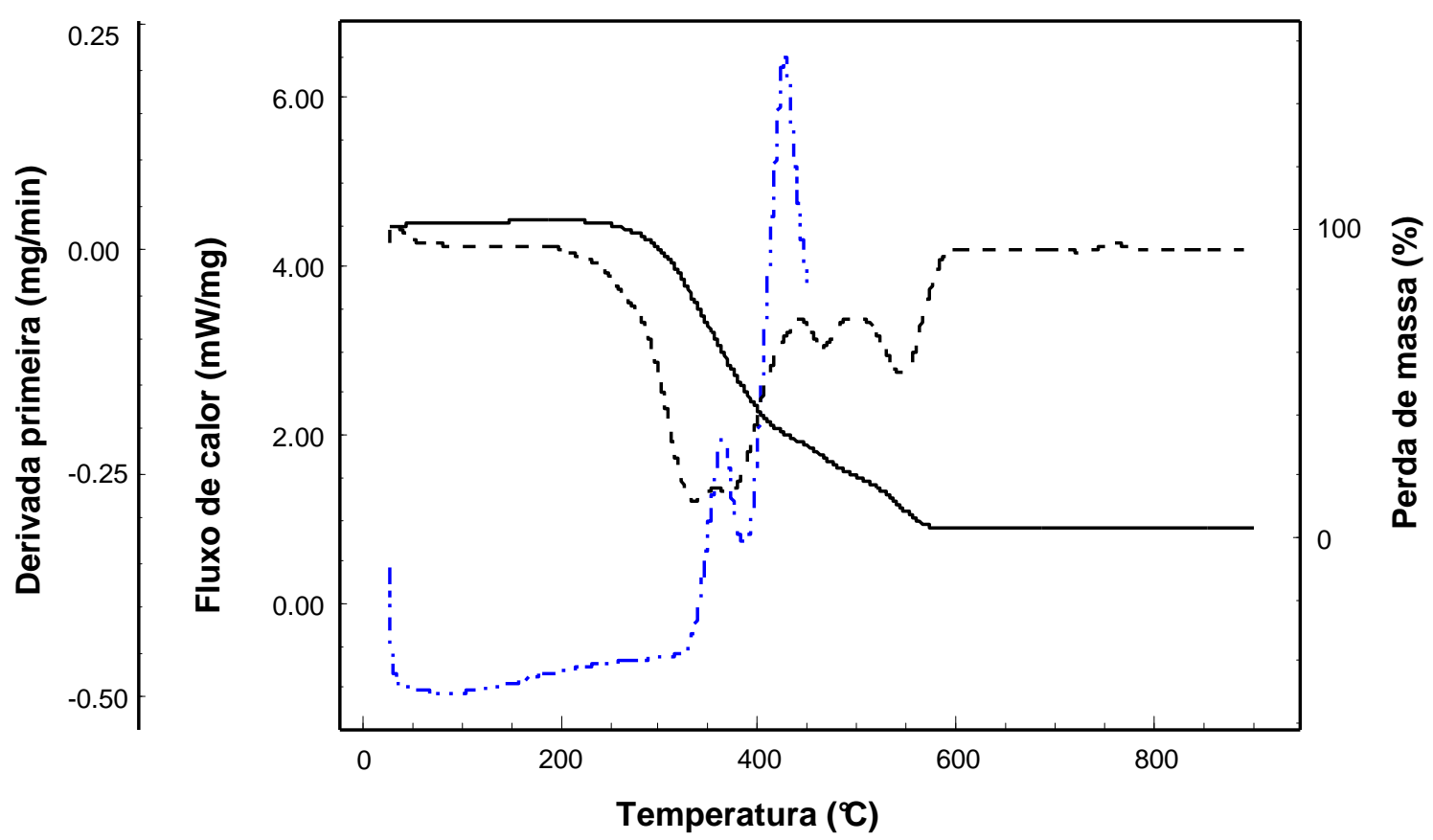

Figura 32: Curvas TG/DTG e DSC do óleo de Castanha do Brasil obtidas a $10^{\circ} \mathrm{C}$ $\min ^{-1}$, sob atmosfera dinâmica de ar sintético (TG/DTG) e $\mathrm{N}_{2}$ (DSC). 


\subsubsection{Formulações cosméticas}

As curvas TG/DTG apresentadas na Figura 31 representam o comportamento térmico das amostras das formulações F1A (Formulação sem o óleo de Castanha do Brasil) e F2A (com o óleo de Castanha do Brasil).

As curvas TG/DTG evidenciaram que em ambos os casos são observados duas etapas distintas de perda de massa. A primeira referente a eliminação da água e a segunda, devido a decomposição térmica dos outros componentes da formulação.

A curva TG/DTG referente à amostra F2A evidenciou um deslocamento do processo de perda de massa para temperatura mais elevada ( $T$ pico da amostra $F 1 A$ corresponde a $125^{\circ} \mathrm{C}$ e amostra F2A à $132^{\circ} \mathrm{C}$ ). Esse re sultado indica uma maior estabilidade da matriz contendo o óleo. Comparando com a curva referente à amostra F1A, pode-se então concluir que essa diferença na perda de massa está relacionada a presença do óleo de Castanha do Brasil.

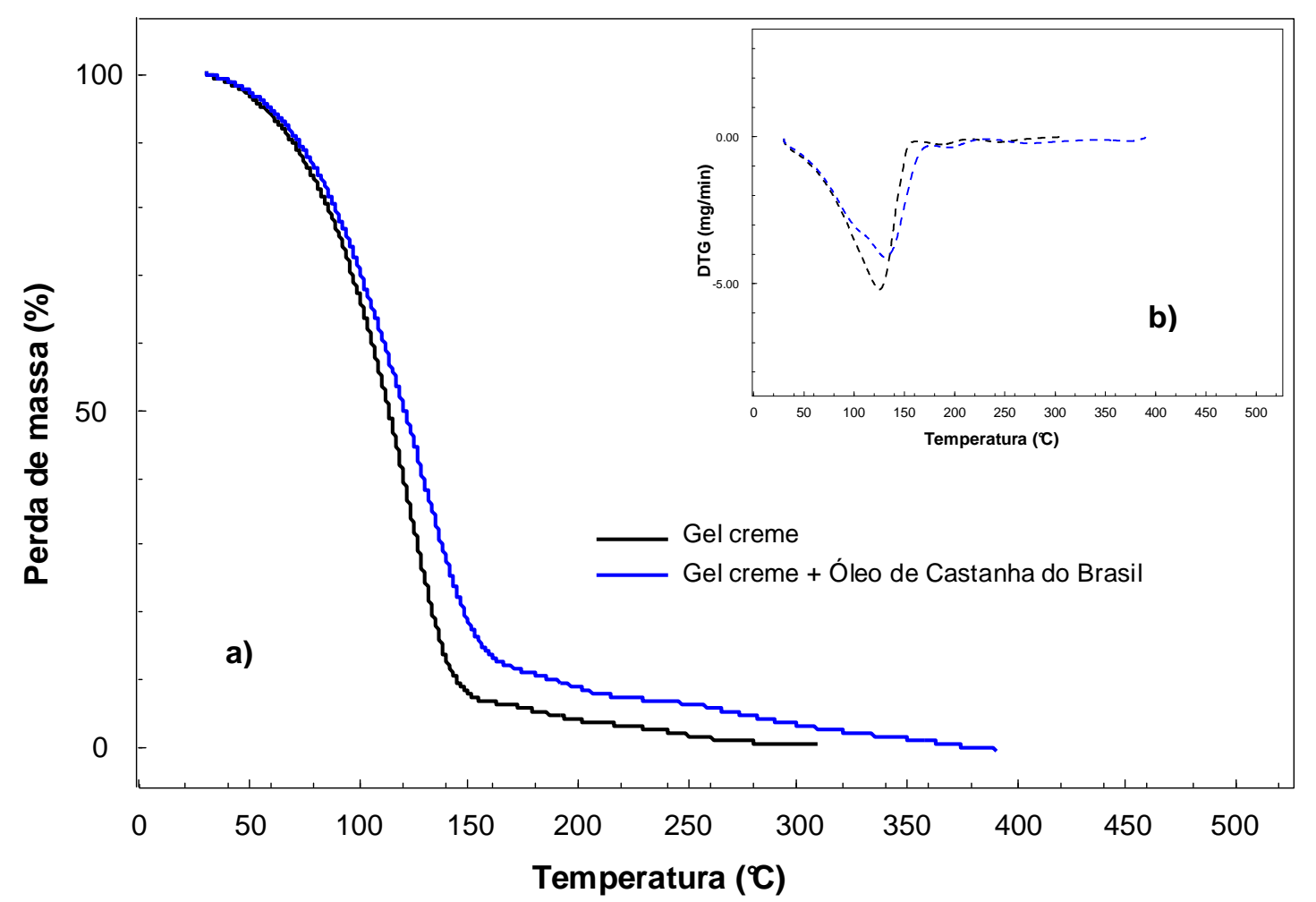

Figura 33: Curvas a) TG e b) DTG do gel-creme e do gel-creme associado ao óleo de Castanha do Brasil obtidas a $10^{\circ} \mathrm{C} \cdot \mathrm{min}^{-1}$, sob atmosfera dinâmica de ar sintético. 
O percentual total de perda de massa para a amostra F1A foi de $97 \%$, enquanto que para a amostra F2A foi de $92 \%$ (que foi adicionado à formulação em $5 \%$ ). Pode-se inferir que, essa diferença corresponde ao teor do óleo presente no gel-creme.

5.5.3. Estudo cinético do óleo de Castanha do Brasil por termogravimetria pelo método isotérmico

A Figura 34 mostra as isotermas utilizadas na determinação da energia de ativação $\left(E_{a}\right)$ do óleo de Castanha do Brasil. Esta foi realizada utilizando-se os dados referentes ao tempo necessário para que houvesse uma perda de massa mínima de 5 e 10\% em faixas de temperatura superior a $200^{\circ} \mathrm{C}$, próximas ao início de sua decomposição térmica. Estes dados possibilitaram a construção de um gráfico de Arrhenius de InK vs 1/T e a determinação da equação da reta. A Figura 35 apresenta o gráfico de regressão linear da perda de massa relacionando tempo $(\mathrm{t}) \mathrm{e}$ temperatura (T). A inclinação da reta é definida pelo coeficiente angular (a), onde a energia de ativação pode ser definida multiplicando-se (a) pela constante geral dos gases $R\left(8,314 \mathrm{~J} \mathrm{~mol}^{-1} \mathrm{~K}^{-1}\right)$. A regressão linear calculada para os dados cinéticos do óleo de Castanha do Brasil origina uma equação (1), com coeficiente de correlação linear de 0,9942 $\left(r^{2}\right)$. A energia de ativação calculada para o óleo de Castanha do Brasil foi de 75,91 $\mathrm{KJ} \mathrm{mol}^{-1}$. Calculou-se a estabilidade (em anos) do óleo de Castanha do Brasil com base na equação (1), utilizando $25{ }^{\circ} \mathrm{C}$ como padrão de temperatura ambiente. $O$ resultado foi um tempo estimado de estabilidade térmica de aproximadamente 30 anos a partir da data da análise. 


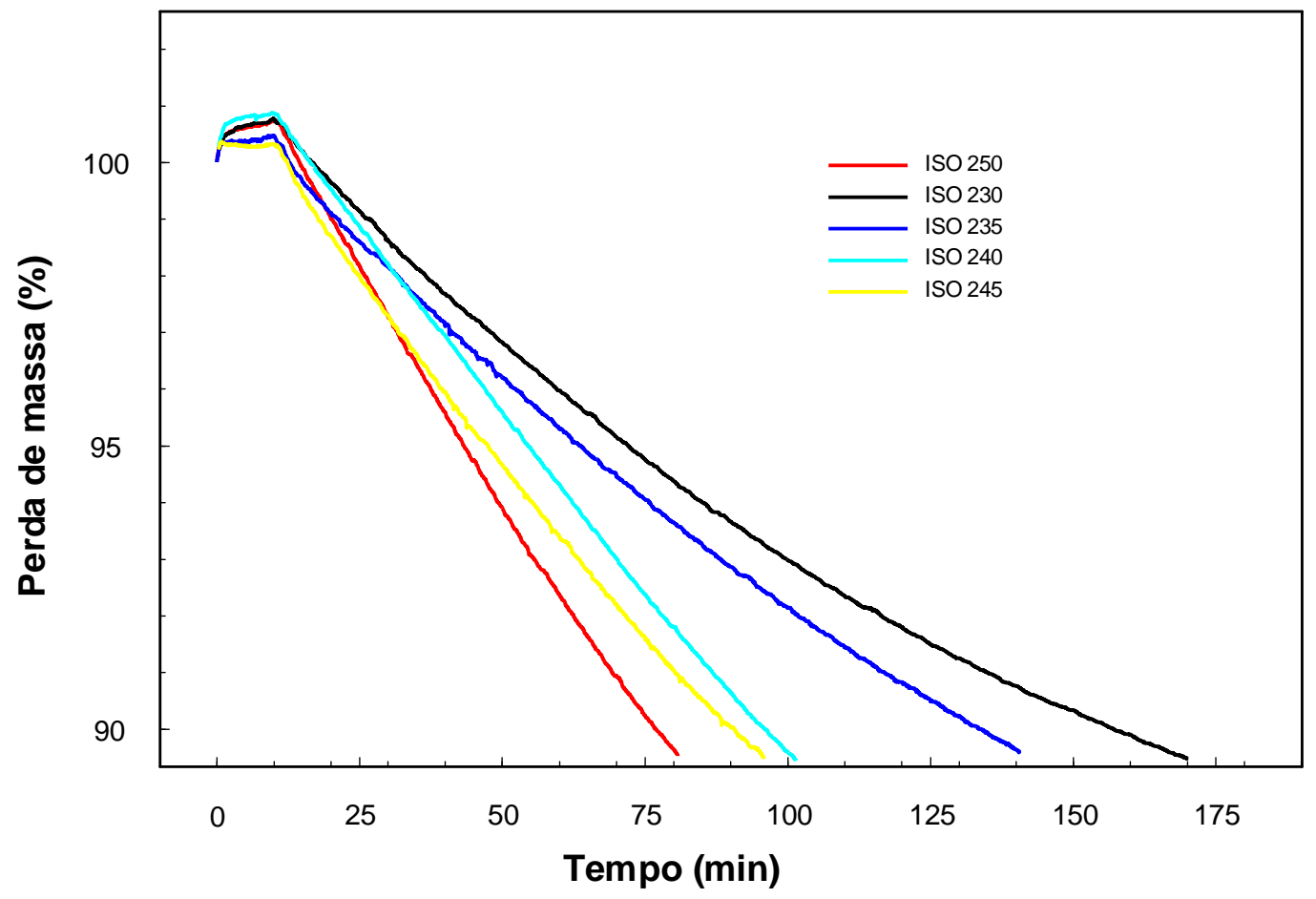

Figura 34: Curvas TG do óleo de Castanha do Brasil a diferentes isotermas de temperaturas em atmosfera de ar

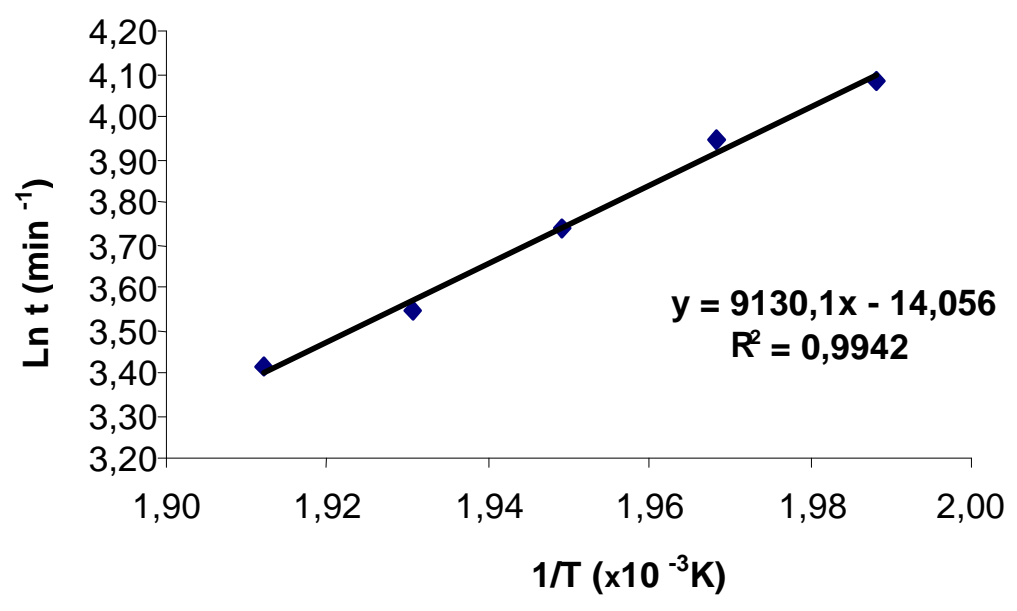

Figura 35: Gráfico InK ( $\left.\min ^{-1}\right)$ VS. 1/T $\left(\mathrm{K}^{-1}\right)$ e a equação da reta. 


\section{CONCLUSÕES}

$\checkmark$ A eletroforese capilar mostrou ser uma ferramenta útil para identificação dos ácidos graxos do óleo de Castanha do Brasil, apresentando vantagens em relação a outros métodos comumente utilizados. As principais vantagens desse método são as seguintes: o reduzido tempo, baixo custo de análise e o baixo consumo de solventes, o que minimiza os custos com tratamento de resíduos e impacto ambiental.

$\checkmark$ A análise térmica pode ser utilizada como ferramenta de caracterização química de um dado componente, podendo ser incluída como item de análise em sua especificação.

$\checkmark$ A estabilidade térmica dos componentes de uma formulação pode auxiliar no controle de parâmetros de processos industriais de fabricação.

$\checkmark \quad$ O estudo cinético pode ser aplicado como metodologia rápida para a predição do prazo de validade do óleo de Castanha do Brasil.

$\checkmark$ O estudo cinético por TG não objetiva a substituição ou a isenção dos estudos de estabilidade comumente realizados, porém possui vantagens relacionadas à simplicidade e rapidez. Desta maneira a utilização da análise térmica vem a ser uma alternativa de interesse na área de controle de qualidade.

$\checkmark \quad \mathrm{O}$ estudo de estabilidade das formulações demonstrou que estas se mantiveram estáveis pelo período de 90 dias, não apresentando significativas alterações entre as formulações contendo o óleo e a formulação base. Estes fatos ressaltam a utilização do óleo de Castanha do Brasil em produtos para o consumo cosmético. 


\section{PERSPECTIVAS}

O presente trabalho permitiu ter uma idéia de como a eletroforese capilar pode ser utilizada em controle de qualidade de cosméticos.

Uma vez validado o método em questão, este pode ser utilizado para verificação da presença ou não de ácidos graxos em amostras reais. Isso implica na identificação de ácidos graxos proveniente de várias fontes, como por exemplo:

- Óleos vegetais utilizados como matérias-primas emolientes em produtos cosméticos

- Óleos vegetais incorporados à formulações, nos quais as indústrias muito utilizam como apelo natural para comercialização de seus produtos

Tendo em vista do exposto, fica claro, portanto a importância do método desenvolvido e a continuidade deste para uma futura aplicabilidade em vários setores da indústria cosmética. 


\section{REFERÊNCIAS BIBLIOGRÁFICAS}

ALTRIA, K.D. Capillary electrophoresis guidebook: principles, operation, and applications. Totowa: Humana Press, 1996. 349p. (Methods in molecular biology, v.52).

ALTRIA, K.D. Overview of capillary electrophoresis and capillary electrochromatography. Journal of Chromatography, A, v.856, p.443-463, 1999.

ALTRIA, K.D.; BRODERICK, M.F.; DONEGAN, S.; POWER, J. The use of novel water-in-oil microemulsions in microemulsion electrokinetic chromatography. Electrophoresis, v.25, n.4/5, p.645-652, 2004.

ALTRIA, K.D.; ELDER, D. Overview of the status and applications of capillary electrophoresis to the analysis of small molecules. Journal of Chromatography, A, v.1023, p.1-4, 2004.

ANDRADE, J.C.; CUSTODIO, R. Eletroforese capilar. Disponível em: http://www.chemkeys.com/bra/md/mds 11/mds 11.htm. Acesso em: 12 jul. 2005.

ANASTOS, N.; BARNETT, N.W.; LEWIS, S.W. Capillary electrophoresis for forensic drug analysis: a review. Talanta, v.67, p.269-279, 2005.

AGÊNCIA NACIONAL DE VIGILÂNCIA SANITÁRIA. Guia de estabilidade de produtos cosméticos. Brasília: ANVISA, 2004. 47p. (Séries temáticas da Anvisa. Qualidade em cosméticos; 1).

BABY, A.R.; MACIEL, C.P.M.; SALGADO-SANTOS, I.M.N.; DIAS, T.C.S.; KANEKO, T.M.; CONSIGLIERI, V.O.; VELASCO, M.V.R. Uso de extratos de plantas em produtos cosméticos. Cosmetics \& Toiletries, Edição em Português, v.17, p.7882, 2005.

BAKER, D.R. Capillary electrophoresis. New York: John Wiley, 1995. 244p. (Techniques in analytical chemistry series).

BANNORE, Y.C.; CHENAULT, K.D.; MELOUK, H.A.; RASSI, Z.E. Capillary electrophoresis of some free fatty acids using partially aqueous electrolyte systems and indirect UV detection: application to the analysis of oleic and linoleic acids in peanut breeding lines. Journal of Separation Science, v.31, 2667-2676, 2008.

BLIGH, E.G.; DYER, W.J. A rapid method of total lipid extraction and purification. Canadian Journal of Biochemistry and Physiology, v.37, p.911-917, 1959.

BROWN, M.E. Introduction to thermal analysis: tecniques and applications. London: Chapman and Hall, 1988. p.1.

BUCHBERGER, W.; WINNA, K. Determination of free fatty acids by capillary zone electrophoresis. Mikrochimica Acta, v.122, n.1/2, p.45-52, 1996. 
CALDER, P.C. Long-chain n-3 fatty acids and inflammation: potential application in surgical and trauma patients. Brazilian Journal of Medical and Biological Research, 36, n.4, p.433-446, 2003.

CAMMEGA, H.K.; EPPLE, M. Basic principle of thermoanalyticasl techniques and their applications in preparative chemistry. Angewandte Chemie International Edition, v.34, n.11, p.1171-1187, 1995.

CAMPOS, V.M.C. Extração do óleo da castanha-do-pará. Fundação Centro Tecnológico de Minas Gerais - CETEC, 2007.

CANDIDO, L.C. Nova abordagem no tratamento de feridas. São Paulo: SENAC, 2001. 288p.

CARDOSO, C.R.B.; SOUZA, M.A.; FERRO, E.A.V.; FAVORETO, S.; PENA, J.D.O. Influence of topical administration of $n-3$ and $n-6$ essential and $n-9$ nonessential fatty acids on the healing of cutaneous wounds. Wound Repair and Regeneration, v.12, n.2, p.235-243, 2004.

CARVALHO, R.A.; FERREIRA, C.A.P.; HOMMA, A.K.O. Fontes de crescimento das exportações de Castanha-do-Brasil (1970-1988). Belém: EMBRAPA-CPATU, 1994. 27p. (EMBRAPA-CPATU. Documentos, 76).

CASTRO, H.F.; MENDES, A.A.; SANTOS, J.C.; AGUIAR, C.L. Modificações em óleos e gorduras por biotransformação. Química Nova, v.27, n.1, p.146-156, 2004.

COCITO, C.; DELFINI, C. Simultaneous determination by GC of free and combined fattyacids and sterols in grape musts and yeasts as silanized compounds Food Chemistry, v.50, n.3, p.297-305, 1994.

COLZATO, M.; FORATO, L.A.; COLNAGO, L.A.; ASSIS, O.B.G. Análise comparativa dos espectros de ${ }^{1} \mathrm{H}$ RMN de óleos comestíveis oxidados. São Carlos: EMBRAPA, 2008. [Comunicado técnico, 92].

CUNHA, A.P.; SILVA, A.P.; ROQUE, O.R.; CUNHA, E. Plantas e produtos vegetais em cosmética e dermatologia. Lisboa: Fundação Calouste Gulbenkian, 2004.

CUNHA, E.S.M.; DANTAS, F.L.C.G. O que você precisa saber sobre a castanhado-Brasil: de informações técnicas a curiosidades. Macapá: Secretaria de Estado de Meio Ambiente, Ciência e Tecnologia (Sema), 1997.

CURI, R.; MIYASAKA, C.K.; PROCÓPIO, J. Entendendo a gordura: os ácidos graxos. São Paulo: Manole, 2002.

DECLAIR, V. Uso de triglicérides de cadeia média na prevenção de úlceras de decúbito. Revista Brasileira de Enfermagem, v.47, n.2, p.127-130, 1994.

DRANGE, E.; LUNDANES, E. Determination of long-chained fatty acids using nonaqueous capillary electrophoresis and indirect UV detection. Journal of Chromatography, A, v.771, n.1/2, p.301-309, 1997. 
DURST, H.D.; MILANO, M.; KIKTA, E.J.; CONNELLY, S.A.; GRUSHKA, E. Phenacyl esters of fatty-acids via crown ether catalysts for enhanced ultraviolet detection in liquid-chromatography. Analytical Chemistry, v.47, n.11, p.1797-1801, 1975.

DRAELOS, Z.K. Cosméticos em dermatologia. 2.ed. Rio de Janeiro: Revinter, 245p. 1999.

ECCLESTON, G.M. Emulsions and microemulsions. In: SWARBRICK, J.; BOYLAN, J.C. Encyclopedia of pharmaceutical technology. New York: Marcel Dekker, 2002. v.3, p.1066-1084.

ELIAS, L.G.; BRESSANI, R. The nutritive value of Brazil nut oil. Journal of the American Oil Chemists' Society, v.38,450p. 1961.

ERIM, F.B.; XU, X.; KRAAK, J.C. Application of micellar electrokinetic chromatography and indirect UV detection for the analysis of fatty-acids. Journal of Chromatography, A, v.694, n.2, p.471-479, 1995.

ERMER, J. Validation in pharmaceutical analysis. Part I. An integrated approach. Journal of Pharmaceutical and Biomedical Analysis, v.24, p.755-767, 2001.

EVANS, W.J. Vitamin E, vitamin C and exersice. American Journal of Clinical Nutrition, v.72, n.2, suppl., p.647S-652S, 2000. Disponível em: www.science.com.br/henrys corner/artigos tecnicos/novos/vitamin C andexercise. pdf. Acesso em: 12/10/2006.

FERREIRA, E.J.L.; NASCIMENTO, J.F.N.; LIMA, A.C.; SILVA, C.R.; OLIVEIRA, E.S. Óleos de plantas nativas da Amazônia: Parte 1. Disponível em: www.ambienteacreano.blogspot.com/2005 1101 archive.html. Acesso em: 20/11/2008.

FLORENCE, A.T.; ATTWOOD, D. Princípios físico químicos em farmácia. São Paulo: USP, 2003. p.345-375, 413-455.

FUJIMORI, Y.; MATOS, J.R.; KEDOR-HACKAMANN, E.R.M. Utilização de análise térmica na determinação quantitativa de água fixa interlamelar e água dispersa em creme O/A. In: SEMINÁRIO DA PÓS-GRADUAÇÃO DA FACULDADE DE CIÊNCIAS FARMACÊUTICAS DA USP, 8, São Paulo, 1993. Resumos. São Paulo: Coordenadoria De Comunicação Social/USP, 1993. 90p.

GALLAHER, D.L.; JOHNSON, M.E. Nonaqueous capillary electrophoresis of fatty acids derivatized with a near-infrared fluorophore. Analitical Chemistry, v.72, n.9, p.2080-2086, 2000.

GARCIA, C.R.C. Atualização em princípios ativos antienvelhecimento. Revista de Cosmiatria Méd Estética, v.4, n.4, p.9-20, 1996.

GARCIA, S. Lipossomas com filtro solar: preparação e controle de qualidade. São Paulo, 1998. 161p. (Tese de Doutorado - Faculdade de Ciências Farmacêuticas Universidade de São Paulo).

GENTRY, A.H. A field guide to the families and genera of woody plants of Northwest South America (Colômbia, Ecuador, Peru). Chicago: University of Chicago Press, P. 497, 1996. 
CHANG, C.C.; GUTENMANN, W.H.; REID, C.M.; LISK, D.J. Selenium content of Brazil nuts from two geographic locations in Brazil. Chemosphere, v.30, n.4, p.801802, 1995.

GIOLITO, I. Desenvolvimento, classificação e aplicações dos métodos termoanalíticos. Revista Química Industrial, n.663, p.12-20, 1988.

GIOLITO, I.; IONASHIRO, M. A nomenclatura em análise térmica parte II. Cerâmica, v.34, n.225, p.163-164, 1988.

GOKEL, G.W.; DURST, H.D. Principles and synthetic applications in crown ether chemistry. Synthesis, v.3, p.168-184, 1976.

GOMES DA SILVA, W.; CORTESI, N.; ROVELLINI, P. La nocciola brasiliana (Bertholletia excelsa H.B.K., famiglia delle Lecythidaceae). Nota II. I Lipidi-Studi sulla composizioni chimica. Rivi. Ital. Sostanze Grasse, v.74, p.311-314, 1997.

GRIMBLE, R.F.; TAPPIA, P.S. Modulation of pro-inflammatory cytokine biology by unsaturated fatty acids. Z. Ernahrungswiss, v.37, suppl.1, p.57-65, 1998.

GUNSTONE, F.D.; NORRIS, F.A. Lipids in foods: chemistry, biochemistry and technology. Oxford: Pergamon Press,170p. 1983.

GURR, M.I.; HARWOOD, J.L. Lipid biochemistry: an introduction. 4.ed. London: Chapman \& Hall, p.162-243,1996.

GUTIERREZ, E.M.R.; REGITANO-D'ARCE, M.A.S.; RAUEN-MIGUEL, A.M.O. Estabilidade oxidativa do óleo bruto a castanha-do-Pará (Bertholletia excelsa). Ciência e Tecnologia de Alimentos, v.17, n.1, p.22-27, 1997.

GUTNIKOV, G.; BECK, W.; ENGELHARDT, H. Separation of homologous fatty-acids by capillary electrophoresis. Journal Of Microcolumn Separations, v.6, n.6, p.565570, 1994.

HADDADIAN, F.; SHAMSI, S.A.; WARNER, I.M. Separation of saturated and unsaturated free fatty acids using capillary electrophoresis with indirect photometric detection. Journal of Chromatographic Science, v.37, n.4, p.103-107, 1999.

HAINES, P.J. Thermal methods of analysis: principles, applications and problems. London: Blackie Academic \& Professional, 286p. 1995.

HATANAKA, E.; LEVADA PIRES, A.; PITHON CURI, T.; CURI, R. Systematic study on ROS production induced by oleic, linoleic, and gamma-linolenic acids in human and rat neutrophils. Free Radical Biology \& Medicine, v.41, n.7, p.1124-1132, 2006.

HATANAKA, E.; CURI R. Ácidos graxos e cicatrização: uma revisão. Revista Brasileira de Farmácia, v.88, n.2, p.53-58, 2007.

HUANG, Y.; CHENG, Y.; ALEXANDER, K.; DOLLIMORE, D. The thermal analysis study of the drug captopril. Thermochimica Acta, v.367, p.43-58, 2001.

IONASHIRO, M.A.; GIOLITO, I. Nomenclatura, padrões e apresentação dos resultados em análise térmica. Cerâmica, v.26, n.121, p.17-24, 1980. 
IDSON, B. Vitaminas e pele. Cosmetics \& Toiletries, Edição em Português, v.6, p.59-68, 1994.

IDSON, B. Efeitos emulsificantes sobre a pele. Cosmetics \& Toiletries, Edição em Português, v.9, n.4, p.54-59, 1997.

IP, C.; LISK, D.J. Bioactivity of selenium from Brazil nut for cancer prevention and selenoenziyme maintenance. Nutrition and Cancer, v.21, n.3, p.203-212, 1997.

JORDI, H.C. Separation of long and short chain fatty-acids as naphthacyl and substituted phenacyl esters by high-performance liquid-chromatography. Journal of Liquid Chromatography, v.1, n.2, p.215-230, 1978.

JUNQUEIRA, L.C.; CARNEIRO, J. Histologia básica. 7.ed. Rio de Janeiro: Guanabara Koogan, 1990. p.272-280.

SAHOTA, R.S.; KHALEDI, M.G. Nonaqueous capillary electrophoresis. Analytical Chemistry, v.66, n.7, p.1141-1146, 1994.

KARLESKIND, A. Oils and fats: manual. Paris: Lavoisier, 1996. v.2, p.1432-1572.

KARTAL, M.L.C. Method for the analysis of paracetamol, caffeine and codeine phosphate in pharmaceutical preparations. Journal of Pharmaceutical and Biomedical Analysis, v.26, p.857-864, 2001.

KAWASAKI, H.; MAEDA, N.; YUKI, H. Chemiluminescence detection of free fattyacids by high-performance liquid-chromatography with immobilized enzymes. Journal of Chromatography, v.516, n.2, p.450-455, 1990.

KIM, H.H.; CHO, S.; LEE, S.; KIM, K.H.; CHO, K.H.; EUN, H.C.; CHUNG, J.H. Photoprotective and anti-skin-aging effects of eicosapentaenoic acid in human skin in vivo. Journal of Lipid Research, v.47, n.5, p.921-930, 2006.

KING, J.W.; ADAMS, E.C.; BIDLINGMEYER, B.A. Determination of free fatty-acids in natural oils and alkyd resins by high-performance liquid-chromatography. Journal of Liquid Chromatography, v.5, n.2, p.275-304, 1982.

KLEIN, K. Formulando emulsões cosméticas: um guia para principiantes. Cosmetics \& Toiletries, Edição em Português, v.17, p.68-69, 2005.

LAM, S.; GRUSHKA, E. Labeling of fatty-acids with 4-bromomethyl-7-methoxycoumarin via crown ether catalyst for fluorimetric detection in high-performance liquid-chromatography. Journal of Chromatography, v.158, p.207-214, 1978.

LEITE, F. Validação em análise química. 3.ed. Campinas: Átomo, 1998.

LEITE, F. Validação em análise química. 4.ed. Campinas: Átomo, 2002.

LIBARDI, F.S. Lactato de amônio. Cosmetics \& Toiletries, Edição em Português, v.11, n.4, p.50-53, 1999.

LORENZZI, H. Árvores brasileiras. São Paulo: Plantarum., p. 133, 1992. 
MACHADO, L.D.B.; MATOS, J.R. Análise térmica diferencial e calorimetria exploratória diferencial. In: CANEVAROLO Jr., S.V., ed. Técnicas de caracterização de polímeros. São Paulo: Artliber, p.229-261, 2004

MAIMOM, D. Estudo de mercado de matéria-prima: corantes naturais (cosméticos, indústria de alimentos), conservantes e aromatizantes, bio-inseticidas e óleos vegetais e essenciais (cosméticos e oleoquímica). Belém, 2000. (Projeto BRA/96/025 - SUDAM/PNUD).

MAINIERI, C.; CHIMELO, J.P. Fichas de características das madeiras brasileiras. São Paulo. Instituto de Pesquisas Tecnológicas, p.125-126, 1989.

MALZ, F.; JANCKE, H. Validation of quantitative NMR. Journal of Pharmaceutical and Biomedical Analysis, v.38, n.5, p.813-823, 2005.

MARTINI, M.C. Introducion a la dermofarmácia y a la cosmetologia. Zaragoza: Acribia, p. 329, 2005.

MARTINS, S. Bioquímica e fisiologia da pele humana aplicados no desenvolvimento de formulações cosméticas. São Paulo: Racine Cosmetologia Express, 2003. v.4, p.62-100. [Apostila].

MATOS, J.R.; MACHADO, L.D.B. Análise térmica termogravimetria. In: CANEVAROLO Jr., S.V., ed. Técnicas de caracterização de polímeros. São Paulo: Artliber, p.209-228, 2004.

MELO, M.D.O.M.; MANCINI FILHO, J. Antioxidantes naturais da castanha do Brasil (bertholletia excelsa, h b r). Ciência e Tecnologia de Alimentos, v.11, n.2, p.252263, 1991.

BRASIL. Ministério da Saúde. Manual de condutas para úlceras neurotróficas e traumáticas. Brasília, 2002. (Série J. Cadernos de Reabilitação em Hanseníase, n.2).

MITLAG, M.; ARNEJO, N.A.; CARBALLO, O.P.; BLANCO, A.F. Emolientes lipofílicos: predição de funcionalidade através de parâmetros físicos. Cosmetics \& Toiletries, Edição em Português, v.4, n.2, p.45-50, 1992.

MIWA, H.; YAMAMOTO, M.; NISHIDA, T.; NUNOI, K.; KIKUCHI, M. Highperformance liquid-chromatographic analysis of serum long-chain fatty-acids by direct derivatization method. Journal of Chromatography: Biomedical Applications, v.416, n.2, p.237-245, 1987.

MORAES, E.P. Hidrólise de castanha-do-Pará, aveia e trigo com resina de troca catiônica e determinação de aminoácidos, ácidos graxos e sacarídeos utilizando eletroforese capilar. São Paulo, 2004. Tese de Mestrado - Instituto de Química - Universidade de São Paulo.

MORETTO, E.; FETT, R. Tecnologia de óleos e gorduras vegetais na indústria de alimentos. São Paulo: Livraria Varela, 1998.

MORETTO, E.; FETT, R. Óleos e gorduras vegetais: processamento e análises. Florianópolis: UFSC, 1989. 
NASCIMENTO, T.G.; MELO, S.B.F.M.; QUEIROZ, L.O.M.; SILVA, P.F.; BARBOSA, C.V.; PROCÓPIO, J.V.V.; SOUZA, F.S.; MACEDO, R.O. Thermal caracterization and kinetic of evaporation of some types of cosmetics creams using TG and DSC. In: CONGRESSO BRASILEIRO DE ANÁLISE TÉRMICA E CALORIMETRIA, 5., Poços de Caldas, 2006. Livro de resumos. Poços de Caldas: ABRATEC, p. 386, 2006b.

NASCIMENTO, T.G.; MIRANDA, E.O.; BISPO Jr., W.; PROFÍRIO, Z.; PROCÓPIO, J.V.V.; MACEDO, R.O. Thermal Studies of the cosmetics formulations containing active extract of red própolis by menans TG and DSC- Photovisual. In: CONGRESSO BRASILEIRO DE ANÁLISE TÉRMICA E CALORIMETRIA, 5., Poços De Caldas, 2006. Livro De Resumos. Poços De Caldas: ABRATEC, p. 387, 2006c.

NISHIYAMA-NARUKE, A.; SOUSA, J.A.A.; CARNELÓS FILHO, M.; CURI, R. HPLC determination of underivatized fatty acid saponified at low temperature analysis of fatty acids in oils and tissues. Analytical Letters, v.31, p.2565-2576, 1998.

OLIVEIRA, M.A.L. Análise de ácidos graxos em óleos e gorduras por eletroforese capilar. São Paulo, p. 239, 2003. Tese de Doutorado - Instituto de Química - Universidade de São Paulo.

OLIVEIRA, M.A.L.; SOLIS, V.E.S.; GIOIELLI, L.A.; POLAKIEWICZ, B.; TAVARES, M.F.M. Method development for the analysis of trans-fatty acids in hydrogenated oils by capillary electrophoresis. Electrophoresis, v.24, p.1641-1647, 2003.

OLIVEIRA, M.A.L.; MICKE, G.A.; BRUNS, R.E.; TAVARES, M.F.M. Factorial design of electrolyte systems for the separation of fatty acids by capillary electrophoresis. Journal of Chromatography, A, v.924, n.1/2, p.533-539, 2001.

OLIVEIRA, R.V.M. Avaliação in vitro de óleos brasileiros promotores de penetração cutânea do 5 - hidroxi - 2 - (hidroximetil) - 4 pirona - (ácido kójico). São Paulo, p. 295, 2004. Tese de Doutorado - Faculdade de Ciências Farmacêuticas - Universidade de São Paulo.

O'SHEA, M.; BASSAGANYA-RIERA, J.; MOHEDE, I.C. Immunomodulatory properties of conjugated linoleic acid. American Journal of Clinical Nutrition, v.79, n.6, p.1199S-1206S, 2004. [Workshop on the Role of Conjugated Linoleic Acid in Human Health, Winnipeg, Canada, Mar 13-15, 2003.

PAEPE, K.; ROSEEUW, D.; ROGIERS, V. Repair of acetone and sodium lauryl sulphate-damaged human skin barrier function using topically applied emulsions containing barrier lipids. Journal of the European Academy of Dermatology \& Venereology, v.16, n.6, p.587-594, 2002.

PALMA, E.J.; CICHELLO, M.S.F.; PAVANELLI, A.P. Emulsificantes em panificação. In: Oxiteno, 2004. (Art.AL001 - 06/04). Disponível em: http://www.oxiteno.com.br/aplicacoes/mercados/doc/documento.asp?artigotecnico=1 \&segmento=0100\&idioma=PO\& $r=$. pdf. Acesso em: 08/04/2008.

PERMAL, V.L.; TAMBURIC, S.; CRAIG, D.Q.M. Characterisation of the variation in the physical properties of commercial creams using thermogravimetric analysis and rheology. International Journal of Pharmaceutics. v.155, p.91-98, 1997. 
PERRETT, D. Capillary electrophoresis for drug analysis. In: MOFFAT, A.C.; OSSELTON, M.D.; WIDDOP, B., eds. Clarke's analysis of drugs and poisons. S.I.: Pharmaceutical Press, v.1, 30, p.535-549, 2003.

PICÓ, Y; RODRIGUEZ, R.; MAÑES, J. Capillary electrophoresis for determination of pesticide residues. Trends in Analytical Chemistry, v.22, n.3, p.133-151, 2003.

RIBEIRO, C.J. Cosmetologia aplicada a dermoestética. São Paulo: Pharmabooks, 2006.

RILEY, R.T.; NORRED, W.P.; WANG, E.; MERRILL, A.H. Alteration in sphingolipid metabolism: bioassays for fumonisin- and ISP-I-like activity in tissues, cells and other matrices. Natural Toxins, v.7, n.6, p.407-414, 1999.

ROBERT, L. O envelhecimento. Lisboa: Instituto Piaget, p.21-330, 1994.

ROCHE, H.M. Unsaturated fatty acids. Proceedings Nutrition Society, v.58, n.2, p.397-401, 1999.

ROLDAN-ASSAD, R.; GAREIL, P. Capillary zone electrophoretic determination of c2-c-18 linear saturated free fatty-acids with indirect absorbency detection. Journal of Chromatography, A, v.708, n.2, p.339-350, 1995.

ROSE, D.P.; CONNOLLY, J.M. Omega-3 fatty acids as cancer chemopreventive agents. Pharmacology \& Therapeutics, v.83, p.217-244, 1999.

RYAN, E.; GALVIN, K.; O'CONNOR, T.P.; MAGUIRE, A.R.; O'BRIEN, N.M. Fatty acid profile, tocopherol, squalene and phytosterol content of brazil, pecan, pine, pistachio and cashew nuts. International Journal of Food Sciences and Nutrition, 57, n.3/4, p.219-228, 2006.

RUBIN, J. La proteccion solar. In: VIGLIOGLIA, A.; RUBIN, J. Cosmiatria III. Buenos Aires: A.P. Americana, p.38-47, 1997.

SAKODYNSKY, K.I.; SMOLYANINOV, G.A.; ZELVENSKY, V.Y.; GLOTOVA, N.A. Gas-chromatography of underivatized fatty-acids on polyethylene-glycol stationary phases. Journal of Chromatography, v.172, p.93-105, 1979.

SANCTIS, D.S. Emulsões: aplicações em cremes e loções cosméticas. In: Oxiteno. 2004. em: http://www.oxiteno.com.br/aplicacoes/mercados/doc/documento.asp?artigotecnico=3 3\&segme. Acesso em: 10/04/2007.

SANTORO, M.I.R.M.; SILVA, F.C.F.; KEDOR-HACKMAN, R.M.; RAMOS, R.R.; MERCURI, L.P.; MATOS, J.R. Stability analysis of emulsions containing UV and IR filters. Cosmet. Toiletries, v.115, n.12, p.55-62, 2000.

SCOTTI, L. Estudo do envelhecimento cutâneo e da eficácia cosmética de substâncias ativas empregadas em combatê-lo. São Paulo, p.162, 2002. Tese de Mestrado - Faculdade de Ciências Farmacêuticas - Universidade de São Paulo.

SHABIR, G.A. Validation of high-performance liquid chromatography methods for pharmaceutical analysis: understanding the differences and similarities between validation requirements of the US Food and Drug Administration, the US 
Pharmacopeia and the International Conference on Harmonization. Journal Chromatography A, v.987, p.57-66, 2003.

SHIN, H.S.; KIM, S.; MYUNG, S.W.; PARK, J.S. lodoacetonitrile and bromoacetonitrile as alkylating reagents for the nitrogen phosphorus detector. Analtical Chemistry, v.67, n.11, 1853-1859, 1995.

SILVA, E.C.; SOARES, I.C. Tecnologia de emulsões. Cosmetics \& Toiletries, Edição em Português, v.8, p.37-45, 1996.

SILVA, J.A.F.D.; COLTRO, W.K.T.; CARRILHO, E.; TAVARES, M.F.M. Terminologia para as técnicas analíticas de eletromigração em capilares. Química Nova, v.30, n.3, p.740-744. 2007.

SILVA, M.V. Determinação do EHL crítico do óleo de babaçu, avaliação da função hidratante e aplicação em emulsões tópicas como novo adjuvante lipofílico. Recife-PE, p.88, 1997. Dissertação de Mestrado - Ciências Farmacêuticas - Universidade Federal de Pernanbuco.

SIMS, R.J.; FIORITI, J.A. In: FURIA, T.E., ed. CRC Handbook of Food Additives. 2.ed. Boca Raton: CRC Press, v.2, p.13, 1980.

SOLIS, V.E.S. Modificações no óleo da castanha do Pará (Bertholletia excelsa). São Paulo, p. 105, 2001. Tese de Doutorado - Faculdade de Ciências Farmacêuticas - Universidade de São Paulo.

SOLIS, V.S.; GIOIELLI, L.A.; POLAKIEWICZ, B. Hydrogenation and interesterification of Brazil nut oil (Bertholletia excelsa). Grasas y Aceites, v.52, n.3/4, p.192-197, 2001.

STAUFFER, C.E. Fats and oils. St. Paul: Eagan Press, p.47, 1996.

STEINER, D. Envelhecimento cutâneo. Cosm. Toil., v.7, p.29, 1995.

STEINER, D. Hidratação e regeneração da pele. Cosmetics \& Toiletries, Edição em Português, v.13, p.22, 2001.

TAMBURIC, S.; CRAIG, D.Q.M.; VULETA, G.; MILIC, J. A comparison of electrical and rheological techniques for the characterisation of creams. International Journal of Pharmaceutics, v.137, n.28, p.243-248, 1999.

TAVARES, M.F.M. Eletroforese capilar: conceitos básicos. Química Nova, v.19, n.2, p.173-181, 1996.

TAVARES, M.F.M. Mecanismos de separação em eletroforese capilar. Química Nova, v.20, n.5, p.493-511, p.493, 1997.

RUNNSTROM, J.; TISELIUS, A.; VASSEUR, E. Gamones of Psammechinus miliaris and Echinocardium cordatum. Arkiv foer Kemi, Mineralogi och Geologi, v.15A, n.16, p.1-18, 1942.

AMERICAN OIL CHEMISTS' SOCIETY. Official methods and recommended practices of AOCS. Official Method. Ce 2-66, 1998. 
The Lipid Library. Lipid Chemistry, Biology and Analysis. Fatty Acids and Eicosanoids. Disponível em: http://www.lipidlibrary.co.uk/Lipids/fa eic.html. Acesso em: 14/04/2009.

TOMÁS-BARBERÁN, F.A. Capillary electrophoresis: A new technique in the analysis of plant secondary metabolites. Phytochemical Analysis, v.6, n.4, p.177-131, 1995.

TSUYAMA, Y.; UCHIDA, T.; GOTO, T. Analysis of underivatized c-12-c18 fatty-acids by reversed-phase ion-pair high-performance liquid-chromatography with conductivity detection. Journal of Chromatography, v.596, n.2, p.181-184, 1992.

VELASCO, M.V.R.; RIBEIRO, M.E.; STEINER, D.; BEDIN, V.; OKUBO, F.R. Rejuvenescimento da pele por peeling químico: enfoque no peeling de fenol. Anais Brasileiros de Dermatologia, v.79, n.1, p.91-99, 2004.

VENKATACHALAM, M.; SATHE, S.K. Chemical Composition of Selected Edible Nut Seeds, Journal of Agricultural and Food Chemistry, v.54, p.470, 2006.

VERLENGIA, R.; GORJAO, R.; KANUNFRE, C.C.; BORDIN, S.; LIMA, T.M.; NEWSHOLME, P. CURI, R. Genes Regulated by Arachidonic and Oleic Acid in Raji Cells. Lipids, v.38, n.11, p.1157-1165, 2003.

WENDLANDT, W.W. Thermal analysis. 3.ed. New York: John Wiley, p. 814, 1986. (Chemical Analysis, 19).

WESTON, A.; BROWN, P.R. HPLC and CG: principles and practice. San Diego: Academic Press, p.280, 1997.

WOLF, J.H.; KORF, J. 4-Bromomethyl-7-methoxycoumarin and analogues as derivatization agents for high-performance liquid chromatography determinations: a review. Journal of Pharmaceutical \& Biomedical Analysis, v.10, n.213, p.99-107, 1992.

WOLFF, R.L.; FABIEN, R.J. The use of isopropanol for fat extraction from dairyproducts and for the subsequent esterification of fatty-acids. Lait, v.69, n.1, p.33-46, 1989.

WENDLANDT, W.W. Thermal analysis. 3.ed. New York: John Wiley, p.1, 1986. [Chemical analysis, v.19].

YEUNG, E.S. Optical-detectors for capillary electrophoresis. Advances in Chromatography, v.35, p.1-51, 1995.

YOO, J.S.; MCGUFFIN, V.L. Determination of fatty-acids in fish oil dietarysupplements by capillary liquid-chromatography with laser-induced fluorescence detection. Journal of Chromatography, v.627, n.1/2, p.87-96, 1992.

DERMATOLOGIA.NET. Estética. Envelhecimento cutâneo. Disponível em: http://www.dermatologia.net/neo/base/estetica/est fotoenv.htm. Acesso em: 20/05/2008.

CRODA. Disponível em: http://www.croda.com.br/. Acesso em: 19 out. 2006. 
EMBRAPA.

http://sistemasdeproducao.cnptia.embrapa.br/FontesHTML/Castanha/CultivodaCasta nhadoBrasilRO/bibliografia.htm. Acesso em: 08/06/2008.

SANTORO, M.M.I.; PRADO, M.S.A.; STEPPE, M.; KEDOR-HAKMANN, E.R.M. Eletroforese capilar: teoria e aplicações na análise de medicamentos. Revista Brasileira de Ciências Farmacêuticas, v.36, n.1, p.97-110, 2000.

UNITED States Pharmacopeia. 25.ed. Rockville: United States Pharmacopeial Convention, 2002. p.1534-1535.

VEUTHEY, J.L. Capillary electroforesis in pharmaceutical and biomedical analysis. Analytical and Bioanalytical Chemistry, v.381, n.1, p.93-95, 2005.

VOIGT, R. Tratado de tecnologia farmacêutica. 3.ed. Zaragoza: Acribia, 1982.

WATSON, D.G. Pharmaceutical analysis: a textbook for pharmacy students and pharmaceutical chemist. Toronto: Churchill Livingstone, 1999. p.293-300. 